\title{
Identification of molecular role of Pelota protein in proliferation and differentiation of male germ stem cells by analysis of conditional knock-out mice
}

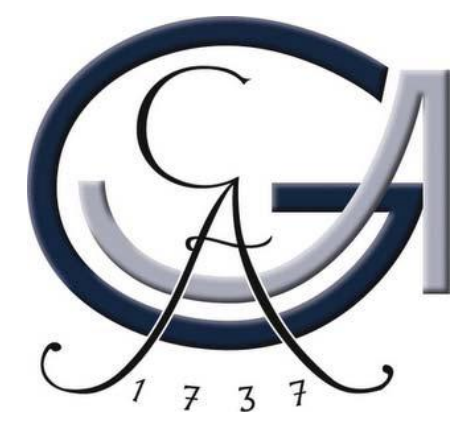

\section{DISSERTATION}

to obtain the $\mathrm{Ph}$. $\mathrm{D}$. degree in the

International Ph.D. Program for Agricultural Sciences in Göttingen (IPAG) at the Faculty of Agricultural Sciences,

Georg-August-University Göttingen, Germany

Presented by

Priyadharsini Raju

Born in TamilNadu, India

Göttingen, 2015 
D7

Name of supervisor: $\quad$ Prof. Dr. Dr. Bertram Brenig

Name of Co-supervisor: $\quad$ Prof. Dr. Ibrahim M. Adham

Date of dissertation: $\quad 21.05 .2015$ 


\section{Table of contents}

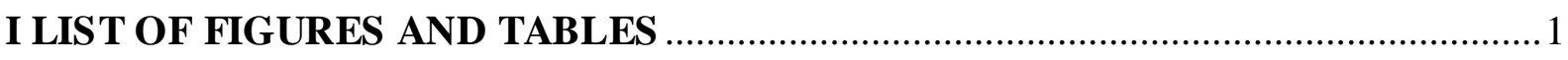

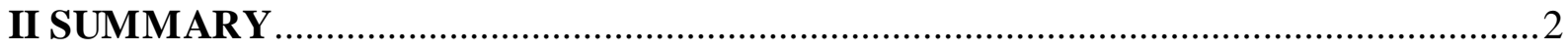

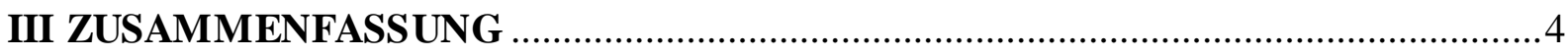

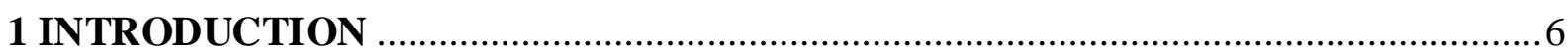

1.1 PELO protein:structure, localization and expression ................................................6

1.1.2 The biological role of Pelo and its homolog in yeast, Dom 34 ...................................6

1.2.1 Dom34/Pelo is indispensable for the cell division in yeast .........................................6

1.2.2 Pelo deletion impairs meiotic cell division causing male infertility in Drosophila .......... 7

1.2.3 Pelo deletion impairs the self-renewal of germ line stem cells (GSCs) in female

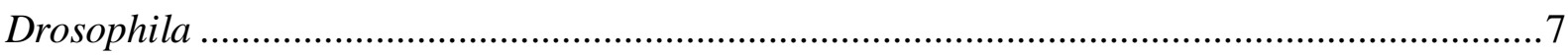

1.2.4 Pelo is essential for early embryonic development in mouse ...................................... 8

1.2.5 Dom34 and its interacting proteins are involved in RNA quality control mechanism

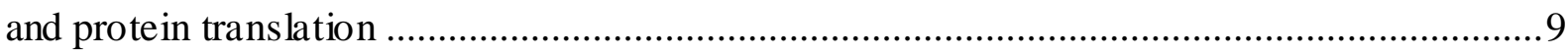

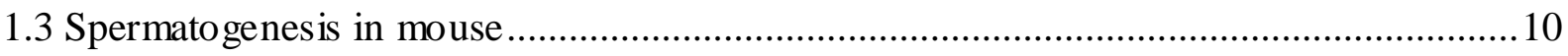

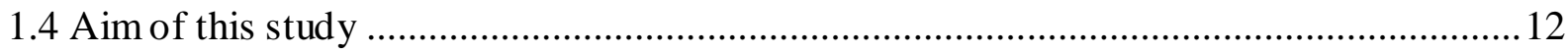

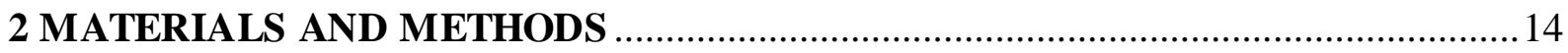

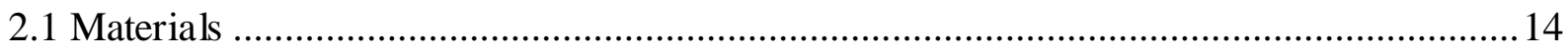

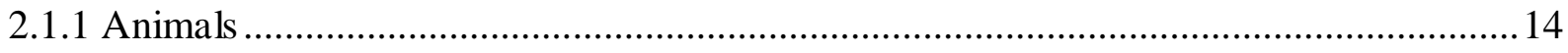

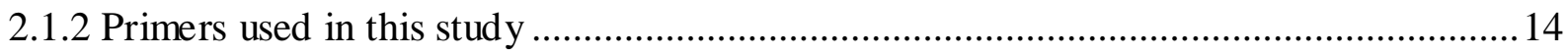

2.1.3 Sterilizations of solutions and equipments ........................................................ 15

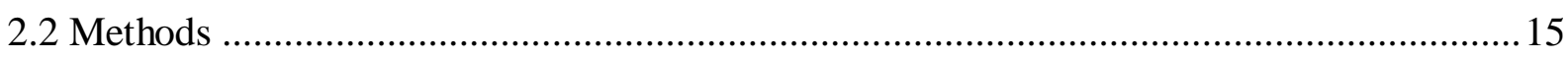

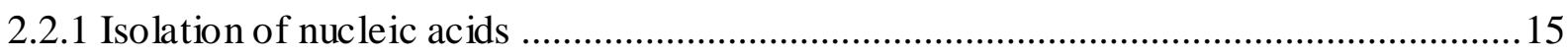

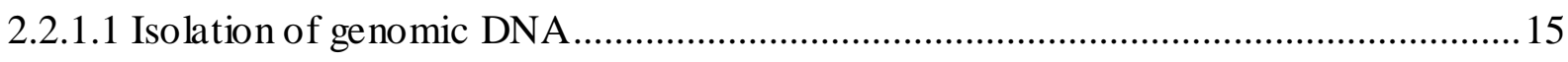

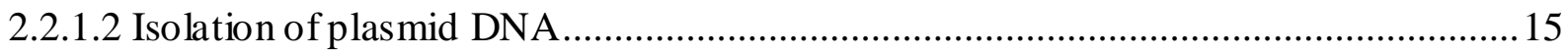

2.2.1.3 Isolation of DNA fragments after agarose gel electrophoresis ................................. 16

2.2.2 Plasmid DNA transformation into competent bacteria ............................................. 16 


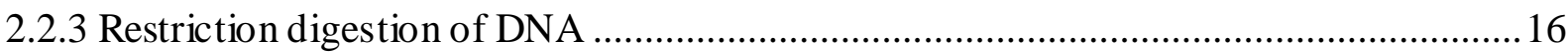

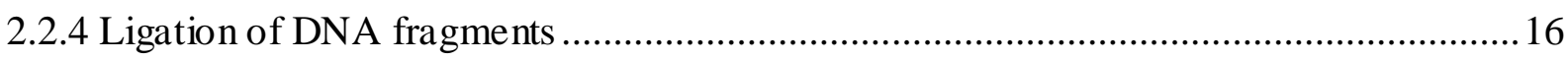

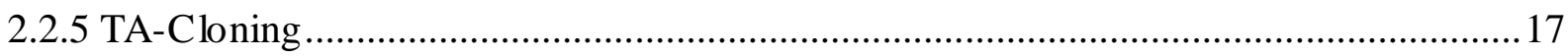

2.2.6 Isolation of total RNA, cDNA synthesis, RT-PCR and quantitative real time PCR .......17

2.2.7 Protein extraction and Western blotting .............................................................. 18

2.2.7.1 Preparation of nuclear and cytoplasmic protein fractions ........................................ 19

2.2.8 Histological and immunocytochemical analysis ...................................................... 19

2.2.8.1 Tissue collection and preparation for paraffin embedding ......................................19

2.2.8.2 Haemotoxylin and Eosin staining of mouse testis ................................................ 19

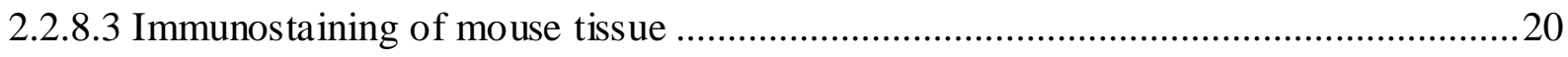

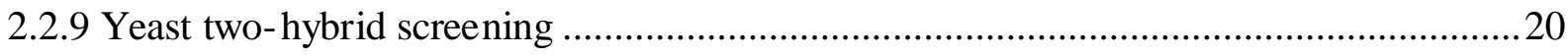

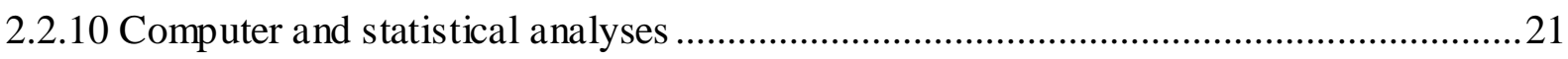

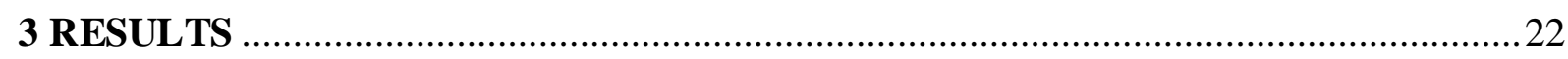

3.1 Pelota mediates gonocyte maturation and maintenance of spermatogonial stem cells in

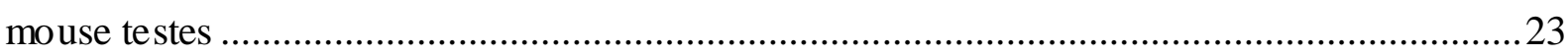

3.2. Pelota regulates the development of extraembryonic endoderm through activation of

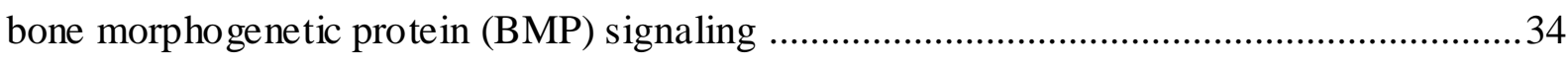

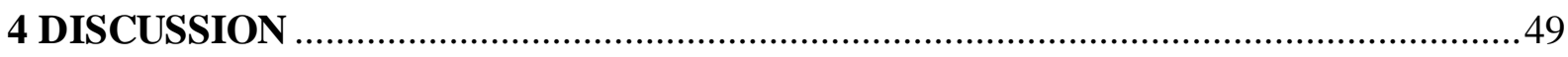

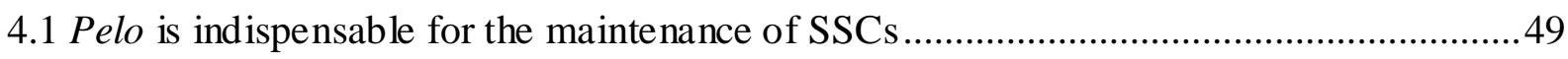

4.2 Regulation of cell cycle in Pelo deleted germ cells........................................................52

4.3 Consequences of Pelo over-expression on male germ cells ...........................................53

4.4 Pelo deficiency attenuates transcriptional activity of FOXO1 through enhanced

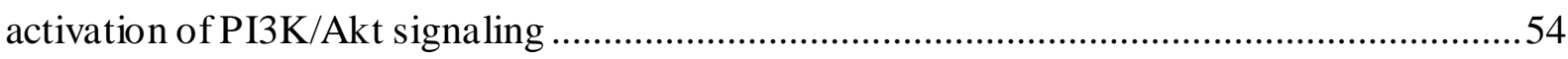

4.5 Attenuation of BMP signaling in Pelo-deficient ESC impairs the development of

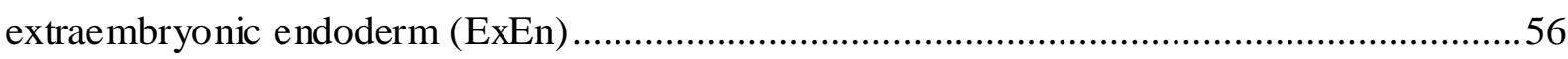

4.6 Identification of molecular role of Pelo in mammalian system ......................................58

4.7 Identification of PELO interacting proteins by yeast two-hybrid screening .....................58 
4.8 Predicted functions of the interaction of Pelo and selected interacting proteins

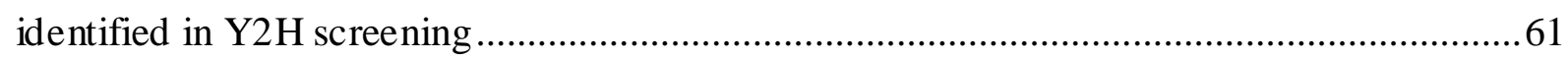

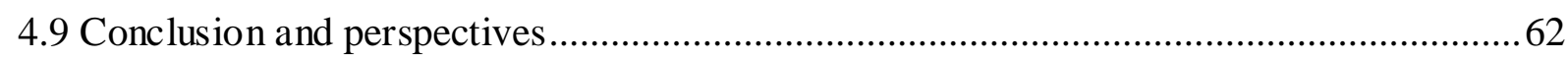

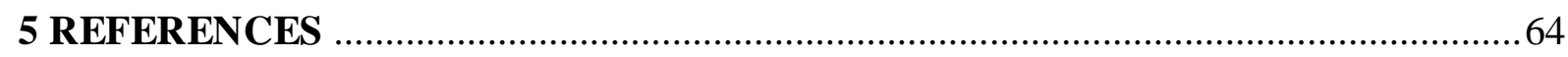

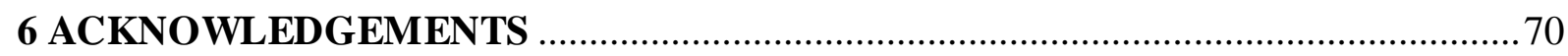

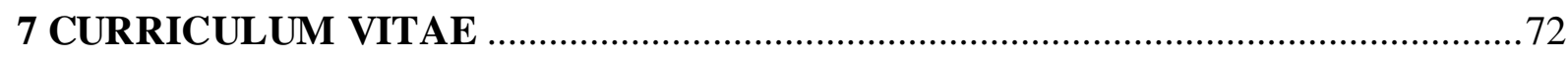

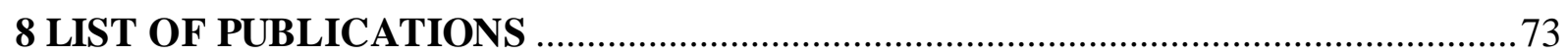




\section{LIST OF FIGURES AND TABLES}

Figure 1.1 Sagittal section of a Drosophila germarium 8

Figure 1.2 Schematic illustration of the germ cell development 10

$\begin{array}{llr}\text { Figure 1.3 Spermatogenesis in mouse } & 12\end{array}$

Figure 4.1 Cell cycle analysis of PELO depleted germ cells 53

Figure 4.2 Consequence of Pelo over-expression on male germ cells 54

Figure 4.3 Schematic illustration of PI3K/Akt signaling pathway 56

Figure 4.4 Identification of PELO interaction proteins by Y2H screening of 59 ESC library

Figure 4.5 Direct $\mathrm{Y} 2 \mathrm{H}$ to confirm the interaction of identified proteins that 60 interact with Pelo

Table 4.1 Genes that are involved in the regulation of SSCs 51

Table 4.2 Summary of putative interaction proteins of PELO identified by 60 direct $\mathrm{Y} 2 \mathrm{H}$ screening 


\section{SUMMARY}

Pelota (Pelo) is an evolutionally conserved gene, which has been characterized in various species. In Drosophila, Pelo deficiency affects both male and female fertility. The molecular function of PELO has been extensively characterized in yeast, where PELO ortholog Dom34 and its interacting partner $\mathrm{Hbsl}$ participate in RNA quality control mechanism named No-Go decay (NGD). In mice, genetic ablation of Pelo leads to embryonic lethality at the early implantation stage as a result of the impaired development of extra-embryonic endoderm (ExEn). The in vitro culture of Pelo-null blastocysts revealed that PELO may have a role in the regulation of the cell cycle or the self-renewal of a pluripotent inner cell mass (ICM) or embryonic stem cells (ESCs).

The overall aim of this study was to investigate the role of Pelo on male germ cell development. To define the consequences of Pelo deletion on male germ cells, we temporally deleted the gene at both embryonic and postnatal stages. Deletion of Pelo in adult mice resulted in a complete loss of whole germ cell lineages after 45 days of deletion. The absence of newly emerging spermatogenic cycles in mutants confirmed that spermatogonial stem cells (SSCs) were unable to maintain spermatogenesis in the absence of PELO. However, germ cells beyond the undifferentiated SSC stage were capable of completing spermatogenesis and producing spermatozoa, even in the absence of PELO. The spermatozoa lacking Pelo were also capable of fertilizing oocytes.

Following the deletion of Pelo during embryonic development, we found that PELO is dispensable for maintaining gonocytes. However, embryonic depletion of Pelo disrupts the transition of gonocytes to SSCs. Immunohistological and protein analyses revealed the attenuation of FOXO1 transcriptional activity, which induces the expression of many SSC self-renewal genes. These results indicate that the role of Pelo in SSC maintenance is mediated through the activation of the FOXO1. The decreased transcriptional activity of FOXO1 in mutant testes was due to enhanced activity of the PI3K/Akt signaling pathway, which led to phosphorylation and cytoplasmic sequestration of FOXO1. The inactivation of FOXO1 in the Pelo mutants resulted in the failure of establishment of SSCs in the postnatal life. These results suggest that PELO negatively regulates the PI3K/Akt pathway and that the enhanced activity of PI3K/Akt and subsequent FOXO1 inhibition are responsible for the impaired development of SSCs in mutant testes. Taken together, our study has revealed the indispensable role of Pelo in male fertility and also identified the molecular pathway that is 
responsible for the male infertility from Pelo deletion. Further to identify the putative role of Pelo in mammals we identified the interacting proteins of PELO by yeast two-hybrid (Y2H) screening of ESC cDNA library. We have identified ribosomal protein, RACK1 and elongation factor 2 as interactional partners of PELO through direct $\mathrm{Y} 2 \mathrm{H}$.

In the second part of the study, we found that Pelo is dispensable for the self-renewal of ESCs but is essential for the differentiation into extra embryonic endoderm (ExEn). At molecular level, our observations showed alterations in expression of components of the bone morphogenetic protein (BMP) signaling pathway. To further verify the attenuated activity of BMP signaling in Pelo-null cells, we have established a BMP responsive reporter cell line $\left(\right.$ Pelo $^{F /-}$ BRE-FFLuc). The relative FFLuc activity in control cells was significantly higher than that of mutant cells after the treatment with BMP. Collectively, the results of this study further confirmed that the mutant $\mathrm{Pelo}^{\Delta /-}$ EBs produced extracellular modulators of BMP signaling activity. 


\section{ZUSAMMENFASSUNG}

Pelota (Pelo) ist ein evolutionär konserviertes Gen, das bereits in verschiedenen Spezies identifiziert und charakterisiert worden ist. In Drosophila hat die Defizienz Ausfall von Pelo einen Effekt auf die Fertilität beider Geschlechter. Die molekulare Funktion von PELO wurde umfangreich in Hefen untersucht. Hier wurden das PELO-Ortholog Dom34 und sein Interaktionspartner $\mathrm{Hbsl}$ als mitwirkende proteine des RNA-Kontrollmechanismus „No-Go decay“ (NGD) identifiziert. In Mäusen führt die Deletion von Pelo in der frühen Implantationsphase zu einer gestörten Entwicklung des extraembryonalen Endoderms (ExEn) und folglich zu embryonaler Letalität. Ergebnisse aus Versuchen mit in vitro Kulturen von Pelo-defizienten Blastozysten führen zudem zu der Annahme, dass PELO eine Rolle in der Regulation des Zellzyklus oder bei der Selbsterneuerung der pluripotenten inneren Zellmasse bzw. embryonalen Stammzellen spielen könnte.

Das Ziel dieser Studie ist es, die Rolle von Pelo in der männlichen Keimzellentwicklung zu untersuchen. Um zu überprüfen, welche Konsequenzen die Deletion von Pelo auf die männlichen Keimzellen hat, wurde das Gen konditional auf embryonaler und postnataler Ebene deletiert. In adulten Mäusen führte die Deletion von Pelo nach 45 Tagen zu einem vollständigen Verlust der gesamten Keimzellen. Das Ausbleiben von neu entstehenden, spermatogonialen Zyklen in Mutanten führte $\mathrm{zu}$ der Annahme, dass spermatogoniale Stammzellen (SSCs) in Abwesenheit von PELO nicht in der Lage waren, die Spermatogenese aufrecht zu erhalten. Im Gegensatz dazu konnten Keimzellen außerhalb der undifferenzierten SSC-Ebene auch ohne PELO die Spermatogenese komplett durchlaufen und Spermatozoen produzieren. Darüber hinaus sind Pelo-defiziente Spermatozoen auch in der Lage, Oozyten zu befruchten.

Weitere Versuche haben zu dem Ergebnis geführt, dass die Deletion von PELO während der embryonalen Entwicklung keinen Effekt auf die Erhaltung von Gonozyten hat, jedoch den Übergang von Gonozyten zu spermatogonialen Stammzellen stört. Immunhistologische und proteinbiochemische Analysen zeigten eine abgeschwächt transkriptionelle Aktivität des FOXO1, das die Expression von Genen zur Selbsterneuerung der SSCs induziert. Diese Ergebnisse weisen darauf hin, dass die Rolle von Pelo in der Aufrechterhaltung der SSCs durch die Aktivierung von FOXO1 vermittelt wird. 
Die verminderte transkriptionelle Aktivität des FOXO1 in Hoden von Pelo-defizienten Mäusen lässt sich auf die gesteigerte Aktivität des PI3K/AKT-Signalweges zurückführen, der zur Phosphorylierung und lokalisierung des FOXO1 ins Cytoplasma führt. Die Inaktivierung von FOXO1 führt zu einem Defekt in der Etablierung von spermatogonialen Stammzellen auf postnataler Ebene in Pelo-defizienten Mäusen. Diese Ergebnisse lassen vermuten, dass PELO den PI3K-AKT-Signalweg negativ reguliert und die gesteigerte Aktivität von PI3K/AKT sowie die daraus resultierende Hemmung des FOXO1 verantwortlich für die gestörte Entwicklung der SSCs in Pelo-defizienten Hoden sind. Zusammenfassend hat die Studie gezeigt, dass PELO für die männliche Fertilität unentbehrlich ist. Darüber hinaus wurde der Signalweg identifiziert, der für die männliche Unfruchtbarkeit in Pelo-defizienten Mäusen verantwortlich ist. Um die mutmaßliche Rolle von Pelo in Säugetieren zu identifizieren, wurden die Interaktionspartner von PELO mittels eines „Yeast-2-Hybrid Screenings“ einer embryonalen Stammzell cDNA-Bibliothek ermittelt. Als Interaktionspartner von PELO wurden das ribosomale Protein, RACK1 und der Elongationsfaktor 2 identifiziert.

Im zweiten Teil der Arbeit konnte gezeigt werden, dass Pelo entbehrlich für die Selbsterneuerung der embryonalen Stammzellen ist, jedoch eine essentielle Rolle bei der Differenzierung des extraembryonalen Endoderms (ExEn) spielt. Auf molekularer Ebene wurden Veränderungen in der Expression der Komponenten des Bone morphogenetic protein (BMP)-Signalweges beobachtet. Um die abgeschwächte Aktivität des BMP-Signalweges in Pelo-defizienten Zellen zu überprüfen, wurde eine Reporter-Zelllinie etabliert, die auf BMP reagiert (Pelo ${ }^{F /-}$ BRE-FFLuc). Die relative FFLuc-Aktivität war nach Behandlung mit BMP in Kontrollzellen signifikant höher als in Pelo-defizienten Zellen. Alles in allem bestätigen die Ergebnisse dieser Studie, dass die mutierten $\mathrm{Pelo}^{\Delta /-}$ Embryoidkörper extrazelluläre Modulatoren des BMP-Signalweges produzieren. 


\section{INTRODUCTION}

\subsection{PELO protein: structure, localization and expression}

Pelota (PELO) is an evolutionarily conserved protein, which was identified during a screening for mutations in genes causing male infertility in Drosophila melanogaster (Castrillon et al., 1993). The Pelo homologous gene was cloned and sequenced in several species including archaebacteria, Arabidopsis thaliana, Saccharomyces cerevisiae, Drosophila melanogaster, Caenorhabditis elegans, mouse and human (Bult et al., 1996; Davis and Engebrecht, 1998; Lalo et al., 1994; Ragan et al., 1996; Shamsadin et al., 2002; Shamsadin et al., 2000).

Alignment of PELO protein sequences of Archaebacteria, yeast, Drosophila, A. thaliana, $C$. elegans and human, showed that the proteins are 23, 36, 70, 51, 57 and 95\% identical to murine PELO, respectively. PELO contains a conserved nuclear localization signal and has the eEF1 $\alpha$-like domain at the carboxyl end. The presence of eEF1 $\alpha$-like domain in the primary structure of PELO suggests that PELO is involved in the translation machinery. Expression analyses demonstrated that PELO is widely expressed in human and murine tissues as well as during embryonic development (Shamsadin et al., 2002; Shamsadin et al., 2000). Further studies by Burnika-Turek et al. (2010) showed that PELO is sub-cellularly localized at the actin cytoskeleton and is interacting with several cytoskeleton-associated proteins such as HAX1 and SRPX and translation regulating proteins such as EIF3G. Using bimolecular fluorescence complementation (BiFC) assay, it has been demonstrated that the interaction between Pelo either with HAX1, EIF3G or SRPX occurs in cyto skeletal filaments.

\subsection{The biological role of Pelo and its homolog in yeast, Dom34}

The biological role of PELO has been investigated in various species, revealing the possible role of PELO in cell division, male and female infertility, early embryogenesis, RNA decay machinery, ribosomal recycling and protein translation.

\subsubsection{Dom 34/Pelo is indispensable for the cell division in yeast}

Dom34 is a Pelo homolog in S. cerevisiae, which was isolated in a screen for mutant strains with meiotic failure. Dom 34 mutants fail to undergo sporulation properly, exhibit a G1 delay as well as fail to correctly execute pseudohyphal development (Davis and Engebrecht, 1998). Analysis of mitotic and meiotic divisions in the Dom34 mutants revealed that the mitotic 
division in Dom34 mutants exhibits a $\mathrm{G}_{1}$ delay, while the meiotic division occurs too rapid and produces fewer spores compared to wild type. The yeast mutants also fail to segregate chromosomes properly (Davis and Engebrecht, 1998). Introduction of Pelo gene of Drosophila into yeast strain with Dom34 mutant provides substantial rescue of the Dom34 growth defects indicating a conserved function of PELO (Eberhart and Wasserman, 1995).

\subsubsection{Pelo deletion impairs meiotic cell division causing male infertility in Drosophila}

In Drosophila, mutations in Pelo gene disrupt spermatogenesis. Cytological analysis of spermatogenesis in homozygous mutant males revealed normal mitotic division, but the cell cycle of meiotic division is arrested at $\mathrm{G} 2 / \mathrm{M}$ transition phase of first meiotic division (Eberhart and Wassermann, 1995). Nevertheless, the other aspects of spermatogenesis continue, resulting in $4 \mathrm{~N}$ like spermatozoa. In arrested spermatocytes, it was found that the chromosomes partially condense but never move away from the nuclear periphery. There is also a failure in nuclear envelope breakdown. Apart from these two defects, the spindle formation that is essential for centrosome separation and moving towards the pole was absent. Thus, Pelota is required in meiosis for spindle formation and nuclear envelope breakdown but not for chromosome condensation. The continued differentiation of the $4 \mathrm{~N}$ spermatocytes to sperm-like structure suggests that Pelota is required only for the meiotic cell division, but is dispensable for the other aspects of spermatogenesis.

\subsubsection{Pelo deletion impairs the self-renewal of germ line stem cells (GSCs) in female Drosophila}

Homozygous mutant females of Drosophila are sub-fertile and exhibit small ovary. The study of Xi et al. (2005) has shown that Pelo regulates self-renewal of GSC in ovary of Drosophila. In D. melanogaster, there are 16 ovarioles per ovary. The most anterior portion of the ovariole contains the germarium, the location of GSCs, terminal filaments and cap cells (Fig. 1.1). The somatic cells (cap cells) in the anterior tip of germarium regulate the self-renewal of GSC by secreting different growth factors. The cap cells secrete the BMP signals that could only act on the two GSCs located adjacent to them and maintain their self-renewal. But as the GSC gives rise to daughter cells, they migrate further away from the influence of BMP and thereby result in their differentiation. Song et al. (2004) established transgenic flies over-expressing 
$d p p$ which in turn over-expresses dpp/BMP activity in ovary. In transgenic flies overexpressing BMP signal in cap cells, BMP reaches to all resident GSCs in the germarium. Therefore, these cells sustain the self-renewal potential and form GSC-like tumours in the germarium. In a search for mutations that rescue the tumor development in the BMP transgenic flies, it was found that the mutation in Pelo gene overcomes the development of germ-line tumor in the transgenic flies that over-express BMP signal in cap cells (Xie and Spradling, 1998; Song et al., 2004). These findings indicate that Pelo is involved in modulating BMP signaling in GSCs of Drosophila.

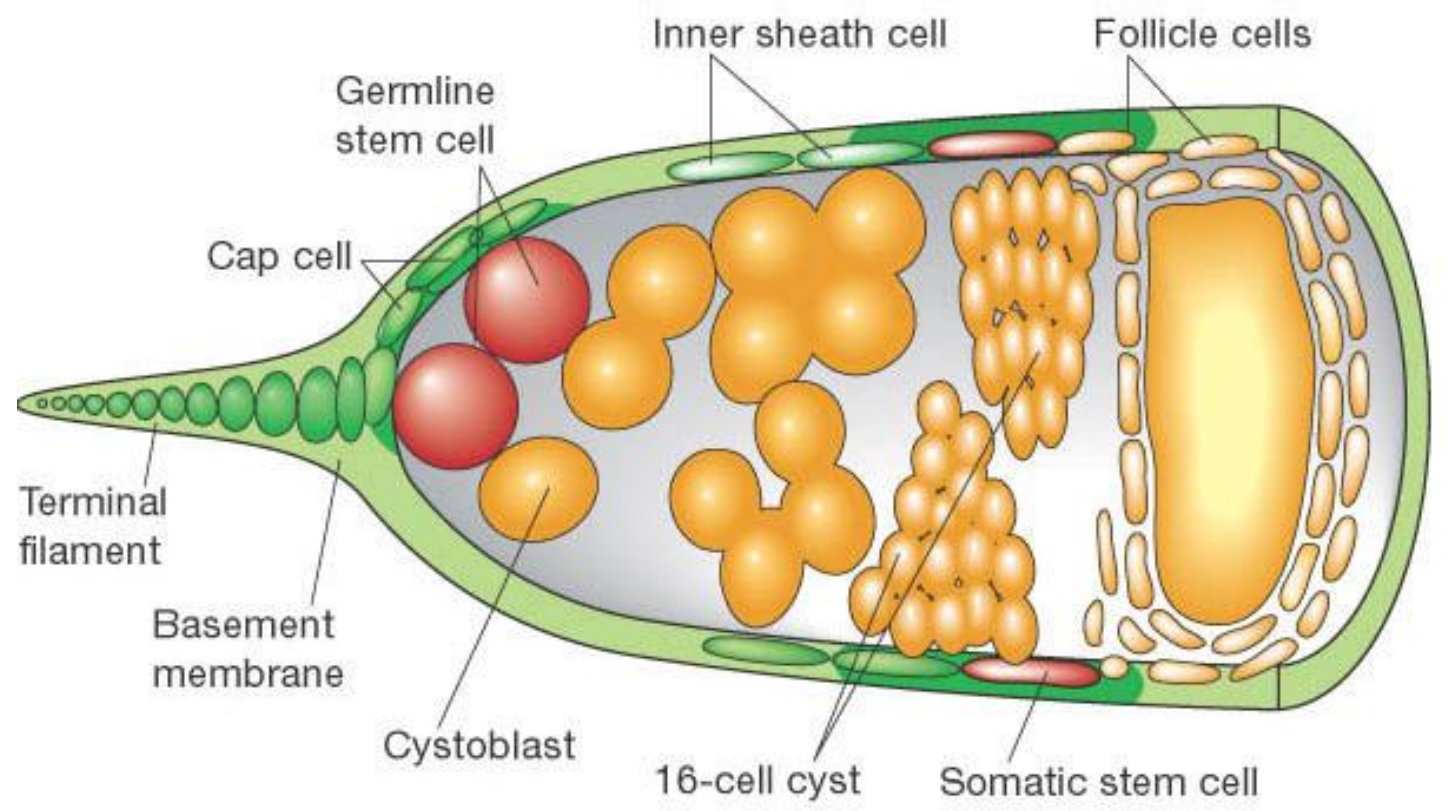

Fig. 1.1 Sagittal section of a Drosophila germarium. Each ovary contains more than a dozen germaria. At the anterior part of germarium there are two germ line stem cells (GSC in red) adjacent to cap cells (green). Each GSC divides to form a cystoblast and another stem cell; the cystoblast undergoes four synchronized divisions with incomplete cytokinesis to form a cyst of 16 interconnected cells. Cysts move down the germarium at the posterior end of the germarium forming the follicle with the oocyte (Adopted from Spradling et al., 2004).

\subsubsection{Pelo is essential for early embryonic development in mouse}

Adham et al. (2003) studied the consequences of Pelo deletion in conventional Pelo knockout mice. Upon deletion of Pelo, heterozygous males and females display no overt phenotype and are fertile, but homozygous animals die at early embryonic development. 
Further analysis revealed that the embryonic development progress es normally in mutant embryos till gastrulation stage, but then embryos die between E6.5 and E7.5. At E7.5, Pelo mutant embryos were abnormally small or entirely resorbed. The differentiation of the three germ layers was initiated in $\mathrm{Pelo}^{-/-}$embryos, which suggests that the developmental failure might be due to proliferation defect. In vitro culture of blastocysts, showed that the inner cell mass (ICM) proliferates normally, hatches from blastocyst and attaches to the culture dish. However, the ICM fails to expand further in culture. The impaired growth of mitotically active ICM and the survival of the trophoblast that is mitotically inactive, suggests that PELO is essential for the normal mitotic division. This was also supported by the higher percentage of aneuploid and polyploid cells in developmentally impaired Pelo null embryos than in the normal littermates. On other hand, it was hypothesized that Pelo-deficient ICM loses its pluripotency and differentiates (Adham et al., 2003).

\subsubsection{Dom34 and its interacting proteins are involved in RNA quality control mechanism and protein translation}

The molecular role of PELO has been studied extensively in yeast. These experiments reveal that PELO participates in RNA quality control mechanisms and ribosomal recycling. Cells have multiple quality control mechanisms that recognize and eliminate defective mRNA during the process of translation. These mechanisms include: 1) No-Go Decay (NGD), that degradates mRNAs containing stalled ribosomes; 2) Non-Stop Decay (NSD), which clears mRNAs lacking a termination codon (Doma and Parker, 2006; Gandhi et al., 2008) and 3) Nonsense-Mediated Decay (NMD), where an mRNA contains an aberrant stop codon inside the open reading frame (Kobayashi et al., 2010). Recent reports showed that Dom34/Pelo are involved in the recycling of ribosomes which are stalled during translation (Doma and Parker, 2006; Passos et al., 2009). Apart from yeast, conserved functions of PELO in quality control mechanisms have been observed in diverse species, such as archaebacteria and Drosophila (Kobayashi et al., 2010; Lee et al., 2007; Passos et al., 2009). Recently it has been also shown that mammalian Pelo-Hbsl complex is involved in the decay of non-stop mRNA in HeLa cells (Saito et al., 2013). A role for Dom34 in translation is also suggested by a presence of eRF1-like domain similar to that of ERF1, which is involved in the control of the termination step of translation (Frolova et al., 1994). Further evidence that Dom34 is participating in translation is provided by the analysis of polyribosome profiles. Dom34-deficient cells exhibit significant decrease in the levels of polyribosomes and a concomitant increase in the amount 
of free $40 \mathrm{~S}$ and $60 \mathrm{~S}$ ribosomal subunits and $80 \mathrm{~S}$ monosomes relative to those in wild type cells (Davis and Engebrecht, 1998). Wu et al. (2014) have shown that PELO is a host factor in Drosophila that is required for high efficiency translation of viral caspids and targeting Pelo could be a strategy for general inhibition of viral infection.

\subsection{Spermatogenesis in mouse}

Spermatogenesis is a well-organized and complex process, which can generate 100 million spermatozoa each day (de Rooij, 1998). Primordial germ cells (PGCs) are the first germ cells, which originate in the proximal epiblast. BMP signaling induces the migration of PGCs at embryonic day (E)7.5 towards the fetal gonad. The PGCs develop in the gonad to gonocytes between E8.5-12.5 in mouse (Philliphs et al., 2010). Gonocytes are mitotically active till E16.5 and enter G0 mitotic arrest (Fig. 1.2). During the first week of postnatal development, gonocytes resume proliferation and migrate towards the basement membrane of the seminiferous tubule. The transformation of gonocytes to spermatogonia at the basement membrane occurs between postnatal days P3 - P6 (Bellve et al., 1977). The dynamics of gonocyte proliferation, death and differentiation is fundamental for establishment of spermatogonia and consequently for spermatogenesis (Zogbi et al., 2012).

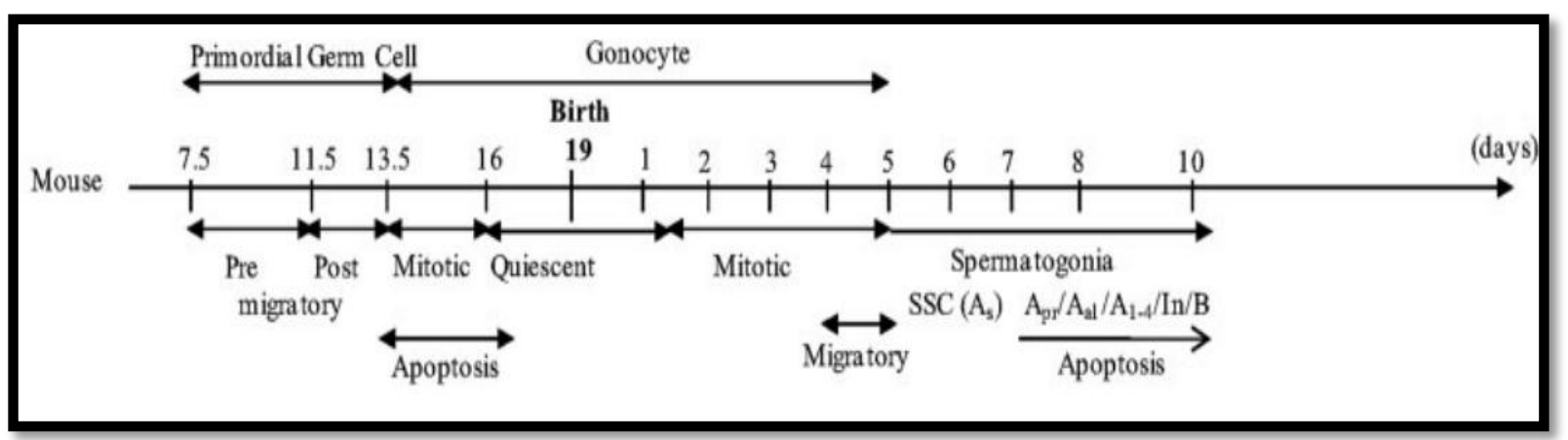

Fig. 1.2. Schematic illustration of the germ cell development. PGCs start migrating via the hindgut towards the fetal gonad at E7.5 and become gonocytes. The gonocytes are mitotically active until E16.5 and enter a quiescence phase. During the first week of postnatal development, gonocytes migrate towards the periphery of the tubules and mature to SSCs (Adopted from Culty, 2009).

Spermatogenesis arises from the SSCs throughout the life except for the first wave of spermatogenesis, which is given rise by gonocytes, the precursor of SSCs (Yoshida et al., 2006). The SSCs are located at the basement membrane of the seminiferous tubules. They exist as $A$ single $\left(A_{s}\right)$ cells, which divide to produce $A$ paired $\left(A_{p r}\right)$ spermatogonia. $A_{p r}$ 
spermatogonia either produce two new $\mathrm{A}_{\mathrm{s}}$ spermatogonia or remain attached by an intercellular cytoplasmic bridge and produce a chain of four $A$ aligned $\left(\mathrm{A}_{\mathrm{al}}\right)$ spermatogonia at next division (Fig. 1.3). Although no specific marker is established for every stage of spermatogonia, GFRa1, $\alpha-6$ integrin, PLZF, Oct3/4, Sall4, Thy1, $\beta$-integrin are used as marker for undifferentiated spermatogonia including $\mathrm{A}_{\mathrm{s}}, \mathrm{A}_{\mathrm{pr}}$ and $\mathrm{A}_{\mathrm{al}}$ spermatogonia (Buaas $e t$ al., 2004; Tokuda et al., 2007; Schlesser et al., 2008). Neurogenin 3 (Ngn3) is highly expressed in undifferentiated spermatogonia, which undergo differentiation $\left(\mathrm{A}_{\mathrm{al}}\right)$ (Yoshida et al., 2004). The differentiated spermatogonia proliferate to generate A1, A2, A3, A4, intermediate (In) and B differentiating spermatogonia. The B spermatogonia further differentiate into meiotic spermatocytes, haploid spermatids and spermatozoa. In the seminiferous tubules, all types of spermatogonia are localized at the peripheral basement membrane and the subsequent differentiating cell types are arranged in a sequential order towards the lumen (Suzuki et al., 2009).

While the regulation of PGCs migration and transition to gonocytes is under the control of BMP signaling, the maturation and maintenance of SSCs are under the regulation of phosphatidylinositol 3-kinase (PI3K)/Akt signaling pathway (Goertz et al., 2011). The glial cell-derived growth factor (GDNF) secreted by Sertoli cells, activates the Ret/GFR Rl tyrosine kinase receptor complex, which in turn activates the PI3K/Akt signaling pathway. The GDNF-mediated PI3K/Akt pathway is known to regulate the function of transcriptional activity of FOXO1 and plays an essential role in SSC self-renewal as its deficiency leads to progressive germ cell loss phenotype (Braydich-Stolle et al., 2007; Goertz et al., 2011). Phosphorylation of FOXO proteins by Akt leads to its cytoplasmic translocation and inactivation (Brunet et al., 1999; Kops et al., 1999). Therefore, the balanced activation of FOXO proteins via PI3K/Akt critically regulates SSC self-renewal and differentiation. Analyses of conditional Foxol knockout mice revealed that FOXO1 is not only critical for SSC self-renewal, but also during many of the spermatogenic stages. 


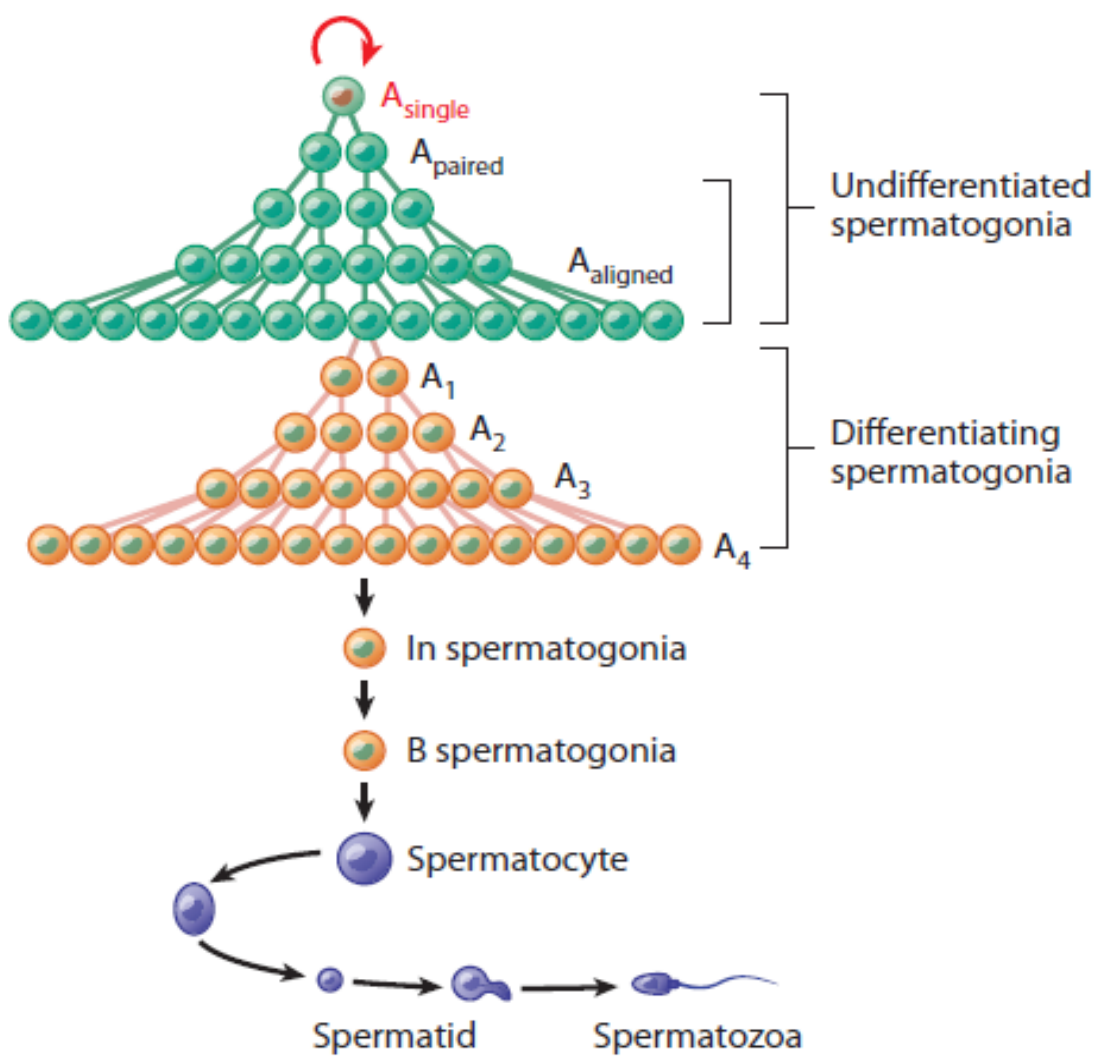

Fig. 1.3 Spermatogenesis in mouse. Spermatogenesis arises from spermatogonial stem cells (SSC). The $A_{s}$ spermatogonia have the self-renewal property and also give rise to $A_{p r}$ spermatogonia which undergo mitotic division and give rise to spermatogonia. $\mathrm{A}_{\text {al }}$ spermatogonia range from 4-32. Upon further differentiation the $A_{a l}$ spermatogonia yield type $A_{1-4}$ which after many mitotic division form spermatocytes. Spermatocytes complete the meiotic division to yield mature spermatozoa (Adopted from Kanatsu-Shinohara and Shinohara, 2013).

\subsection{Aim of this study}

The aim and experimental approaches devised for this study can be summarized as follows:

1. The primary aim of this study was to investigate the consequence of Pelo deletion on male fertility in mouse and to identify the germ cell stage in adult life that is affected by Pelo deletion. For that we deleted Pelo in adult mouse and analyzed germ cell development at various time points of Pelo deletion.

2. In order to know if the Pelo deletion affects the embryonic germ cells (gonocytes), Pelo was deleted at E12.5 and investigated the effect of Pelo deletion on gonocytes and Sertoli cells at E18.5 by immunohistochemical analysis. 
3. To investigate whether the maturation of Pelo-deficient SSCs occurred normally in postnatal stage, the development of germ cells was determined at first and second postnatal week by immunohistochemistry and protein analyses.

4. To determine the role of PELO in regulation of PI3K/Akt signaling, protein and immunohistological analyses were performed.

5. To further elucidate the possible function of PELO, we identified putative interacting partners of PELO by Yeast two-hybrid screening of ESC library using Pelo cDNA as bait.

6. To determine the consequence of Pelo depletion on the activity of BMP signaling, we have established and analyzed a BMP responsive reporter cell line $\left(\mathrm{Pelo}^{\mathrm{F} / \mathrm{BRE}-}\right.$ FFLuc). 


\section{MATERIALS AND METHODS}

\subsection{Materials}

\subsubsection{Animals}

Pelo $^{\mathrm{F} / \mathrm{F}}$ Cre ERT mice used in this study were generated in the Institute of Human Genetics, University of Göttingen (Nyamsuren et al., 2014). All experiments involving mice were performed according to protocols authorized by the Institutional Animal Care and Use Committee of the University of Göttingen.

\subsubsection{Primers used in this study}

$\begin{array}{ll}\text { Pelo } \mathrm{F} & \text { 5'-CGGACAATAAAGTGCTCCTGG-3' } \\ \text { Pelo } \mathrm{R} & \text { 5'-GCTGCCTTTGTG TCTGAAAGG-3' } \\ \text { Egr4 F } & \text { 5'-GACGCGCTTCTCTCCAAG-3' } \\ \text { Egr4 R } & \text { 5'-CTCAAAGCCCAGCTCAAGAA-3' } \\ \text { Ret } \mathrm{F} & \text { 5'-GGCTGAAGCTGATTTTGCTC-3' } \\ \text { Ret } \mathrm{R} & \text { 5'-CATAGAGCAGAGGTGTGCCA-3' } \\ \text { Lhx } 1 \mathrm{~F} & \text { 5'-AATGTAAATGCAACCTGACCG-3' } \\ \text { Lhx } 1 \mathrm{R} & \text { 5'-AACCAGATCGCTTGGAGAGA-3' } \\ \text { Sall4 F } & \text { 5'-AGCACATCAACTGGGAGGAG-3' } \\ \text { Sall4 R } & \text { 5'-GACTAAAGAACTCGGCACAGC -3' } \\ \text { Hprt } \mathrm{F} & \text { 5'-AGCCCCAAAATGGTTAAGGTTGC-3' } \\ \text { Hprt } \mathrm{R} & \text { 5'- TTGCAGATTCAACTTGCGCTCAT-3' } \\ \text { Sdha F } & \text { 5'-GCTTGCGAGCTGCATTTGG-3' } \\ \text { Sdha } \mathrm{R} & \text { 5'-CATCTCCAGTTGTCCTCTTCCA-3' }\end{array}$




\subsubsection{Sterilizations of solutions and equipments}

All solutions that were not heat sensitive were sterilised at $121^{\circ} \mathrm{C}, 10^{5} \mathrm{~Pa}$ for $60 \mathrm{~min}$ in an autoclave (Webeco, Bad Schwartau). Heat sensitive solutions were filtered through a disposable sterile filter ( 0.2 to $0.45 \mu \mathrm{rn}$ pore size). Plastic wares were autoclaved as above. Glass wares were sterilised overnight in an oven at $220^{\circ} \mathrm{C}$.

\subsection{Methods}

\subsubsection{Isolation of nucleic acids}

\subsubsection{Isolation of genomic DNA}

Mouse tail tip was incubated in $100 \mu$ lof lysis buffer I containing $5 \mu$ l proteinase $\mathrm{K}(20 \mu \mathrm{g} / \mu \mathrm{l})$ at $55^{\circ} \mathrm{C}$ overnight in Thermomixer. The enzymatic activity was inactivated at $85^{\circ} \mathrm{C}$ for one hour. The tissue lysate was then centrifuged at $14000 \mathrm{x}$ g for $15 \mathrm{~min}$ and the supernatant was transferred into a new Eppendorf tube. DNA was precipitated by adding an equal volume of isopropanol, mixed by inverting several times and centrifuged at $14000 \mathrm{x} \mathrm{g}$ at room temperature (RT) for 15 min. DNA was washed with $1 \mathrm{ml}$ of $70 \%$ ethanol, dissolved in 50$100 \mu \mathrm{lof} \mathrm{dH}_{2} \mathrm{O}$ and incubated at $55^{\circ} \mathrm{C}$ for $5 \mathrm{~min}$.

\subsubsection{Isolation of plasmid DNA}

A single bacterial colony was inoculated in $5 \mathrm{ml} \mathrm{LB}$ medium, containing an appropriate antibiotic, and incubated at $37^{\circ} \mathrm{C}$ for $12-16$ hours with a shaking speed of 160 rotations per minute $(\mathrm{rpm})$. The medium was centrifuged at $4000 \mathrm{x} \mathrm{g}$ for $10 \mathrm{~min}$. The pellet obtained was resuspended in $100 \mu \mathrm{l}$ of resuspension solution $\mathrm{P} 1$ (50 mM Tris/HCl, $\mathrm{pH}$ 8.0; $10 \mathrm{mM}$ EDTA; $100 \mu \mathrm{g} / \mathrm{ml}$ RNase A, Invitrogen). The bacterial cells were lysed with $200 \mu 1$ of lysis solution P2 (200 mM NaOH; 1\% SDS, Invitrogen), incubated at RT for 5 min and then neutralised with $150 \mu \mathrm{l}$ of neutralisation solution $\mathrm{P} 3$ (3M Potassium acetate, $\mathrm{pH} 5.5$, Invitrogen). The precipitated solution was incubated at RT for $5 \mathrm{~min}$ and centrifuged at $13000 \mathrm{x} \mathrm{g}$ at RT. The supernatant was transferred into a new tube, where $1 \mathrm{ml}$ of $100 \%$ ethanol was added to precipitate the DNA. Then it was incubated for $3 \mathrm{~min}$ at RT, centrifuged at full speed for 20 min, and finally the pellet was washed with $350 \mu$ of $70 \%$ ethanol and after air-drying dissolved in $30 \mu$ lof $\mathrm{dH}_{2} \mathrm{O}$. 


\subsubsection{Isolation of DNA fragments after agarose gel electrophoresis}

This method is designed to extract and purify DNA of $70 \mathrm{bp}$ to 10 kilobase pairs $(\mathrm{kb})$ in length from agarose gels. Up to $400 \mu \mathrm{g}$ agarose can be processed per spin column. The principle of this method depends on selective binding of DNA to uniquely designed silica-gel membrane. To the excised DNA fragment from agarose, 3 volumes of QG buffer was added and incubated at $50^{\circ} \mathrm{C}$ for $10 \mathrm{~min}$. After the gel slice was dissolved completely, it was applied over a QiAquick column and centrifuged for $1 \mathrm{~min}$. The flow through was discarded and the column was washed with $0.75 \mathrm{ml}$ of PE buffer. After drying the column, it was placed into a fresh microcentrifuge tube. To elute DNA, $50 \mu$ lof EB buffer was applied to the centre of the QIAquick membrane and centrifuged for $1 \mathrm{~min}$.

\subsubsection{Plasmid DNA transformation into competent bacteria}

Transformation of competent bacteria (DH5 $\alpha$ or C600) was done by gently mixing with $10 \mu 1$ of ligation reaction, after thawing them on ice for $30 \mathrm{~min}$. Following incubation for $20 \mathrm{~min}$ on ice, bacteria were heat-shocked for $45 \mathrm{sec}$ at $38^{\circ} \mathrm{C}$ and cooled down for $2 \mathrm{~min}$ on ice. After adding $500 \mu 1$ of LB medium, the mixture was incubated at $37^{\circ} \mathrm{C}, 400 \mathrm{rpm}$, for 1 hour to allow recovery of heat shocked bacteria which then were plated on LB-agar plates.

\subsubsection{Restriction digestion of DNA}

Restriction enzyme digestions were performed by incubating double-stranded DNA with an appropriate amount of restriction enzyme in its respective buffer as recommended by the supplier, and at the optimal temperature for the specific enzyme. Standard digestions include 2-10 U enzyme per microgram of DNA. These reactions were usually incubated for 1-3 hrs to ensure complete digestion at the optimal temperature for enzyme activity, which was typically $37^{\circ} \mathrm{C}$. For genomic DNA digestion, the reaction solution was incubated overnight at $37^{\circ} \mathrm{C}$.

\subsubsection{Ligation of DNA fragments}

The ligation of an insert DNA into a vector (digested with appropriate restriction enzyme) was carried out in the following reaction mix:

30 ng vector DNA (digested) 
50-100 ng insert DNA (1:3, vector: insert ratio)

$1 \mu$ ligation buffer (10x)

$1 \mu 1 \mathrm{~T} 4 \mathrm{DN}$ A ligase $(5 \mathrm{U} / \mu \mathrm{l})$

in a total volume of $10 \mu 1$

Blunt-end ligations were carried out at $16^{\circ} \mathrm{C}$ for overnight, whereas overhang-end ligations were carried out at room temperature for 2-4 hrs.

\subsubsection{TA-Cloning}

Taq polymerase and other DNA polymerases have a terminal transferase activity that results in the non-template addition of a single nucleotide to the 3'-ends of PCR products. In the presence of all 4 dNTPs, the dATP is preferentially added. This terminal transferase activity is the basis of the TA-cloning strategy. For cloning of PCR products, pGEM-T Easy vector system that has 5'-T overhangs was used. The followings were mixed:

50 ng of pGEM-T Easy Vector

PCR product (1:3, vector to insert ratio)

$1 \mu$ of T4 DN A Ligase 10X buffer

$1 \mu \mathrm{l}$ of T4 DNA Ligase in a total volume of $10 \mu \mathrm{l}$

The content was mixed by pipetting and the reaction was incubated overnight at $16^{\circ} \mathrm{C}$.

\subsubsection{Isolation of total RNA, cDNA synthesis, RT-PCR and quantitative real time PCR}

Total RNA was extracted using the TRIzol reagent following the manufacturer's instructions (Life Technology). About $100 \mathrm{mg}$ of tissue were homogenized in $1 \mathrm{ml}$ of Trizol Reagent using a glass teflon homogenizer. The homogenate was vortexed and incubated on ice for 5 min to permit the complete dissociation of nucleoprotein complexes. Then $0.2 \mathrm{ml}$ of cold chloroform was added, mixed vigorously, kept on ice for $10 \mathrm{~min}$. After centrifugation at $13000 \mathrm{xg}$ for $15 \mathrm{~min}$ at $4^{\circ} \mathrm{C}$, the upper aqueous phase was transferred into a new Eppendorf 
cup. By adding $0.5 \mathrm{ml}$ isopropanol, RNA was precipitated and subsequently washed with $75 \%$ ethanol. Finally, the RNA pellet was dissolved in $\sim 50 \mu 1$ of $\mathrm{DEPCdH}_{2} \mathrm{O}$ and stored at $-80^{\circ} \mathrm{C}$. For cDNA synthesis, five micrograms of total RNA was used in the SuperScript II System (Life Technology). To avoid the genomic DNA contamination, total RNAs were treated with RNA-free DNaseI (Sigma Aldrich) for $15 \mathrm{~min}$ at $37^{\circ} \mathrm{C}$. For checking cDNA synthesis quality by RT-PCR with housekeeping gene HPRT, $0.5 \mu 1$ of 1:20 diluted cDNA was used. Quantitative RT-PCR was performed using the QuantiFast SYBR Green PCR Master Mix following manufacturer's instructions (QIAGEN). The reactions were performed in triplicate and run in an ABI 7900HT Real-Time PCR System (Applied Biosystems).

\subsubsection{Protein extraction and Western blotting}

Total cellular proteins were extracted by homogenizing testes in RIPA lysis buffer (Millipore, Germany) supplemented with a proteinase inhibitor cocktail (Roche Diagnostics, Germany) and phosphatase inhibitor (SERVA, Heidelberg, Germany) and incubated on ice for $1 \mathrm{~h}$. Homogenates were sonicated and then centrifuged at $13000 \times g$ for $20 \mathrm{~min}$ at $4^{\circ} \mathrm{C}$. The concentration of proteins was estimated using a Bio-Rad protein assay kit (Bio-Rad Laboratories, Munich, Germany). To determine the activity of the PI3K/Akt signaling pathway, testes were isolated from control and mutant P7 or adult mice and de-capsulated, and seminiferous tubules (STs) were incubated at $37^{\circ} \mathrm{C}$ in StemPro ${ }^{\circledR}-34 \mathrm{SFM}{ }^{\circledR}$ Medium (Life Technologies) supplemented with $1 \%$ fetal calf serum in the presence or absence of $100 \mathrm{ng} / \mathrm{ml}$ GDNF (Life Technologies) and/or $30 \mu \mathrm{M}$ LY2940002 inhibitor (Sigma Aldrich, Germany). After $1 \mathrm{~h}$ of treatment, STs were collected by centrifugation, washed, and subjected to protein extraction. Protein samples were separated by 4-12\% SDS-PAGE and transferred onto nitrocellulose membranes (Amersham Biosciences, Braunschweig, Germany). Membranes were then blocked for $1 \mathrm{~h}$ with 5\% non-fat milk in PBST. Blots were probed at $4{ }^{\circ} \mathrm{C}$ overnight with antibodies against pAkt, Akt, FOXO1, PARP (Cell Signaling Technologies) at 1:2000, NGN3 (Proteintech Group) at 1:2000 or PELO (Burnicka-Turek et al., 2010) at 1:10000 dilution. The blots were re-probed with anti- $\alpha$-tubulin antibody (\#T5168, Sigma-Aldrich) at 1:20000 dilution as a loading control. Following thorough washings, blots were incubated with the corresponding secondary antibodies. Signals were detected using Amersham ECL Prime Western Blotting Detection Reagent (GE Healthcare). Signals were captured and quantified using AlphaView software, version 3.2.0 (Cell Biosciences, Inc.). 


\subsubsection{Preparation of nuclear and cytoplasmic protein fractions}

Nuclear and cytoplasmic protein extracts were prepared using NE-PER Nuclear and Cytoplasmic Extraction Reagents (Thermo Scientific) according to the manufacturer's instruction. Testes were collected, washed and homogenized in ice-cold CER I buffer. After incubation on ice for $10 \mathrm{~min}$, ice-cold CER II was added to the testis suspension, mixed, and incubated for $1 \mathrm{~min}$ on ice. The cytoplasmic fractions were collected after centrifugation at $16.000 \times g$ for $5 \mathrm{~min}$, and the nuclear pellets were re-suspended in ice-cold NER, and incubated for $40 \mathrm{~min}$ with vortexing for $15 \mathrm{~s}$ every $10 \mathrm{~min}$. The nuclear extracts were collected after centrifugation $\left(16.000 \times g\right.$ for $10 \mathrm{~min}$ at $\left.4{ }^{\circ} \mathrm{C}\right)$. The prepared nuclear fractions were then processed for western blotting as described above.

\subsubsection{Histological and immunocytochemical analysis}

\subsubsection{Tissue collection and preparation for paraffin embedding}

Testis samples were immediately fixed in Bouin's solution after collection for $24 \mathrm{hrs}$ to prevent alteration in the cellular structure. The tissue was dehydrated gradually by incubating in a series of increasing alcohol concentrations such as $70 \%, 80 \%, 90 \%$ and $100 \%$ ethanol for two hours in room temperature. The tissue was left in $100 \%$ ethanol for overnight which then was incubated in $100 \%$ xylol for three hours. Later, $100 \%$ xylol was replaced with new mixture of xylol and paraffin at 1:1 ratio and incubated in $65^{\circ} \mathrm{C}$ incubator overnight. Before embedding into paraffin blocks the tissue were incubated in pure paraffin which was changed every hour for at least 8 hours. Finally the paraffin blocks were prepared by placing the tissue in pure melted paraffin in embedding mould. The block was allowed to cool and was then sectioned in the microtome into $5 \mu \mathrm{m}$ sections or stored at $4{ }^{\circ} \mathrm{C}$.

\subsubsection{Haemotoxylin and Eosin staining of mouse testis}

Tissue sections were incubated in xylol twice for five minutes and once for ten minutes to remove the paraffin from the section. The rehydration was achieved by incubating them in a decreasing ethanol series $(100 \%, 90 \%, 80 \%$ and $70 \%)$ for 2 min each. The sections were then immersed in Mayer's Haemotoxylin solution for 1-2 min and washed in sterile water or under running tap water for $5 \mathrm{~min}$. The slides were then placed in acid ethanol $(250 \mu \mathrm{HCl}$ in $100 \mathrm{ml}$ $70 \%$ ethanol) to remove the excess Haemotoxylin. Later, they were transferred to ammonia 
water $(300 \mu \mathrm{l}$ ammonia in $100 \mathrm{ml}$ water) before incubating in Eosin solution for 3-4 min until the desired the color intensity was achieved. The slides were then washed in water several times and subjected to a series of increasing concentration of ethanol for 1 min each. Finally, they were incubated in $100 \%$ xylol for $10 \mathrm{~min}$ and let to dry before mounted with a cover slip using Eukitt mounting media. The sections were then viewed under a phase contrast microscope (BX, 60; Olympus).

\subsubsection{Immunostaining of mouse tissue}

Tissue sections were removed of paraffin and the rehydration was performed as described above. After washing in PBS containing 0.1\% Tween-20 (PBST) for five minutes, the slides were boiled in antigen retrieval buffer $(10 \mathrm{mM}$ sodium citrate) for $6 \mathrm{~min}$ and cooled on ice for 15 min. They were then washed in PBST for five min and the immunostaining was performed using R.T.U. Vectastain Universal Quick Kit according to the manufacturer's instructions (Vector Laboratories, Burlingame, USA). Briefly, after washing with PBS containing 0.1\% Tween 20 (PBST), sections were blocked and incubated overnight with anti-SALL4 (\#ab29112, Abcam, Cambridge, UK), anti-FOXO1 (\#2880, Cell Signaling Technology, Leiden, The Netherlands), anti-HSPA4 (\#sc-6240, Santa Cruz Biotechnology, Heidelberg, Germany), or anti-GCNA1 antibodies at 1:100 dilutions. After washing with PBST, sections were incubated with secondary antibody for $10 \mathrm{~min}$ at RT, followed by incubation with streptavidin conjugated to horseradish peroxidase for $5 \mathrm{~min}$. Sections were then incubated in peroxidase substrate solution until the desired stain intensity developed and counterstained with hematoxylin, rinsed, mounted with Roti ${ }^{\circledR}$ Mount Aqua (Carl Roth, Germany) and imaged using an Olympus BX60 microscope (Olympus, Karlsruhe, Germany).

\subsubsection{Yeast two-hybrid screening}

To identify the interaction partners of PELO, mouse ECS cDNA library (Zheng et al., 2012) was screened using pGBKT7-Pelo (Burnika-Turek et al., 2010) in a Yeast two-hybrid screening method. After excluding the auto-activation by co-transformation of pGBKT7-Pelo with empty pGADT7 vector into AH109 yeast strain, the bait construct was transformed into Y187 yeast strain. The Y2H screen was performed on ESC cDNA library using Matchmaker pre-transformed library protocol (Clontech). Briefly, the pre-transformed ESC library in yeast strain AH109 was mixed and mated together with strain Y187 containing the pGBKT7-Pelo. After $24 \mathrm{~h}$ of mating, the culture was spread on SD/-Leu/-Trp/-His/-Ade plates and the 
surviving colonies were verified on SD/-Leu/-Trp/-His/-Ade/+ X- $\alpha$-Gal plates. The positive clones that were blue on $\mathrm{X}-\alpha-\mathrm{Gal}$ were inoculated for overnight culture and the plasmid DNA was isolated using QIAprep Spin Miniprep Kit. By PCR amplification and sequencing using vector specific primers, we obtained the sequences of cDNA inserts. Identities of prey cDNA clones were determined by BLAST analysis. To test the auto-activation or interaction, the prey cDNA clones were co-transformed with either empty pGBKT7 vector or pGBKT7-Pelo into AH109 strain, respectively. The co-transformants were first selected on SD/-Leu/-Trp plates and later tested for the reporter gene expression on SD/-Leu/-Trp/-His/-Ade and X- $\alpha$ Gal plates. The surviving clones without auto-activation were identified as putative interaction partners of Pelo and characterized further.

\subsubsection{Computer and statistical analyses}

For the analysis of nucleotide sequences, programs like BLAST, BLAST2 and other programs from National Centre for Biotechnology Information (NCBI) were used (www. ncbi.nlm.nih.gov/15.09.2014). For restriction analysis of DNA, NEB cutter V2.0 or Webcutter program were used (http://tools.neb.com/NEBcutter2/index.php; http://rna.lundberg.gu. se/cutter2/08.08.2014). For primer design, Primer 3 software was used (http://Frodo.wi.mit.edu/10.09.2014). ExPASy tools were used for proteins and their domains information (www.Expasy.org/10.12.2014). Mouse genome sequence and other information about mouse genes were referred from Ensembl (www.ensembl.org/index.html/04.06.2014). Paired comparisons of the number of marker-positive cells/tubule in control and mutant testes were performed using Student's $t$-tests. A $p$-value less than 0.05 were considered statistically significant. All statistical analyses were performed using the Statistica 9 software package (StatSoft Inc., Tulsa, OK, USA). Data are shown as mean \pm standard deviation (S.D.). 


\section{RESULTS}

The crucial role of Pelo in early embryonic development was evident from the analysis of Pelo conventional knockout mouse model. To investigate the biological function of Pelo in germ cell development we analyzed Pelo conditional knockout mouse model. We studied the role of Pelo by induced deletion at different developmental stages and analyzed the defects resulting from Pelo deletion. The following result sections contain a brief description of the aim and results of the study in context of the complete thesis, the status of each manuscript as well as authors contributions.

3.1 Pelota mediates gonocyte maturation and maintenance of spermatogonial stem cells in mouse testes

3.2 Pelota regulates the development of extraembryonic endoderm through activation of bone morphogenetic protein (BMP) signaling 


\subsection{Pelota mediates gonocyte maturation and maintenance of spermatogonial stem cells in mouse testes}

In this part of the study, we conditionally deleted Pelo to determine its function in male germ cell development at various stages: embryonic, post natal and adult. Deletion of Pelo in adult mouse led to exhaustion of the SSCs, while spermatogenic cells that are post meiotic are not affected and are capable of developing fertilization efficient spermatozoa. Further, the deletion of Pelo during embryonic development revealed that the PELO is dispensable for maintenance of gonocytes. But, Pelo deletion impaired the maturation of gonocytes to SSCs during the post natal development. Immunohistological and protein analyses indicated that the activity of PI3K/Akt pathway was highly activated in the absence of PELO. In mutant testes, we found that enhanced activity of PI3K/Akt pathway decreases the transcriptional activity of FOXO1, which induces the expression of genes that maintain the balance between SSC selfrenewal and differentiation. Taken together, our results indicate that PELO attenuates PI3K/Akt signaling and that the enhanced activity of PI3K/Akt and subsequent FOXO1 transcriptional inactivation are responsible for the impaired development of SSCs in Pelo mutant testes.

Authors: Priyadharsini Raju*, Gunsmaa Nyamsuren*, Manar Elkenani, Aleksandra Kata, Erdenechimeg Tsagaan, Wolfgang Engel, Ibrahim M. Adham

* contributed equally to this work

Status: Published in Reproduction, 2015, 149(3): 213-221

\section{Impact factor: 3.262}

\section{Author contributions to the work:}

1. Priyadharsini Raju: Determined the consequence of Pelo deletion at various developmental stages, gonocyte maturation and SSC development during early postnatal stage, molecular studies to inquire the affected signaling pathway, sample and data collection, participated in data analysis and interpretation, involved in manuscript preparation.

2. Gunsmaa Nyamsuren: Determined the consequence of Pelo deletion on development of germ cells in adult mice, involved in manuscript preparation.

3. Manar Elkenani: Involved in the verification of the affected signaling pathway. 
4. Aleksandra Kata: Participated in generation of Pelo conditional knockout mouse, primary experiments to determine the male fertility of Pelo-deficient mice.

5. Tsagaan Chimgee: Participated in sample collection and histological analyses.

6. Wolfgang Engel: Conception and design of experiments and interpretation of the data.

7. Ibrahim M. Adham: Conception and design of experiments, interpretation of the data, data analysis, helped to draft the manuscript. 


\title{
Pelota mediates gonocyte maturation and maintenance of spermatogonial stem cells in mouse testes
}

\author{
Priyadharsini Raju*, Gunsmaa Nyamsuren*, Manar Elkenani, Aleksandra Kata, \\ Erdenechimeg Tsagaan, Wolfgang Engel and Ibrahim M Adham \\ Institute of Human Genetics, University Medical Center of Göttingen, Heinrich-Düker-Weg 12, \\ 37073 Göttingen, Germany \\ Correspondence should be addressed to I M Adham; Email: iadham@gwdg.de \\ *(P Raju and G Nyamsuren contributed equally to this work)
}

\begin{abstract}
Pelota $(P e / o)$ is an evolutionarily conserved gene, and its deficiency in Drosophila affects both male and female fertility. In mice, genetic ablation of Pelo leads to embryonic lethality at the early implantation stage as a result of the impaired development of extra-embryonic endoderm (ExEn). To define the consequences of Pelo deletion on male germ cells, we temporally induced deletion of the gene at both embryonic and postnatal stages. Deletion of Pelo in adult mice resulted in a complete loss of whole-germ cell lineages after 45 days of deletion. The absence of newly emerging spermatogenic cycles in mutants confirmed that spermatogonial stem cells (SSCs) were unable to maintain spermatogenesis in the absence of PELO protein. However, germ cells beyond the undifferentiated SSC stage were capable of completing spermatogenesis and producing spermatozoa, even in the absence of PELO. Following the deletion of Pelo during embryonic development, we found that although PELO is dispensable for maintaining gonocytes, it is necessary for the transition of gonocytes to SSCs. Immunohistological and protein analyses revealed the attenuation of FOXO1 transcriptional activity, which induces the expression of many SSC self-renewal genes. The decreased transcriptional activity of FOXO1 in mutant testes was due to enhanced activity of the PI3K/AKT signaling pathway, which led to phosphorylation and cytoplasmic sequestration of FOXO1. These results suggest that PELO negatively regulates the PI3K/AKT pathway and that the enhanced activity of PI3K/AKT and subsequent FOXO1 inhibition are responsible for the impaired development of SSCs in mutant testes.
\end{abstract}

Reproduction (2015) 149 213-221

\section{Introduction}

After sexual differentiation, primordial germ cells (PGCs) in male fetal gonads become gonocytes that proliferate until embryonic day 15.5 (E15.5) and remain mitotically quiescent until shortly after birth (Culty 2009). The gonocytes are the precursors of spermatogonial stem cells (SSCs) and give rise to the first wave of spermatogenesis, whereas subsequent waves are derived from SSCs (Kluin \& de Rooij 1981, Yoshida et al. 2006). Maintenance of male germ cell production throughout the life time of an individual is the result of tightly controlled balance between SSC self-renewal and differentiation (Oatley et al. 2006). Self-renewal of SSCs requires complex crosstalk between extrinsic signals from Sertoli cells and cellular intrinsic regulators of SSCs. One of the key growth factors secreted by Sertoli cells is glial cell line-derived neurotrophic factor (GDNF), which exerts its biological effects by binding to its receptor components GFR $\alpha 1$ and $\mathrm{c}$-Ret and activating the PI3K/AKT signaling pathway in SSCs
(Meng et al. 2000, Sariola \& Saarma 2003, Naughton et al. 2006). The PI3K/AKT signaling pathway regulates the activity of many transcription factors, and, in turn, their targeted proteins control SSC self-renewal (Lee et al. 2007). The transcriptional activity of the FOXO family of fork-head transcription factors is negatively regulated via the PI3K/AKT signaling pathway. Phosphorylation of FOXO proteins by AKT leads to its cytoplasmic translocation and inactivation (Brunet et al. 1999, Kops et al. 1999). Therefore, the balanced activation of FOXO proteins via PI3K/AKT critically regulates SSC self-renewal and differentiation. Analyses of conditional FOXO1-knockout mice revealed that FOXO1 is not only critical for SSC self-renewal, but also for the transition of gonocytes to SSCs. During this transition, which occurs in the first week of postnatal development, the AKT-dependent phosphorylation of FOXO1 prevents its nuclear translocation, resulting in the inhibition of its transcriptional activity (Goertz et al. 2011). 
Pelota $(P e / o)$ is an evolutionarily conserved gene that has been identified in diverse species from archaebacteria to humans (Ragan et al. 1996, Shamsadin et al. 2000, 2002). The PELO protein contains an RNA-binding domain similar to that found in eukaryotic release factor I (eRF1), which is involved in the terminal step of protein synthesis (Davis \& Engelbrecht 1998). The biological role of PELO was originally identified in Drosophila melanogaster, in which Pelo-null mutants exhibited spermatogenic arrest at the G2/M boundary of the first meiotic division (Eberhart \& Wasserman 1995). Subsequently, the impaired fertility of mutant females was not found to be a defect during meiotic division but rather the result of a disrupted balance between the self-renewal and differentiation of germline stem cells (GSCs). This study revealed a critical role for Pelo in controlling GSC self-renewal, which is mediated by repressing the differentiation pathway in GSCs (Xi et al. 2005).

The function of PELO at the molecular level has been extensively investigated in yeast, in which the PELO ortholog Dom 34 and its interacting partner $\mathrm{Hsb}$ w were found to participate in an RNA quality control mechanism called No-Go decay (NGD). NGD recognizes $m R N A$ s on which the ribosome is stalled at a stable stem-loop, rare codon, or pseudoknot, triggering the endonucleolytic cleavage of these mRNAs (Doma \& Parker 2006, Graille et al. 2008, Chen et al. 2010). Further experiments revealed that Dom34 recycles stalled ribosomes from mRNAs lacking stop codons, truncated mRNAs, or the noncoding regions of many cellular mRNAs (Shoemaker \& Green 2011, Tsuboi et al. 2012, Shao et al. 2013, Guydosh \& Green 2014). Failure to recycle stalled ribosomes would ultimately lead to a critical default of the translational machinery (Guydosh \& Green 2014). Despite the significant role of Dom34 in RNA quality control and translational machinery, it is dispensable for yeast survival (Carr-Schmid et al. 2002). In contrast, depletion of Peloleads to embryonic lethality at an early post-implantation stage in mice (Adham et al. 2003). To determine the role of PELO during embryonic and postnatal life, we generated a conditional knockout mouse model (Nyamsuren et al. 2014). Characterization of Pelo-null embryonic stem cells (ESCs) revealed that a PELO deficiency did not markedly affect the selfrenewal of ESCs, but impaired their differentiation into extra-embryonic endoderm (ExEn). Furthermore, PELO depletion led to failure in the reprograming of somatic cells toward induced pluripotent stem cells due to inactive BMP signaling and an impaired mesenchymalto-epithelial transition (Nyamsuren et al. 2014).

To date, the consequences of PELO deficiency on the development of male germ cells in mice have not been investigated. In this study, we found that PELO is required for SSC self-renewal and maintenance, but is dispensable for the development of later stages of spermatogenesis and sperm function. In addition, we showed that the transition of gonocytes to SSCs is impaired in the absence of PELO. At the molecular level, we showed that the exhaustion of SSCs and impaired conversion of gonocytes to SSCs are the result of elevated PI3K/AKT activity and decreased transcriptional activity of FOXO1 that induces the expression of genes that maintain the balance between SSC self-renewal and differentiation.

\section{Materials and methods}

\section{Mouse strains, treatments, and sample collection}

The generation of conditional Pelo-knockout (Pelo ${ }^{\mathrm{F} / F} \mathrm{CreERT2}$ ) mice was described previously (Nyamsuren et al. 2014). To conditionally delete Pelo in Pelo ${ }^{F / F}$ CreERT2 mice, 8-week-old male mice were injected intraperitoneally (i.p.) with $1 \mathrm{mg}$ tamoxifen (Tam) for 5 consecutive days. To investigate the progression of spermatogenesis after Tam application, males were killed at different time points after Tam-treatment. Immediately following this step, testes were weighed; one testis was fixed in Bouin's solution for histological analyses, and the other was frozen for molecular studies. To inactivate Pelo at neonatal stages, pregnant Pelo ${ }^{F / F}$ CreERT2 mice were treated i.p. with Tam at E17.5 as before. After birth, the offspring were genotyped, and testes were collected at postnatal days 1 (P1), P7, and P14. Testes from Tam-treated $\mathrm{Pelo}^{F / F}$ mice were prepared at the same time points as controls to assess any unspecific effects of Tam. To detect Cre-mediated Pelo recombination, which deletes floxed exons 2 and 3, a piece of frozen testis was genotyped by PCR as described previously (Nyamsuren et al. 2014). All animal procedures were approved by the Institutional Animal Care and Use Committee of the University of Göttingen.

\section{Fertility test}

To investigate the fertility of Tam-treated $P e l o^{F / F} C r e E R T 2$ and $\mathrm{PelO}^{\mathrm{F} / \mathrm{F}}$ males, the animals were each intercrossed with three WT CD1 females after 15, 45, and 60 days of Tam treatment. Females were checked daily for the presence of vaginal plugs (VP), and VP-positive females were placed in separate cages to give birth. Offspring of each male were genotyped to determine the CreERT2-mediated deletion of the floxed Pelo alleles and the fertility of mutant males.

\section{Tissue processing and immunohistochemistry}

Bouin's fixed testes were embedded in paraffin and cut into $5-\mu \mathrm{m}$ sections for immunohistochemistry. The sections were deparaffinized in xylene, rehydrated through a graded ethanol series, and either stained with hematoxylin and eosin (H\&E) or subjected to immunohistochemistry. For immunohistochemistry, sections were boiled in $10 \mathrm{mM}$ sodium citrate antigen retrieval buffer for $6 \mathrm{~min}$ and cooled on ice for $10 \mathrm{~min}$. To eliminate endogenous peroxidase activity, sections were immersed in 3\% hydrogen peroxide in methanol for $15 \mathrm{~min}$ at room temperature (RT). The following procedures were performed using the R.T.U. Vectastain Universal Quick Kit (Vector Laboratories, Burlingame, CA, USA) according to the 
manufacturer's instructions. Briefly, after washing with PBS containing $0.1 \%$ Tween 20 (PBST), sections were blocked and incubated overnight with anti-SALL4 (\#ab29112, Abcam, Cambridge, UK), anti-FOXO1 ( $\# 2880$, Cell Signaling Technology, Leiden, The Netherlands), anti-HSPA4 (\#sc-6240, Santa Cruz Biotechnology), or anti-GCNA1 antibodies at 1:100 dilutions. After washing with PBST, sections were incubated with secondary antibody for $10 \mathrm{~min}$ at RT, followed by incubation with streptavidin conjugated to HRP for $5 \mathrm{~min}$. The sections were then incubated in peroxidase substrate solution until the development of desired stain intensity and counterstained with hematoxylin, rinsed, mounted with Rot Mount Aqua (Carl Roth, Karlsruhe, Germany) and imaged using an Olympus BX60 microscope (Olympus, Karlsruhe, Germany).

\section{Western blotting}

Total cellular proteins were extracted by homogenizing testes in RIPA lysis buffer (Millipore, Schwalbach, Germany) supplemented with a proteinase inhibitor cocktail (Roche Diagnostics) and phosphatase inhibitor (SERVA, Heidelberg, Germany) and incubated on ice for $1 \mathrm{~h}$. The homogenates were sonicated and then centrifuged at $13000 \mathrm{~g}$ for $20 \mathrm{~min}$ at $4{ }^{\circ} \mathrm{C}$. The concentration of proteins was estimated using a Bio-Rad protein assay kit (Bio-Rad Laboratories). To determine the activity of the PI3K/AKT signaling pathway, testes were isolated from control and mutant P7 or adult mice and de-capsulated, and seminiferous tubules (STs) were incubated at $37^{\circ} \mathrm{C}$ in StemPro-34SFM Medium (Life Technologies) supplemented with $1 \%$ FCS in the presence or absence of $100 \mathrm{ng} / \mathrm{ml} \mathrm{GDNF}$ (Life Technologies) and/or $30 \mu \mathrm{M}$ LY2940002 inhibitor (SigmaAldrich). After $1 \mathrm{~h}$ of treatment, STs were collected by centrifugation, washed, and subjected to protein extraction. The protein samples were separated by $4-12 \%$ SDS-PAGE and transferred onto nitrocellulose membranes (Amersham Biosciences). The membranes were then blocked for $1 \mathrm{~h}$ with $5 \%$ nonfat milk in PBST. The blots were probed at $4{ }^{\circ} \mathrm{C}$ overnight with antibodies against pAKT, AKT, FOXO1, PARP (Cell Signaling Technologies) at 1:2000, NGN3 (Proteintech Group, Manchester, UK) at 1:2000, or PELO (Burnicka-Turek etal. 2010) at 1:10 000 dilution. The blots were re-probed with anti- $\boldsymbol{\alpha}$-tubulin antibody (\#T5168, Sigma-Aldrich) at 1:20 000 dilution as a loading control. Following thorough washings, blots were incubated with the corresponding secondary antibodies. The signals were detected using the Amersham ECL Prime Western Blotting Detection Reagent (GE Healthcare, Buckinghamshire, UK). The signals were captured and quantified using AlphaView software, version 3.2.0 (Cell Biosciences, Inc., Santa Clara, CA, USA).

\section{Preparation of nuclear protein fractions}

Nuclear and cytoplasmic protein extracts were prepared using the NE-PER Nuclear and Cytoplasmic Extraction Reagents (Thermo Scientific) according to the manufacturer's instruction. Briefly, testes were collected, washed, and homogenized in ice-cold CER I buffer. After incubation on ice for $10 \mathrm{~min}$, ice-cold CER II was added to the testis suspension, mixed, and incubated for $1 \mathrm{~min}$ on ice. The cytoplasmic fractions were collected after centrifugation at $16000 \mathrm{~g}$ for $5 \mathrm{~min}$, and the nuclear pellets were re-suspended in ice-cold NER, and incubated for $40 \mathrm{~min}$ with vortexing for $15 \mathrm{~s}$ every $10 \mathrm{~min}$. The nuclear extracts were collected after centrifugation $(16000 \mathrm{~g}$ for $10 \mathrm{~min}$ at $4{ }^{\circ} \mathrm{C}$ ). The prepared nuclear fractions were then processed for western blotting as described previously.

\section{Quantitative real-time PCR}

Total RNA was extracted using the TRIzol reagent following the manufacturer's instructions (Life Technologies, Darmstadt, Germany). Five micrograms of total RNA were used for cDNA synthesis using the SuperScript II System (Life Technology). To avoid the genomic DNA contamination, total RNAs were treated with RNA-free DNasel (Sigma-Aldrich) for $15 \mathrm{~min}$ at $37^{\circ} \mathrm{C}$. Quantitative real-time PCR (qRT-PCR) was performed using the QuantiFast SYBR Green PCR Master Mix following the manufacturer's instructions (Qiagen). The reactions were performed in triplicate and run in an ABI 7900HT Real-Time PCR System (Applied Biosystems). Hypoxanthine-guaninephosphoribosyl transferase (Hprt) or succinate dehydrogenase (Sdha) expression levels were used for normalization and for analysis of relative changes in gene expression. The primers sequence for PCR and qRT-PCR are as follows: Pelo, $5^{\prime}$-CGGA CAATAAAGTGCTCCTGG- $3^{\prime}$ (forward) and 5'-GCTGCCT TTGTG TCTGAAAGG-3' (reverse); Egr4, 5'-GACGCGCTTCTC TCCAAG- $3^{\prime}$ (forward) and $5^{\prime}$-CTCAAAGCCCAGCTCAAGAA$3^{\prime}$ (reverse); Ret, 5'-GGCTGAAGCTGATTTTGCTC-3' (forward) and $5^{\prime}$-CATAGAGCAGAGGTGTGCCA-3' (reverse); L $h \times 1$, $5^{\prime}$-AATGTAAATGC AACCTGACCG- $3^{\prime}$ (forward) and $5^{\prime}$-AACCAGATCGCTTGGAGAGA-3' (reverse); Sall4, 5' ${ }^{\prime}$-AGCACATCAACTGGGAGGAG- $3^{\prime}$ (forward) and 5'-GACTAAAGAACTCGGCACAGC-3' (reverse); Hprt, 5'-AGCCCCAAAATGGTTAAGGTTGC-3' (forward) and $5^{\prime}$-TTGCAGATTCAACTTGCGCTCAT-3' (reverse); Sdha, 5'-GCTTGCGAGCTGCATTTGG-3' (forward) and $5^{\prime}$-CATCTCCAGTTGTCCTCTTCCA-3' (reverse).

\section{Statistical analyses}

Paired comparisons of the number of marker-positive cells per tubule in control and mutant testes were performed using Student's $t$-tests. A $P$ value $<0.05$ was considered to be statistically significant. All statistical analyses were performed using the Statistica 9 software package (StatSoft, Inc., Tulsa, OK, USA). Data are shown as mean \pm s.D.

\section{Results}

\section{Deletion of Pelo disrupts fertility in adult male mice}

We studied the consequence of Pelo deficiency on male fertility by the temporal deletion of the gene in Pelo ${ }^{\mathrm{F} / \mathrm{F}}$ CreERT2 mice, which have floxed Pelo alleles and a knock-in allele containing Tam-induced Cre recombinase driven by the ubiquitously expressed Rosa26 promoter (Nyamsuren et al. 2014). Excision of floxed exons 2 and 3 of Pelo was induced by i.p. administration of Tam for 5 consecutive days. Time points from the last Tam injection were expressed as days 
post-injection (DPI). Control animals were Tam-treated $\mathrm{PelO}^{\mathrm{F} / \mathrm{F}}$ mice lacking the CreERT2 allele, which are phenotypically equivalent to animals with the WT allele. To assay the CreERT2-mediated deletion of the floxed Pelo allele in the testes of Tam-treated Pelo ${ }^{\mathrm{F} / \mathrm{F}} \mathrm{CreERT2}$ males (thereafter referred to as Pelo mutant or Pelo ${ }^{\Delta / 4}$ ), PCR genotyping, western blotting, and qRT-PCR analyses were performed on testicular DNA, RNA, and proteins, respectively, isolated from mice at $5 \mathrm{DPI}$. The Cre-mediated deletion of the floxed allele generated a null allele as verified by PCR (Fig. 1A). Protein and qRTPCR analyses revealed that the expression of PELO was diminished to $<85 \%$ in testes of mutants compared with that of control Pelo ${ }^{F / F}$ mice (Fig. $1 \mathrm{C}$ and D).

Upon Pelo deletion, mutant mice at 45 DPI showed a significant decrease in testicular size when compared with control mice (Fig. 1E and F). We then defined the progression of male infertility by breeding mutant and control mice with WT females after 15, 45, and $60 \mathrm{DPI}$. After $15 \mathrm{DPI}$, mutant males were fertile and produced litter of normal size $(14.3 \pm 2.1$ pups, $n=5$ vs control $13.8 \pm 2.1$ pups, $n=5$ ). PCR analysis revealed that the mutant allele $\left(\right.$ Pelo $\left.^{\Delta}\right)$ is transmitted to $\sim 93 \%$ of offspring (Fig. 1B), suggesting that Pelo deletion did not disrupt the progression of meiotic and post-meiotic cells to functional sperm. In contrast, all mutant males were infertile after 45 and 60 DPI.

\section{Pelo is required for SSCs maintenance but is dispensable for later spermatogenic stages}

To determine the cause of male infertility, histological analyses and expression patterns of different germ cell markers were studied in testicular sections derived from mutant and control animals at 5, 15, 25, and $45 \mathrm{DPI}$. Verification of H\&E-stained tubular sections at $5 \mathrm{DPI}$ showed no marked differences in the diameters of STs or in the presence of different types of germ cells between control and mutant testes (Fig. 2A, B, C, and D). However, by 15 and $25 \mathrm{DPI}$, most STs were devoid of pre-meiotic cells and retained only post-meiotic germ cells that were closely located at the peripheral layers of the STs (Fig. 2E, F, G, and H). By 45 DPI, $87 \%$ of STs were devoid of most germ cells in the mutant testes (Fig. 2I and J). The absence of new waves of meiotic germ cells in $\sim 88 \%$ of mutant STs after 15 days of Pelo deletion indicates that the early stages of undifferentiated spermatogonia are affected by PELO deficiency.

To confirm the disruption of early stages of spermatogonia, we estimated the numbers of GCNA1- and SALL4-positive germ cells in the cross-sections of control and mutant testes. GCNA1 is expressed in undifferentiated spermatogonia to the preleptotene spermatocyte stage, whereas the expression of SALL4 in testes is restricted to undifferentiated spermatogonia $\left(A_{s}\right.$ to $\left.A_{a l}\right)$, a subset of which is considered to be SSCs (Hobbs et al. 2012). No significant differences were detected in the number of GCNA1-positive cells per tubule in mutant testes compared with that in control by $5 \mathrm{DPI}$, but this number sharply dropped in mutant testes by $15 \mathrm{DPI}$ (Fig. 3A and B). The numbers of SALL4-positive spermatogonia were not significantly different between mutant and controls at $5 \mathrm{DPI}$ and were slightly increased at $15 \mathrm{DPI}$, but were absent in $90 \%$ of mutant STs by 25 DPI (Fig. 3A and C). In mice, progression of spermatogonia to sperm takes about 35 days, whereas the
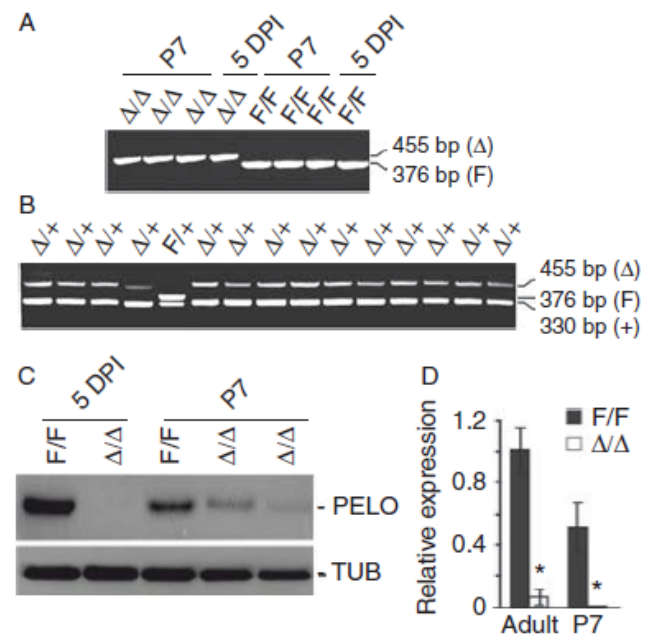

E

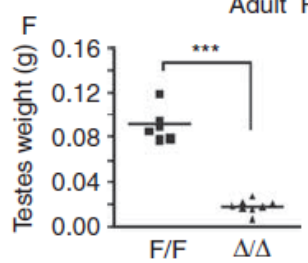

Figure 1 Conditional deletion of Pelo affects male fertility. (A) Genotyping PCR analysis using primers specifically amplifying the genomic fragments of WT $(+)$, floxed $(F)$, and recombined $(\Delta)$ alleles of Pelowas performed on genomic DNA isolated from the testes of control Pelo ${ }^{F / F}$ and mutant Pelo ${ }^{\Delta / \Delta} \mathrm{P} 7$ or adult mice at $5 \mathrm{DPI}$. The presence of an amplified 455-bp fragment of Pelo 4 allele and the loss of a 376-bp of Pelo ${ }^{F}$ allele in mutant testes demonstrated successful Cre-mediated recombination. (B) Genotyping PCR was performed on genomic DNA isolated from tail of pups obtained from the breeding of mutant males at 15 DPI with WT females. Transmission of the Pelo ${ }^{\Delta}$ allele to offspring indicated that Pelo deletion did not affect the progression of spermatogenic cells to spermatozoa with fertilizing capability. (C) Western blotting of testicular proteins extracted from adult Pelo ${ }^{\mathrm{F} / \mathrm{F}}$ and Pelo ${ }^{\Delta / \Delta}$ mice at $5 \mathrm{DPI}$ or from P7 mutant mice using anti-PELO antibodies. The blot was stripped and reprobed for $\alpha$-tubul in (TUB). (D) Expression levels of Pelo in the testes of adult Pelo ${ }^{F / F}$ and Pelo ${ }^{\Delta / \Delta}$ mice after $5 \mathrm{DPI}$, or from P7 Pelo $o^{F / F}$ and $\mathrm{Pelo}^{\Delta / \Delta}$ mice, were determined by qRT-PCR. Values of expression levels normalized to Hprt and are presented as mean \pm s.D. of three animals. Transcript levels of control adult mice were expressed as 1.0. *Significantly different from controls; $P<0.05$. (E) Representative image of the relative size of testes from adult Pelo ${ }^{F / F}$ and Pelo ${ }^{4 / \Delta}$ mice at 45 DPI. (F) Comparison of testis weights from adult control and mutant mice at $45 \mathrm{DPI}$. Results are shown as mean \pm s.D. of six animals from each genotype. *** Significantly different from controls; $P<0.05$. 

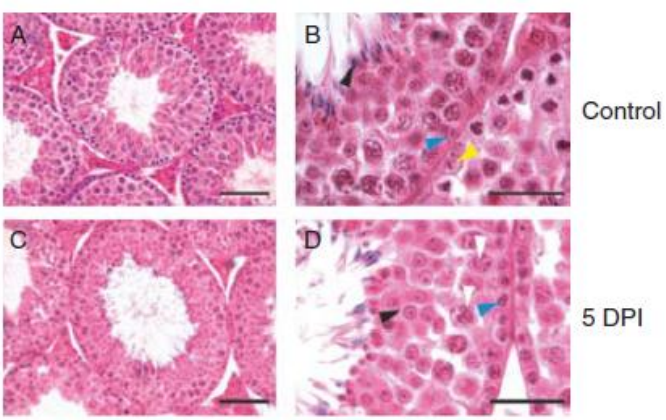

$5 \mathrm{DPI}$
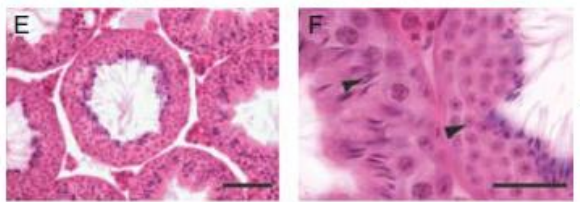

15 DPI
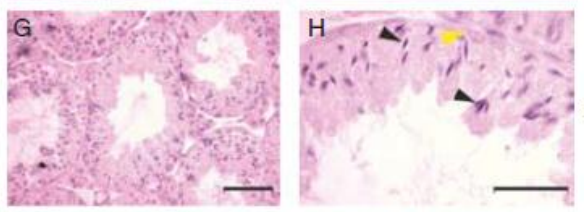

25 DPI
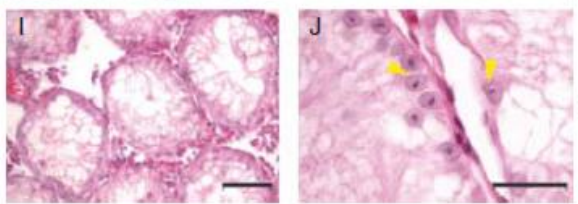

45 DPI

Figure 2 PELO deficiency leads to spermatogenic failure. Testes sections from adult control ( $A$ and $B$ ) and mutant mice at 5 (C and $D$ ), 15 ( $E$ and $\mathrm{F}), 25$ ( $\mathrm{G}$ and $\mathrm{H}$ ), and $35 \mathrm{DPI}(\mathrm{I}$ and $\mathrm{J})$ were stained with $\mathrm{H} \& \mathrm{E}$. Compared with control testes (A and $\mathrm{B}$ ), all pre-meiotic (blue arrowheads), meiotic (white arrowheads), and post-meiotic (black arrowheads) germ cells were recognized in STs of mutant mice at 5 DPI (C and D). Most STs of mutant mice at 15 (E and F) and 25 DPI (G and $\mathrm{H})$ were devoid of pre-meiotic cells and contained round and elongated spermatids located at the periphery. Very few STs at 15 DPI contained meiotic cells. In most STs of mutant testes at 45 DPI, only Sertoli cells (yellow arrowheads) could be recognized at basement membrane, and vacuoles were present in the region lacking germ cells (I and J). Scale $\operatorname{bar}(A, C, E, G$, and $\mathrm{I})=20 \mu \mathrm{m} ;(\mathrm{B}, \mathrm{D}, \mathrm{F}$, and $\mathrm{J})=10 \mu \mathrm{m}$.

seminiferous epithelial cycle for the development of SSCs $\left(A_{s}\right)$ into differentiated $B$ spermatogonia normally requires about 2 weeks. The absence of a new wave of differentiated spermatogonia in $83 \%$ of STs in mutant testes by $15 \mathrm{DPI}$ as well as the retention of comparable numbers of SALL4-positive cells in both genotypes up to $15 \mathrm{DPI}$ suggests that PELO deficiency only affects the early developmental stages of spermatogonia but does not disrupt the subsequent stages of germ cell development. Moreover, reduced number of $\mathrm{GCNA}^{+}{ }^{+}$cells in spite of the presence of SALL4 ${ }^{+}$cells at 15 DPI suggests that the Pelo-deficient SALL4 ${ }^{+}$cells could not further differentiate and continue spermatogenesis. To assess the impaired differentiation of spermatogonia, we analyzed the expression of NGN3, which is expressed in undifferentiated spermatogonia that are destined for differentiation (Nakagawa et al. 2010). As shown in Fig. 3D, the expression levels of NGN3 were significantly reduced in Pelo-null testes after 2 and 5 DPI, suggesting that arrested spermatogenesis in Pelo-deficient testes is a result of failed differentiation of spermatogonia.

In order to investigate whether these undifferentiated spermatogonia undergo apoptosis, in the absence of differentiation, we checked the expression levels of cleaved PARP, a specific marker of apoptosis, in testes after different time point of Pelo deletion. As shown in Fig. 3E, no significant differences in expression levels of cleaved PARP in mutant testes after different time point

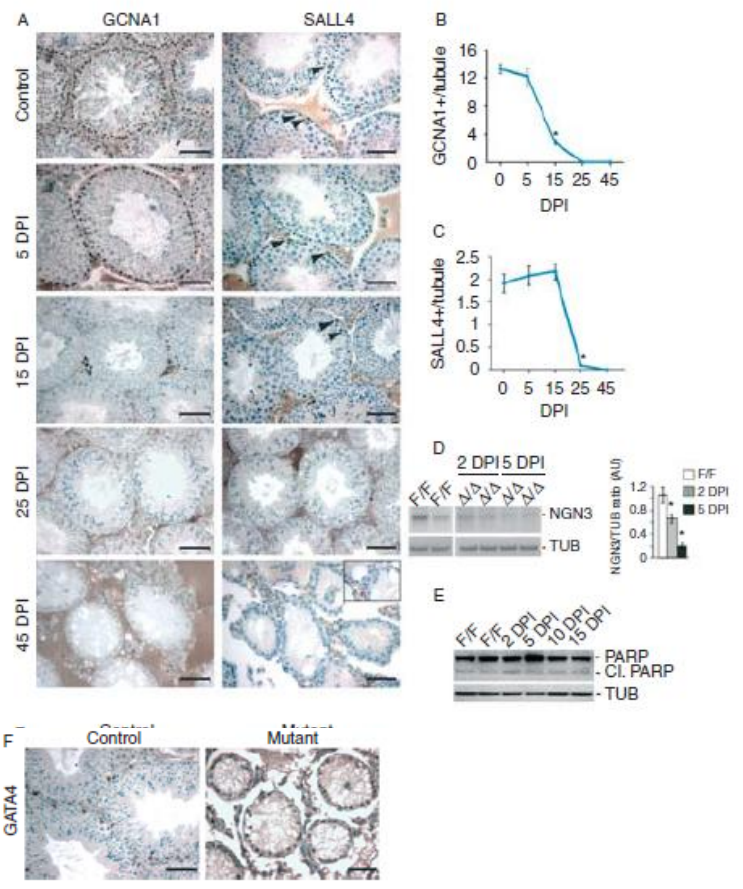

Figure 3 PELO is required for maintenance of SSCs. Testis tissue sections from control and mutant mice at 5, 15, 25, and $45 \mathrm{DPI}$ were probed with antisera against GCNA1 (A) and Sall4 (A). Black arrowheads mark SALL4-positive cells. Counterstaining was done with hemotoxylin to stain the nucleus. (B and C) Scale bar graphs represent the mean \pm s.D. of GCNA1-positive (B) and SALL4-positive (C) cells per tubule of mutant mice after different time points of Tam treatment. *Significantly different from controls; $P<0.05 . n=3$ animals.

(D) Immunoblotting analysis for the expression of NGN3 in the testes of control (F/F) and mutant mice $(\Delta / \Delta)$ at 2 and 5 DPI (left panel). In the histogram presented in the right panel, the expression levels of NGN3 were normalized to that of $\boldsymbol{\alpha}$-tubulin (TUB). Value is presented as mean and S.D. AU, indicates arbitrary units. *Significantly different from controls; $P<0.05$. (E) Protein blotting analysis for the expression of fulllength PARP (PARP) and cleaved PARP (CI. PARP) in the testes of control (F/F) and mutant mice at 2, 5, 10, and 15 DPI. (F) Histological sections from control and mutant adult mice at 45 DPI were probed with antiGATA4 antibody. No marked changes in the number of GATA4-positive Sertoli cell nuclei in mutant testes compared with controls were observed. Scale bars (A and D) $=20 \mu \mathrm{m}$. 
of Pelo deletion were observed. These results suggest that the degeneration of arrested spermatogonia occurred not via apoptotic pathway. Furthermore, to analyze whether Pelo deletion affects Sertoli cells, we performed an immunohistological analysis of GATA4, a Sertoli cell marker. This analysis revealed the presence of comparable numbers of cells stained for GATA4 in both genotypes at $45 \mathrm{DPI}$, suggesting that Sertoli cells are unaffected by Pelo deletion (Fig. 3D).

\section{Gonocytes are unaffected by Pelo deficiency, but their transition to SSCs is disrupted}

After the homing of PGCs in the gonads of mouse embryos, PGCs proliferate and become gonocytes, which undergo G1/G0 cell cycle arrest from E15.5 until 1-2 days after birth. Between P3 and P7, gonocytes migrate toward the periphery of the STs; when they reach the basement membrane, they develop into SSCs (Culty 2009). To determine the effect of Pelo deletion on the development of germ cells, pregnant females were injected i.p. with Tam at E17.5. Later, the testes of the pups were isolated at P1, P7, and P14 and subjected to further analyses. Genotyping PCR showed the successful recombination of the floxed allele in mutant pups (Fig. 1A). RNA and protein analyses revealed that the expression levels of Pelo in mutant testes were reduced by more than $75 \%$ compared with controls (Fig. 1C and D).

Effects of PELO deficiency on gonocytes were elucidated by the expression analyses of gonocyte marker HSPA4, which is highly enriched in gonocytes and subsequently downregulated in SSCs (Held et al. 2011). The numbers of HSPA4-positive gonocytes in Pelo-deficient testes at P1 were not significantly different from those of controls, indicating that PELO deficiency does not disrupt gonocytes (Fig. 4A and B). The immunohistochemical analysis of mutant testes at P7 and P14 showed a dramatic decrease in number of GCNA1-positive germ cells (Fig. 4C and D). These finding suggested that either the maturation of gonocytes or the development of SSCs is affected by the absence of PELO. The severe development of atopic dermatitis and high lethality of mutant mice beyond the second week of birth restricted us to follow the progression of the first and subsequent waves of spermatogenesis in later postnatal development of Pelo-deficient mice.

\section{Attenuation of transcriptional activity of FOXO1 impairs the transition of Pelo-deficient gonocytes to SSCS}

Previous studies have demonstrated that the PI3K/AKT signaling pathway regulates the development and maintenance of SSCs through the control of transcriptional activity of FOXO1. Interestingly, gonocyte maturation to SSCs is demarcated by the translocation of FOXO1 from the cytoplasm to the nucleus (Goertz etal.

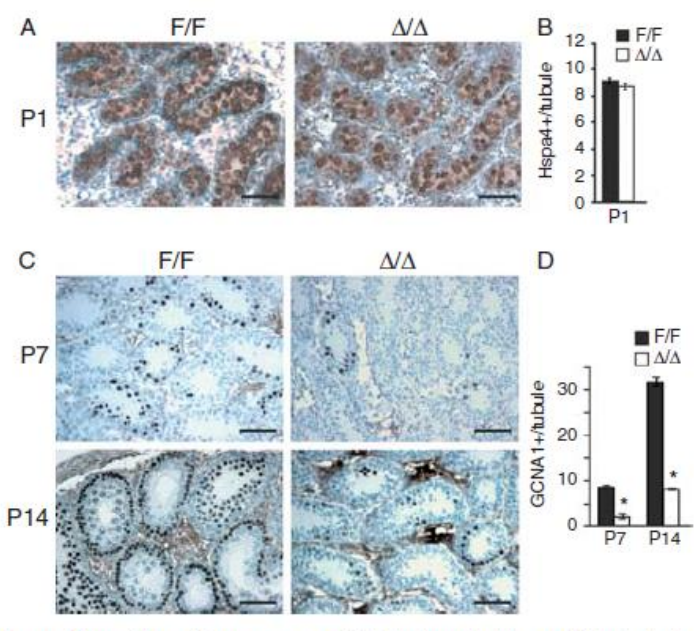

Figure 4 Transition of gonocytes to SSCs is impaired upon Pelodeletion. (A) Immunohistochemical analysis of testis tissue sections from control and mutant mice at P1 probed with gonocyte-specific marker HSPA4. Hemotoxylin is used for counterstaining. (B) The graph represents the mean number of $\mathrm{Hspa}^{+}{ }^{+}$-cells per tubule \pm S.D. in control Pelo ${ }^{\mathrm{F} F}$ and mutant Pelo $o^{\Delta / \Delta}$ mice at P1. (C) Testis tissue sections from control and mutant mice at P7 and P14 were probed with anti-GCNA1 antibody. Scale bar $(A$ and $C)=20 \mu \mathrm{m}$. The inset contains a high-magnification view of the marker-positive cells. (D) The mean of GCNA1-positive cells per tubule \pm s.D. from control and mutant mice at P7 and P14 shows a significant reduction in germ cells in Pelo-deficient testes. ${ }^{*}$ Significantly different from controls; $P<0.05$. $n=3$ per group.

2011). They showed that FOXO1 is localized in the cytoplasm of all gonocytes in testes at P1-P3 and undergoes a translocation from cytoplasm to nucleus at P3-P7. This translocation demarcates the transition of gonocytes to SSCs, where the FOXO1 is predominantly nuclear. Upon nuclear export in SSCs, the FOXO1 is degraded quickly and so often not detectable in cytoplasm. Their finding shows that gonocytes that retain nuclear localization of FOXO1 are mature while those that retain cytoplasmic FOXO1 around P7 are rather immature. To investigate whether the impaired maturation of gonocytes in Pelo-deficient testes is due to the inactivation of FOXO1, we determined the sub-cellular localization of FOXO1 in the testicular cells of mutant and control P7 and P14 mice by immunohistochemistry (Fig. 5A). At P7, a significantly increased number of germ cells with a nuclear distribution of FOXO1 were present in controls compared with mutant testes (Fig. 5A and B). By P14, most Pelo-deficient germ cells localized at the peripheral layer of STs and showed a cytoplasmic distribution of FOXO1, whereas FOXO1 localization was detected mainly in nuclei of corresponding cells in control P14 tubules (Fig. 5A and B). To confirm these results, we performed western blotting analyses using nuclear protein fractions prepared from mutant and control P7 testes. As shown in Fig. 6A, the levels of nuclear FOXO1 were significantly reduced in mutants 


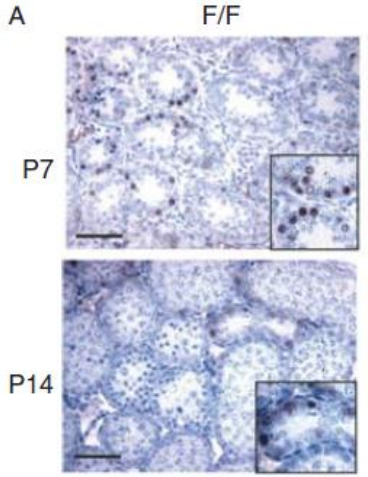

$\Delta / \Delta$

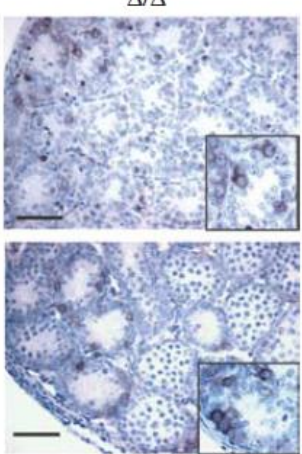

B
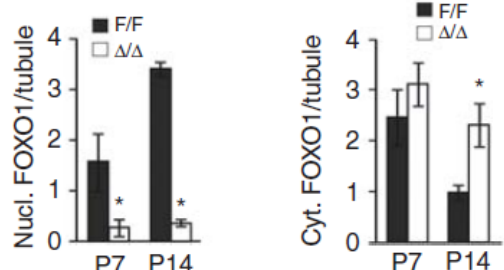

Figure 5 Sub-cellular localization of FOXO1 in control and mutant germ cells. (A) Testis sections from control and mutant mice at P7 and P14 were probed with anti-FOXO1 antibody. High magnification inserts show the localization of FOXO1. (B) Quantitative analysis of nuclear (left panel) or cytoplasmic FOXO1-positive cells per tubule (right panel) in control and mutant testes of P7 and P14 mice. Data represents mean \pm S.D. $*$ Significantly different from controls; $P<0.05$, $n=3$ per group. Scale bar $(A)=20 \mu \mathrm{m}$.

compared with controls. We then investigated the expression levels of Lhx1, Ret, Sall4, and Dppa3 by qRT-PCR, whose expression levels were significantly attenuated in the testes of Foxo1-null mice (Goertz et al. 2011). The expression levels of Sall 4 and Dppa3 were significantly lower in mutant P7 and P1 4 testes compared with controls, whereas no significant differences were detected in the expression levels of $L h x 1$ and Retbetween control and mutant testes (Fig. 6B). Collectively, these data suggest that the impaired transition of gonocytes to SSCs in mutant postnatal testes is due to the decreased transcriptional activity of FOXO1.

The proper balance of PI3K/AKT activity is critical for the development and maintenance of SSCs via FOXO1 (Singh et al. 2011); hence, we were prompted to examine whether the excessive activity of the PI3K/ AKT signaling pathway is the cause of the impaired maturation of gonocytes in mutant testes. AKT kinase is activated by phosphorylation downstream of $\mathrm{PI} 3 \mathrm{~K}$, and serves as an indirect measurement of the activity of PI3K/ AKT signaling. To define whether Pelo deficiency affects $\mathrm{PI} 3 \mathrm{~K} / \mathrm{AKT}$ activity, testes from control and mutant P7 mice were incubated for $1 \mathrm{~h}$ with or without GDNF. Western blotting analysis using anti-phospho-AKT $(\mathrm{pAKT})$ showed that the levels of basal pAKT were markedly higher in mutant testes compared with controls, and that GDNF induction further enhanced AKT activity only in mutants but not in controls (Fig. 6C). To further confirm these results, we treated STs with LY2940002, a specific inhibitor of PI3K. As shown in Fig. 6C, basal and GDNF-induced phosphorylation of AKT in mutant testes was markedly reduced after PI3K inhibition. These results suggest that the enhanced activity of the PI3K/AKT pathway in mutant testes is responsible for the impaired development of SSCs. The elevated induction of PI3K/AKT activity in STs after treatment with GDNF in the absence of Pelo confirmed these results, showing that PELO negatively regulates the PI3K/AKT pathway (Pedersen et al. 2014).

\section{Discussion}

In this report, we have investigated the biological function of PELO in male germ cell development through the temporal deletion of Pelo at different

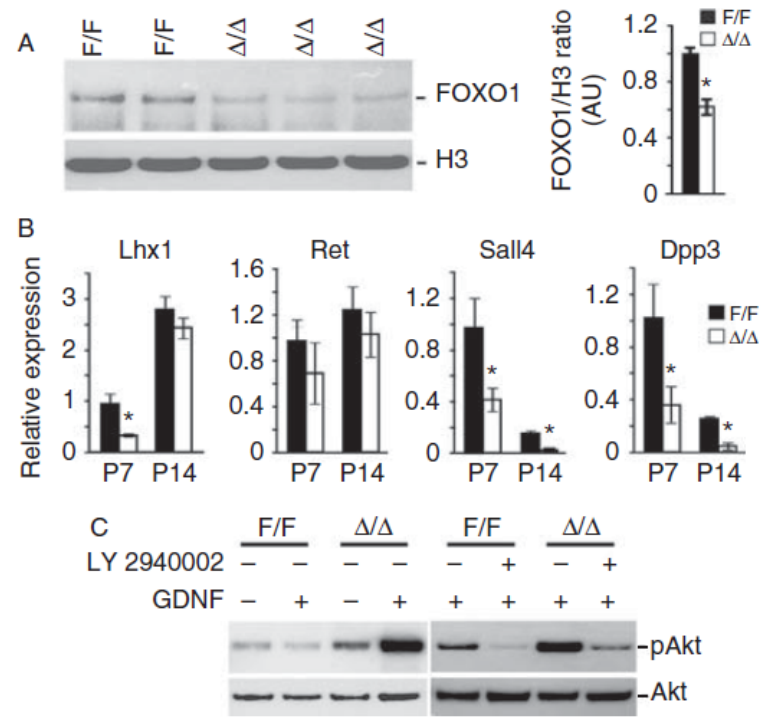

Figure 6 Enhanced activation of PI3K/AKT signaling attenuates FOXO1 transcrintional activitv in Pelo-deficient testes. (A) Western blotting with nuclear protein fractions derived from the testes of P7 control $P e l O^{F / F}$ and $P e l O^{\Delta / \Delta}$ mice were probed with anti-FOXO1 antibody. The blots were stripped and reprobed with histone $(\mathrm{H} 3)$ as a protein loading control (left panel). The histogram shows the relative intensity of nuclear FOXO1 to that of $\mathrm{H} 3$ (right panel). Protein levels of control testes are expressed as 1.0. ${ }^{*}$ Significantly different from controls; $P<0.05$. AU, indicates arbitrary units. (B) RNA isolated from testes of P7 and P14 control and mutant mice was used to determine the expression levels of $L h x 1$, Ret, Sall4, and Dppa3 by qRT-PCR. Values of expression levels normalized to Hprt or Sdha are presented as mean \pm s.D. Transcript levels in control testes were expressed as 1.0. *Significantly different from controls; $P<0.05 . n=3$ per age and genotype. (C) STs from P7 control and mutant testes were incubated with or without $100 \mathrm{ng} / \mathrm{ml}$ GDNF and/or PI3K inhibitor LY2940002 $(30 \mu \mathrm{M})$ for $60 \mathrm{~min}$. The blots of protein extracts were probed with PAKT antibody and subsequently with anti-AKT antibody that recognized total AKT protein as a protein loading control. 
developmental stages. PELO deficiency in adult mice results in the depletion of all germ cells after 45 days of gene deletion. The absence of new emerging spermatogenic cycles in the mutants confirmed that the SSCs were unable to maintain spermatogenesis in the absence of PELO. However, germ cells that entered the spermatogenic cycle are capable of completing spermatogenesis and producing spermatozoa. The gradual loss of SALL4-positive undifferentiated and GCNA1-positive spermatogonia in the Pelo mutants suggests the exhaustion of the SSC pool and the loss of undifferentiated spermatogonia. Moreover, the absence of a new wave of spermatogenesis showed that self-renewal of SSCs is impaired in the absence of PELO. The dramatic disruption of spermatogenesis in Pelo-deficient mice is similar to that observed in mice lacking the Plzf, Etv5, Foxo1, or Shp2 genes, which regulate the self-renewal of SSCs (Costoya et al. 2004, Simon et al. 2007, Goertz et al. 2011, Puri et al. 2014).

Despite the fact that PELO is essential for the maintenance of SSCs, their precursors were not sensitive to PELO depletion. However, gonocyte derivates were differentially affected by PELO depletion. Although a subset of gonocytes differentiated and gave rise to the first wave of spermatogenesis, as indicated by the presence of meiotic cells in 2-week-old mutant testes, the maturation of mutant gonocytes to SSCs was impaired. These results indicate that PELO is not required for gonocyte survival or differentiation of their derivates during the first wave of spermatogenesis. Previous studies demonstrated that the transcription factor FOXO1 plays an essential role in the developmental conversion of gonocytes to SSCs via the induction of many genes, whose encoded proteins are required for the development and maintenance of SSCs (Goertz et al. 2011, Ngo et al. 2013). Our investigation of the sub-cellular localization of FOXO1 showed a clear impairment in the transition of gonocytes to SSCs, as most of the gonocytes retained FOXO1 in the cytoplasm and were unable to transform to SSCs. Thus, there were a reduced number of GCNA1-positive spermatogonia in the absence of PELO during postnatal development. Further the absence of spermatogenesis confirms the impairment of these cells to maintain spermatogenesis in the absence of PELO. The phosphorylation of FOXO1 is mediated by the activation of the PI3KJAKT signaling pathway. The GDNF-mediated $\mathrm{PI} 3 \mathrm{~K} / \mathrm{AKT}$ pathway is known to play an essential role in SSC self-renewal as its deficiency leads to progressive germ cell loss phenotype (Braydich-Stolle et al. 2007). Our results showed that both basal and GDNF-induced AKT phosphorylation is enhanced in Pelo-deficient testes, suggesting that PELO negatively regulates GDNFmediated PI3K/AKT activation. The AKT-dependent phosphorylation of FOXO1 triggers its rapid nuclear export and subsequent degradation via the ubiquitinproteosome degradation pathway (Huang \& Tindall 2011). A recent study has shown that PELO antagonists direct the binding of the $\mathrm{p} 84$ regulatory subunit of $\mathrm{PI} 3 \mathrm{~K}$ to active HER2 and the epidermal growth factor receptor in tumor cell lines (Pedersen et al. 2014). Therefore, it is likely that PELO regulates $\mathrm{PI} 3 \mathrm{~K} / \mathrm{AKT}$ and its mediator FOXO1 in the regulation of SSC development and maintenance. This hypothesis is supported by our results, which show higher levels of PAKT, the downstream mediator of PI3K, in mutants compared with WTs. The higher levels of pAKT in Pelo mutant testes in turn phosphorylate FOXO1, resulting in its cytoplasmic localization and inactivation. The reduction in the levels of pAKT upon the addition of PI3K inhibitor further confirmed that the PI3K/AKT signaling cascade was enhanced in the absence of PELO. Consistent with our findings, SSC depletion was also accompanied by a persistent increase in PI3K/AKT activity in mice lacking PTEN, which normally antagonizes the PI3K/AKT pathway (Goertz et al. 2011). On the other hand, the nuclear retention of FOXO1 in the absence of GILZ resulted in the accumulation of SSCs, as their differentiation potential was impaired (Ngo et al. 2013).

In conclusion, we have shown the evidence that PELO indirectly regulates the sub-cellular localization of FOXO1, as PI3K/AKT signaling is highly activated in the absence of PELO. This in turn affects SSC pool formation, disrupts the balance between SSC selfrenewal and differentiation, and contributes to a loss of spermatogenesis. Thus, PELO is essential for finely regulating the signals required for the maintenance of spermatogenesis.

\section{Declaration of interest}

The authors declare that there is no conflict of interest that could be perceived as prejudicing the impartiality of the research reported.

\section{Funding}

This work was supported in part by University Medical Center of Goettingen. P Raju is supported by Indian Council of Agricultural Research (ICAR) International fellowship. M Elkenani is supported by fellowship from Egyptian Government.

\section{Acknowledgements}

The authors are grateful to Dr D V K Pantakani for critically reading the manuscript. They thank G C Enders (Kansas University, Medical Center, Kansas City, USA) for providing the GCNA1 antibody.

\section{References}

Adham IM, Sallam MA, Steding G, Korabiowska M, Brinck U, Hoyer-FenderS, Oh C \& Engel W2003 Disruption of the Pelota gene causes early embryonic lethality and defects in cell cycle progression. Molecular and Cellular Biology 23 1470-1476. (doi:10.1128/MCB.23.4.1470-1476.2003) 
Braydich-Stolle L, Kostereva N, Dym M \& Hofmann MC 2007 Role of Src family kinases and $\mathrm{N}-\mathrm{Myc}$ in spermatogonial stem cell proliferation. Developmental Biology 304 34-45. (doi:10.1016/j.ydbio.2006.12.013)

Brunet A, Bonni A, Zigmond MJ, Lin MZ, Juo P, Hu LS, Anderson MJ, Arden KC, Blenis J \& Greenberg ME 1999 Akt promotes cell survival by phosphorylating and inhibiting a Forkhead transcription factor. Cell 96 857-868. (doi:10.1016/S0092-8674(00)80595-4)

Burnicka-Turek O, Kata A, Buyandelger B, Ebermann L, Kramann N, Burfeind P, Hoyer-Fender S, Engel W \& Adham IM 2010 Pelota interacts with HAX1, EIF3G and SRPX and the resulting protein complexes are associated with the actin cytoskeleton. BMC Cell Biology 1128 . (doi:10. 1186/1471-2121-11-28)

Carr-Schmid A, Pfund C, Craig EA \& Kinzy TG 2002 Novel G-protein complex whose requirement is linked to the translational status of the cell. Molecular and Cellular Biology 22 2564-2574. (doi:10.1128/MCB. 22.8.2564-2574.2002)

Chen L, Muhlrad D, Hauryliuk V, Cheng Z, Lim MK, Shyp V, Parker R \& Song H 2010 Structure of the Dom34-Hbs1 complex and implications for no-go decay. Nature Structural \& Molecular Biology 17 1233-1240. (doi:10.1038/nsmb.1922)

Costoya JA, Hobbs RM, Barna M, Cattoretti G, Manova K, Sukhwani M, Orwig KE, Wolgemuth DJ \& Pandolfi PP 2004 Essentials role of Plzf in maintenance of spermatogonial stem cells. Nature Genetics 36 653-659. (doi:10.1038/ng1367)

Culty M 2009 Gonocytes, the forgotten cells of the germ cell lineage. Birth Defects Research. Part C, Embryo Today: Reviews 87 1-26. (doi:10.1002/ bdrc.20142)

Davis L \& Engelbrecht J 1998 Yeast dom 34 mutants are defective in multiple developmental pathways and exhibit decreased levels of polyribosomes. Genetics 149 45-56.

Doma MK \& Parker R 2006 Endonucleolytic cleavage of eukaryotic mRNAs with stalls in translation elongation. Nature 440 561-564. (doi:10.1038/ nature04530)

Eberhart CG \& Wasserman SA 1995 The Pelota locus encodes a protein required for meiotic cell division: an analysis of G2/M arrest in Drosophila spermatogenesis. Development 121 3477-3486.

Goertz MJ, Wu Z, Gallardo TD, Hamra F \& Castrillon DH 2011 Foxo1 is required in mouse spermatogonial stem cells for their maintenance and the initiation of spermatogenesis. Joumal of Clinical Investigation 121 3456-3466. (doi:10.1172/JCl57984)

Graille M, Chaillet M \& van Tilbeurgh H 2008 Structure of yeast Dom34, a protein related to translation temination factor Erf1 and involved in No-Go decay. Journal of Biological Chemistry 283 7145-7154. (doi:10.1074/jbc.M708224200)

Guydosh NR \& Green R 2014 Dom34 rescues ribosomes in 3' untranslated regions. Cell 156 950-962. (doi:10.1016/j.cell.2014.02.006)

Held T, Barakat AZ, Mohamed BA, Paprotta I, Meinhardt A, Engel W \& Adham IM 2011 Heat-shock protein HSPA4 is required for progression of spermatogenesis. Reproduction 142 133-144. (doi:10.1530/REP-11-0023)

Hobbs RM, Fagoonee S, Papa A, Webster K, Altruda F, Nishinakamura R, Chai L \& Pandolfi PP 2012 Functional antagonism between Sall4 and Plzf defines germline progenitors. Cell Stem Cell 10 284-298. (doi:10.1016/.j.stem.2012.02.004)

Huang H \& Tindall DJ 2011 Regulation of FOXO protein stability via ubiquitination and proteasome degradation. Biochimica et Biophysica Acta 1813 1961-1964. (doi:10.1016/j.bbamcr.2011.01.007)

Kluin PM \& de Rooij DG 1981 A comparison between the morphology and cell kinetics of gonocytes and adult type undifferentiated spermatogonia in the mouse. International Journal of Andrology 4 475-493. (doi:10. 1111/j.1365-2605.1981.tb00732.x)

Kops GJ, de Ruiter ND, De Vries-Smits AM, Powell DR, Bos JL \& Burgering BM 1999 Direct control of the Forkhead transcription factor AFX by protein kinase B. Nature 398 630-634. (doi:10.1038/19328)

Lee J, Kanatsu-Shinohara M, Inoue K, Ogonuki N, Miki H, Toyokuni S, Kimura T, Nakano T, Ogura A \& Shinohara T 2007 Akt mediates selfrenewal division of mouse spermatogonial stem cells. Development 134 1853-1859. (doi:10.1242/dev.003004

Meng X, Lindahl M, Hyvönen ME, Parvinen M, de Rooij DG, Hess MW, Raatikainen-Ahokas A, Sainio K, Rauvala H, Lakso M et al. 2000 Regulation of cell fate decision of undifferentiated spermatogonia by GDNF. Science 287 1489-1493. (doi:10.1126/science.287.5457.1489)
Nakagawa T, Sharma M, Nabeshima Y, Braun RE \& Yoshida S 2010 Functional hierarchy and reversibility within the murine spermatogenic stem cell compartment. Science 328 62-67. (doi:10.1126/science.1182868)

Naughton CK, Jain S, Strickland AM, Gupta A \& Milbrandt J 2006 Glial cell-line derived neurotrophic factor-mediated RET signaling regulates spermatogonial stem cell fate. Biology of Reproduction 74 314-321. (doi:10.1095/biolreprod.105.047365)

Ngo D, Cheng Q, O'Connor AE, De Boer KD, Lo CY, Beaulieu E, Seram MD, Hobbs RM, O'Bryan MK \& Morand EF 2013 Glucocorticoid-induced leucine zipper (GILZ) regulates testicular FOXO1 activity and spermatogonial stem cell (SSC) function. PLoS ONE 8 e59149. (doi:10.1371/ joumal.pone.0059149)

Nyamsuren G, Kata A, Xu X, Raju P, Dressel R, Engel W, Pantakani DV \& Adham IM 2014 Pelota regulates the development of primitive endoderm through activation of bone morphogenetic protein (BMP) signaling. Stem Cell Research 13 61-74. (doi:10.1016/i.scr.2014.04.011)

Oatley JM, Avarbock MR, Telaranta AI, Fearon DT \& Brinster RL 2006 Identifying genes important for spermatogonial stem cell self-renewal and survival. PNAS 103 9524-9529. (doi:10.1073/pnas.0603332103)

Pedersen K, Canals F, Prat A, Tabernero J \& Arribas J 2014 PELO negatively regulates HER receptor signaling and metastasis. Oncogene 33 1190-1197. (doi:10.1038/onc.2013.35)

Puri P, Phillips BT, Suzuki H, Orwig KE, Rajkovic A, Lapinski PE, King PD Feng GS \& Walker WH 2014 The transition from stem cell to progenitor spermatogonia and male fertility requires the SHP2 protein tyrosine phosphatase. Stem Cells 32 741-753. (doi:10.1002/stem.1572)

Ragan MA, Logsdon JM Jr, Sensen CW, Charlebois RL \& Doolittle WF 1996 An archaebacterial homolog of Pelota, a meiotic cell division protein in eukaryotes. FEMS Microbiology Letters 144 151-155. (doi:10.1111/ j.1574-6968.1996.tb08522.x)

Sariola H \& Saarma M 2003 Novel functions and signalling pathways for GDNE, Journal of Cell Science 1163855-3862 . (doi:10.1242/jcs.00786)

Shamsadin R, Adham IM, von Beust G \& Engel W 2000 Molecular cloning expression and chromosome location of the human Pelota gene PELO. Cytogenetics and Cell Genetics 90 75-78. (doi:10.1159/000015667)

Shamsadin R, Adham IM \& Engel W 2002 Mouse pelota gene (Pelo): cDNA cloning, genomic structure, and chromosomal localization. Cytogenetic and Genome Research 97 95-99. (doi:10.1159/000064059)

Shao S, von der Malsburg K \& Hegde RS 2013 Listerin-dependent nascent protein ubiquitination relies on ribosome subunit dissociation. Molecular Cell 50 637-648. (doi:10.1016/j.molcel.2013.04.015)

Shoemaker CJ \& Green R 2011 Kinetic analysis reveals the ordered coupling of translation termination and ribosome recycling in yeast. PNAS 108 E1392-E1398. (doi:10.1073̦/onas.1113956108)

Simon L, Ekman G, Tyagi G, Hess R, Murphy KM \& Cooke P 2007 Common and distinct factors regulate expression of mRNA for ETV 5 and GDNF, Sertoli cell proteins essential for spermatogonial stem cell maintenance. Experimental Cell Research 313 3090-3099. (doi:10.1016/j.yexcr.2007.05.002)

Singh SR, Burnicka-Turek O, Chauhan C \& Hou SX 2011 Spermatogonial stem cells, infertility and testicular cancer. Journal of Cellular and Molecular Medicine 15 468-483. (doi:10.1111/j.1582-4934.2010.01242.x)

Tsuboi T, Kuroha K, Kudo K, Makino S, Inoue E, Kashima I \& Inada T 2012 Dom34:Hbs1 plays a general role in quality-control systems by dissociation of a stalled ribosome at the $3^{\prime}$ end of aberrant mRNA. Molecular Cell 46 518-529. (doi:10.1016/j.molcel.2012.03.013)

Xi R, Doan C, Liu D \& Xie T 2005 Pelota controls self-renewal of germline stem cells by repressing a Bam-independent differentiation pathway. Development 132 5365-5374. (doi:10.1242/dev.02151)

Yoshida S, Sukeno M, Nakagawa T, Ohbo K, Nagamatsu G, Suda T \& Nabeshima Y 2006 The first round of mouse spermatogenesis is a distinctive program that lacks the self-renewing spermatogonia stage. Development 133 1495-1505. (doi:10.1242/dev.02316)

Received 1 August 2014

First decision 30 August 2014

Revised manuscript received 4 November 2014

Accepted 2 December 2014 


\subsection{Pelota regulates the development of extraembryonic endoderm through activation of bone morphogenetic protein (BMP) signaling}

In this part of the work, we found that Pelo deficiency did not markedly affect the selfrenewal of ESCs or lineage commitment in teratoma assays, while their differentiation into extraembryonic endoderm (ExEn) was severely compromised in EBs. Furthermore, we found that forced expression of Pelo in ESCs resulted in spontaneous differentiation towards the ExEn lineage. At molecular level, decreased activity of the BMP signaling pathway was observed in Pelo-null embryoid bodies (EBs). In vivo studies showed that PELO was not required for the induction of ExEn development, but rather for the maintenance or terminal differentiation of ExEn. Moreover, Pelo-null fibroblasts failed to reprogram toward ind uced pluripotent stem cells (iPSCs) due to inactivation of BMP signaling and impaired mesenchymal-to-epithelial transition. The analysis of $\mathrm{Pelo}^{\mathrm{F} /-} \mathrm{BRE}$ FFLuc and $\mathrm{Pelo}^{\Delta /-} \mathrm{BRE}$ FFLuc EBs showed that the mutant PELO $^{\Delta /-}$ EBs produced extracellular modulators of BMP signaling activity. Also we showed the conserved function of PELO in RNA quality control mechanism in murine ESCs. Collectively, our results indicate that PELO plays an important role in the establishment of pluripotency and differentiation of ESCs into ExEn lineage through activation of BMP signaling.

Authors: Gunsmaa Nyamsuren, Aleksandra Kata, Xingbo Xu, Priyadharsini Raju, Ralf Dressel, Wolfgang Engel, D.V. Krishna Pantakani, Ibrahim M. Adham

Status: Published in Ste m Cell Research, 2014, 13: 61-74.

\section{Impact factor: 3.912.}

\section{Author contributions to the work:}

1. Gunsmaa Nyamsuren: Conception and design of experiments, performed the experiments including identification of PELO expression in undifferentiated ESC and differentiated EBs, and embryos, analysis of differentiation potential of Pelo-deficient ESCs, over-expression studies, sample and data collection, data analysis, data interpretation, involved in manuscript preparation.

2. Aleksandra Kata: Participated in generation of Pelo conditional knockout mouse, primary studies of Pelo-deficient ESCs and Annexin-V apoptosis assay. 
3. Xingbo Xu: Performed the reprogramming of Pelo-deficient fibroblasts, PCR array and data analysis.

4. Priyadharsini Raju: Involved in the verification of the affected signaling pathway and consequence of Pelo depletion on the activity of BMP signaling, by analyzing a BMP responsive reporter cell line, proofreading the manuscript.

5. Ralf Dressel: Performed teratoma formation assay, cell cycle analysis, data analysis.

6. Wolfgang Engel: Conception and design of experiments, interpretation of the data, gave critical review of the manuscript.

7. D.V. Krishna Pantakani: Conception and design of experiments, interpretation of the data, data analysis, helped in drafting the manuscript.

8. Ibrahim M. Adham: Conception and design of experiments, coordination and helped to draft the manuscript. 


\title{
Pelota regulates the development of extraembryonic endoderm through activation of bone morphogenetic protein (BMP) signaling
}

\author{
Gunsmaa Nyamsuren $^{\mathrm{a}, 1}$, Aleksandra Kata ${ }^{\mathrm{a}, 1}$, Xingbo Xu ${ }^{\mathrm{a}}$, \\ Priyadharsini Raju ${ }^{a}$, Ralf Dressel ${ }^{b}$, Wolfgang Engel ${ }^{a}$, \\ D.V. Krishna Pantakani ${ }^{a}$, Ibrahim M. Adham ${ }^{a, *}$ \\ ${ }^{a}$ Institute of Human Genetics, University of Göttingen, D-37073 Göttingen, Germany \\ ${ }^{b}$ Department of Cellular and Molecular Immunology, University of Göttingen, D-37075 Göttingen, Germany
}

Abstract Pelota(Pelo $)$ is ubiquitously expressed, and its genetic deletion in mice leads to embryonic lethality at an early post-implantation stage. In the present study, we conditionally deletedPeloand showed that PELO deficiency did not markedly affect the self-renewal of embryonic stem cells (ESCs) or their capacity to differentiate in teratoma assays. However, their differentiation into extraembryonic endoderm (EXEn) in embryoid bodies (EBs) was severely compromised. Conversely, forced expression ofPeloin ESCs resulted in spontaneous differentiation toward the ExEn lineage. Failure ofPelo-deficient ESCs to differentiate into ExEn was accompanied by the retained expression of pluripotency-related genes and alterations in expression of components of the bone morphogenetic protein (BMP) signaling pathway. Further experiments have also revealed that attenuated activity of BMP signaling is responsible for the impaired development of ExEn. The recovery of ExEn and down-regulation of pluripotent genes in BMP4-treated Pelo-null EBs indicate that the failure of mutant cells to down-regulate pluripotency-related genes in EBs is not a result of autonomous defect, but rather to failed signals from surrounding ExEn lineage that induce the differentiation program. In vivo studies showed the presence of ExEn inPelo-null embryos at E6.5, yet embryonic lethality at E7.5, suggesting that PELO is not required for the induction of ExEn development, but rather for ExEn maintenance or for terminal differentiation toward functional visceral endoderm which provides the embryos with growth factors required for further development. Moreover,Pelo-null fibroblasts failed to reprogram toward induced pluripotent stem cells (iPSCs) due to inactivation of BMP signaling and impaired mesenchymal-to-epithelial transition. Thus, our results indicate that PELO plays an important role in the establishment of pluripotency and differentiation of ESCS into ExEn lineage through activation of BMP signaling.

(c) 2014 The Authors. Published by Elsevier B.V. This is an open access article under the CC BY license (http://creativecommons.org/licenses/by/3.0/).

\footnotetext{
* Corresponding author at: Institute of Human Genetics, Heinrich-Düker-Weg 12, D-37073 Göttingen, Germany. Fax: +49 551399303.

E-mail address:iadham@gwdg.de(I.M. Adham).

1 These authors contributed equally to this work.
} 


\section{Introduction}

Two developmental processes take place during preimplantation in the development of mammalian embryos. The outer cells of the morula differentiate into a trophoectoderm (TE) lineage, whereas the inside cells become the inner cell mass (ICM). Further development involves the specification of the ICM into primitive endoderm ( $P r E$ ), located on the outside of the ICM, and into epiblast (EPI) that differentiates during later embryonic development into all three germ layers, including primordial germ cells (Cockburn and Rossant, 2010). Around the time of implantation, PrE gives rise to extraembryonic endoderm (ExEn), which contributes to visceral (VE) and parietal endoderm (PE) (Tam and Loebel, 2007; Plusa et al., 2008). VE and PE enclose and provide the developing embryo with nutritive support and molecular signals that are essential for cell fate decisions and axial pattern initiation (Bielinska et al., 1999; Yamamoto et al., 2004). Genetic ablation studies of genes involved in the development of PrE or its derivatives revealed an early embryonic lethality (Molkentin et al., 1997; Morrisey et al., 1998; Koutsourakis et al., 1999; Yang et al., 2002). Recent reports revealed that the differential expression of the pluripotency-related gene Nanog and GATA family members Gata4 and Gata6 in ICM cells is responsible for cell fate decisions regarding differentiation into EPI and PrE, respectively (Chazaud et al., 2006). These results confirm previous findings that showed the requirement of Nanogfor the establishment of EPI and for the suppression of PrE differentiation (Mitsui et al., 2003), whereas Gata4 and Gata6 are crucial for the development of PrE and its derivatives (Molkentin et al., 1997; Morrisey et al., 1998; Koutsourakis et al., 1999; Cai et al., 2009).

Embryonic stem cells (ESCs), the in vitro counterpart of ICM cells, are pluripotent and have the potential to differentiate into all cell lineages of the early embryo; hence, they are regarded as a valuable tool to understand the molecular mechanisms governing early embryonic development (Niwa, 2010). The embryoid body (EB) that is formed during ESC differentiation in floating culture critically mimics the pre- and post-implantation developmental stages of the embryo (Doetschman et al., 1985). This system was successfully exploited to study and understand the ExEn loss phenotype seen in a Gata6-knockout mouse model (Capo-Chichi et al., 2005).

PELO is highly conserved in eukaryotes. In yeast, the PELO-ortholog Dom34 and its interacting protein $\mathrm{Hbs} 1$ are the core components of the newly described RNA surveillance mechanism called No-Go decay (NGD) (Doma and Parker, 2006). NGD recognizes mRNAs on which the ribosome is stalled at a stable stem-loop, rare codon, or pseudoknot, triggering the endonucleolytic cleavage of these mRNAs (Graille et al., 2008; Chen et al., 2010). Despite central function of the Dom34:Hbs1 complex in NGD, neither of these proteins is essential for yeast survival (Carr-Schmid et al., 2002). In contrast, the deletion of Peloresults in embryonic lethality beyond $6.5 \mathrm{dpc}$ in mice. The in vitro culture of Pelo ' blastocysts revealed a failure of ICM to expand and give rise to ESCs, suggesting that PELO might be involved in the regulation of the cell cycle or the self-renewal of a pluripotent ICM or ESCs (Adham et al., 2003). The role of PELO in the control of germ stem cell self-renewal has been described in the ovary of Drosophila melanogaster(Xi et al., 2005).
Here, we generated a conditional knockout mouse model to investigate the role of PELO in early embryonic development and ESC pluripotency. We report that PELO is dispensable for self-renewal of ESCs but is required for ESC differentiation into ExEn. At the molecular level, we show that the decreased activity of BMP signaling is responsible for the impaired differentiation of ExEn in Pelo-deficient EBs.

\section{Material and methods}

\section{Generation of conditional Pelo knockout mice}

The Pelo ${ }^{F}$ targeting construct was generated in the pPNT4 vector. In thePelo ${ }^{F}$ targeting construct, two loxP sites were inserted into intron 1 and the $3^{\prime}$-flanking region of Pelo to allowCre-mediated recombination and excision of exons 2 and 3 containing the coding sequences of Pelo. The 6.7- and 4.6-kb long $5^{\prime}$ - and $3^{\prime}$-flanking homologous arms, respectively, were cloned into the targeting construct (Suppl. Fig. 1A). The targeting vector was linearized with Notl and used for transfection of RI ESCs. Neomycin-resistant ESC clones were checked for homologous recombination by southern blotanalysis. External probes (P1 and P2 in Suppl. Fig. 1A) were used for hybridization of southern blots containing EcoRIandBsrGI-digested DNA (Suppl. Figs. 1B, C). To confirm the absence of the additional insertion of targeting construct in homologous recombinant ESCs, blots containingAsel-digested DNA were probed with neomycin fragment (Suppl. Fig. 1D). Cells from two correctly targeted ESC clones were microinjected into C57BL/6J blastocysts. Chimeric founders were mated with $\mathrm{C} 57 \mathrm{BL} / 6 \mathrm{~J}$ mice to generate heterozygousPelo $\mathrm{F/+}$ mice, which were intercrossed with conventionalPelo ${ }^{+/-}$mice to produce heterozygous Pelo $\mathrm{F}^{\mathrm{T}-}$ mice. The Rosa26CreERT2 knock-in (Hameyer et al., 2007) and transgenicElla-Cremice (Lakso et al., 1996) were bred withPelo ${ }^{\mathrm{Fl}-}$ mice to generate inducible and constitutive Pelo-KO mice, respectively. Genotyping of mice was carried out by PCR amplification (Suppl. Fig. 1E). Primer sequences are listed in Suppl. Table 1. All animal experiments were reviewed and approved by the Institutional Animal Care and Use Committee of the University of Göttingen.

\section{Cell culture and teratoma formation assay}

layers in LIF-supplemented medium as described previously (Wurst and Joyner, 1993). For differentiation of ESCs into EBs, a single-cell suspension of ESCs was incubated for $30 \mathrm{~min}$ on uncoated culture dishes to remove feeder cells. Afterwards, ESCs $\left(1 \times 10^{5} \mathrm{cells} / \mathrm{cm}^{2}\right)$ were plated onto bacteriological dishes and grown in ESC medium without LIF. After 4 days of culture, EBs were fed with fresh medium every second day and harvested at the indicated time points. Alternatively, MEF-free ESCs were plated on Aggriwell plates (STEMCELL Technologies) at a density of $1 \times 10^{5}$ cells/well. To determine whether the retinoic acid (RA) induces the ExEn differentiation inPelo-null EBs, ESCs were allowed to aggregate and grown with $1 \mu \mathrm{M}$ RA for 5 days. For culture of wild-type EBs with conditioned medium derived from Pelo-deficient EB cultures, Pelo ${ }^{\prime-}$ 
ESCs were seeded at $5 \times 10^{4}$ cells per $1 \mathrm{~cm}^{2}$ in Knockout ${ }^{\text {TM }}$ DMEM medium supplemented with $20 \%$ Knockout $^{\text {TM }}$ serum replacement (SR, Life Technology) on bacterial Petri dishes. After 5 days of EB cultures, supernatants were collected, filtered and used as a culture medium for EB formation of wild-type ESCs. After 6 days, wild-type EBs were collected and either fixed for immunohistological analysis or subjected for RNA isolation.

To determine the effect of BMP4 and Noggin on the development of ExEn, mutant Pelo ${ }^{1-}$ and control Pelo ${ }^{F /-}$ EBs were formed in serum replacement medium (SR) supplemented with either $20 \mathrm{ng} / \mathrm{ml}$ recombinant BMP4 (Life Technology) or $150 \mathrm{ng} / \mathrm{ml}$ recombinant Noggin (Life Technology), respectively.

To generate BMP responsive reporter cell line $\left(\mathrm{Pelo}^{\mathrm{F}}\right.$ / BRE-FFLuc), Pelo ${ }^{\mathrm{F} /}-\mathrm{ESC}$ were transfected with the reporter construct pBFIR containing BMP responsive element (BRE) driven Firefly luciferase gene (FFLuc) and SV40 promoter/ enhancer driven Renilla luciferase (RRLuc) gene (Yadav et al., 2012). The ESC clone (Pelo $F^{F /-}$ BRE-FFLuc) showing high FFLuc activity in response to $20 \mathrm{ng} / \mathrm{ml}$ recombinant BMP4 was selected and cultured in medium containing $1 \mu \mathrm{M} 4-\mathrm{OHT}$ to generatePelo ${ }^{1-}$ BRE-FFLuccell line. The parentalPelo ${ }^{F /}$ BRE-FFLucand thePelo ${ }^{1-}$ BRE-FFLucESCs were aggregated in SR medium for 5 days, and the resulting EBs were then treated for $12 \mathrm{~h}$ either with or without $20 \mathrm{ng} / \mathrm{ml}$ recombinant BMP4. In another assay, Pelo ${ }^{F /-}$ BRE-FFLuc EBs were cultured for $12 \mathrm{~h}$ with Pelo ${ }^{1-}$ EBs conditioned medium supplemented either with or without BMP4. Dual luciferase assay was carried out according to the manufacturer's recommendation (PJK GmbH, Kleinblittersdorf, Germany).

For teratoma formation assay, single-cell suspension of cultured ESCs in PBS $\left(4 \times 10^{6}\right.$ cells in $100 \mu \mathrm{l}$ PBS $)$ was subcutaneously injected into the flanks of immunodeficient $\mathrm{RAG2}^{-1-} \mathrm{gC}^{-1-}$ mice. After 4-7 weeks, teratomas were excised, fixed, and subjected to histological analysis.

\section{Generation of induced pluripotent stem cells}

We used Yamanaka factors (retroviral expression vectors for Oct3/4, Sox2, Klf4, and c-Myc) procured from Addgene to generate iPSCs, as previously described (Takahashi and Yamanaka, 2006). Briefly, MEFs isolated from transgenic Nanog-EGFP (Okita et al., 2007), Pelo ${ }^{\mathrm{F} /+}, \mathrm{Pelo}^{\mathrm{F} /-}$, and Pelo ${ }^{1-}$ MEFs were transduced with retroviral particles, as previously described (Xu et al., 2011). To establish iPSC lines, colonies that appeared after 10 days of virus infection were picked manually and cultured in 24-well plates under standard ESC culture conditions. For rescue experiments, Pelo ${ }^{\Delta /-}$ MEFs were transduced with retroviral particles expressingPeloin addition to Yamanaka factors.

\section{Generation of expression constructs}

Peloin wild-type ESCs was generated by PCR amplification of PelocDNA using primers Pelo-F and Pelo-R (Suppl. Table 3) and cloning into the Xhol site of the PCAG-IZ vector. The construct containing the stem loop-EGFP (pCAG-SL-EGFP-IZ) was generated by PCR amplification and cloning of EGFP cassette (lacking ATG-start codon) intoEcoRI/Sall-digested
pBluescript vector to yield pBluescript-EGFP. Sequences of primers (GFP-F and GFP-R) used for EGFP cassette amplification are provided in Supplementary Table S1. Next, the sense and anti-sense oligonucleotides SL-S and SL-AS (Suppl. Table 1) containing the sequences of ATG and stem-loop were annealed and cloned into the BamHI/ EcoRI-digested pBluescript-EGFP construct to generate pBluescript-SL-EGFP. Finally, theXhol/Sall fragment containing SL-EGFP fragment was cloned intoXhol-digested PCAGIZ vector to generate PCAG-SL-EGFP-IZ. The retroviral construct of Pelo (pMXs-Pelo) was generated by PCR amplification of PelocDNA using pcDNA 3.1-Myc-Pelo (Burnicka-Turek et al., 2010) as a template and cloning intoEcoRI restriction sites of the $\mathrm{pMX}$ vector.

\section{RNA isolation, RT-PCR, qRT-PCR, and northern blot analysis}

Total RNA was extracted using an RNeasy mini-kit (Qiagen, Germany) or NucleoSpin miRNA kit (Macherey-Nagel, Germany) by following the manufacturer's protocols. For mRNA expression analysis, $5 \mu \mathrm{g}$ total RNA was processed for cDNA synthesis using the SuperScript II system (Invitrogen, Germany). For miRNA quantification assays, $1 \mu \mathrm{g}$ total RNA was used for cDNA synthesis using the miScript II RT Kit (Qiagen). For qRT-PCR analysis, diluted CDNA (1:10) was used as a template in a QuantiFast SYBR Green (Qiagen) reaction and run in an ABI 7900HT Real-Time PCR System (Applied Biosystems). Expression data were first normalized to housekeeping genes (Hprt or Sdha) and represented as relative expression to one of the cell types. For northern blot analysis, $15 \mu \mathrm{g}$ total RNA was resolved on an agarose gel containing formaldehyde, transferred onto a nylon membrane, and hybridized with Pelo cDNA and EGFP probes (Shamsadin et al., 2002). All experiments were independently replicated at least two times. Primers used for RT-PCR and qRT-PCR analyses are listed in Supplementary Tables S2 and S3.

To assay Noggin mRNA stability in control and mutant cells, EBs were treated with $10 \mu \mathrm{g} / \mathrm{ml}$ of actinomycin $\mathrm{D}$, and total RNA was extracted after $0,0.5,2,4$, and $8 \mathrm{~h}$ of the treatment. Northern blots with RNAs isolated from ESCs and EBs were hybridized withNoggincDNA probe. Hybridization signals were quantified by ImageJ software $(\mathrm{NIH}$, Bethesda, MD, USA). Optic density of Noggin mRNA levels at each time point was normalized toElongation factor-2transcript levels.

\section{Cell proliferation, apoptosis and cell cycle analysis}

To determine cell proliferation, we used the CellTiter 96 AQueous Non-Radioactive Cell Proliferation Assay Kit (Promega, Madison, WI). Briefly, ESCs were plated at a density of 500 cells/ well in gelatin-coated 96-well plates. After 2, 4, and 6 days of culture, cell proliferation was measured after incubation with MTS reagent. The absorbance was detected at $490 \mathrm{~nm}$ with a Microplate Reader. Results are presented as the mean absorbance of three independent experiments.

To verify the apoptosis, single-cell suspensions were labeled for Annexin- $V$ and 7-amino-actinomycin D (7-AAD) staining using an Annexin V-PE Apoptosis Detection Kit I (BD 
Biosciences), following the manufacturer's instructions. After staining, flow cytometric measurements were performed on a FACSCalibur flow cytometer and analyzed with CellQuestPro software (BD Biosciences).

For cell cycle analysis, ESCs were trypsinized and washed with PBS followed by ethanol fixation at $20{ }^{\circ} \mathrm{C}$ for a minimum of $2 \mathrm{~h}$. After fixation, the cells were washed, resuspended in PBS containing $10 \mathrm{mg} / \mathrm{ml}$ propidium iodide $(\mathrm{PI})$ and $1 \mathrm{mg} / \mathrm{ml}$ RNase $\mathrm{A}$, and incubated at $37^{\circ} \mathrm{C}$ for $30 \mathrm{~min}$. After incubation, cells were measured on a FACSCalibur flow cytometer and analyzed after exclusion of cell doublets. All experiments were performed in three independent experiments.

\section{Immunostaining and alkaline phosphatase staining}

ESCs grown on cover slips were washed with phosphatebuffered saline (PBS) and fixed with $4 \%$ paraformaldehyde (PFA) at $4{ }^{\circ} \mathrm{C}$ for $30 \mathrm{~min}$. EBs were fixed with $4 \%$ PFA at $4{ }^{\circ} \mathrm{C}$ for $1 \mathrm{~h}$, washed with PBS, incubated with $30 \%$ sucrose at $4{ }^{\circ} \mathrm{C}$, embedded in OCT, and cryosectioned at a $10-\mu \mathrm{m}$ thickness. Deciduae were isolated at E6.5 and E7.5 from females of heterozygousPelo ${ }^{+/-}$breeding, fixed overnight in $4 \%$ PFA at $4{ }^{\circ} \mathrm{C}$, dehydrated and embedded in paraffin. Sections $(5 \mu \mathrm{m})$ were either stained with hematoxylin and eosin (H\&E) or subjected to immunohistological analysis. Cells or sections were permeabilized and blocked using PBS containing $0.1 \%$ Triton $\mathrm{X}-100$ and $1 \%$ goat serum for $1 \mathrm{~h}$. The primary antibodies were diluted in blocking buffer and incubated with cells or slides at $4{ }^{\circ} \mathrm{C}$ overnight. The next day, cells or slides were washed with PBS followed by incubation with secondary antibodies conjugated to fluorescent dyes. Images were acquired using an Olympus BX60 microscope (Olympus, Germany).

Cytochemical staining for alkaline phosphatase (AP) activity was performed using a Leukocyte Alkaline Phosphatase Kit (Sigma-Aldrich, Germany), according to the manufacturer's instructions.

\section{Western blotting}

Total protein isolation, separation by SDS-PAGE, and subsequent western blotting were performed as previously described (Xu et al., 2011). Antibodies used for western blot analysis and their sources are listed in Supplementary Table 4.

To determine the levels of Noggin in the conditioned medium, wild-type and Pelo-null EBs were cultured in SR medium. Conditioned medium was concentrated with Centrisart $\circledast$ I ultrafiltration unit (Sartorius, Germany). For semiquantitation of Noggin protein, equal amount of concentrates was loaded onto SDS/PAGE gel and blot was incubated with goat anti-mouse Noggin antibody (R\&D systems)

\section{TGF- $\beta$ /BMP PCR array}

A mouse TGF $\beta$ /BMP Signaling Pathway PCR array (SABiosciences, PAMM-035) was used to analyze the expression levels of BMP signaling pathway components in $\mathrm{PelO}^{\mathrm{F} /-}$ and $\mathrm{PelO}^{\Delta /-}$ EBs. Briefly, total RNA was isolated fromPelo ${ }^{F /-}$ and $\mathrm{PelO}^{\Delta /-}$ EBs after 5 days of ESC culture under differentiation conditions as described above. Subsequently, $5 \mu \mathrm{g}$ total RNA was used for first-strand CDNA synthesis with the RT2 first strand kit (Qiagen, Germany). The PCR array was carried out following the manufacturer's instructions using the readyto-use $\mathrm{RT}^{2}$-qPCR master mix (RT2-SYBR ${ }^{2}$ Green/Fluorescein qPCR master mix, SABiosciences, Germany). Twentyfive microliters of the experimental cocktail was added into each well containing pre-dispensed, gene-specific primer pairs and run on an $A B I 7900 \mathrm{HT}$ fast quantitative PCR system. Data analysis was performed using the web-based standard RT PCR array suite (SABiosciences, Germany).

\section{Statistical analysis}

All qPCR data for RNA expression analysis (two or more biological replicates) were calculated using the standard curve method. A two-way ANOVA (GraphPad Prism 4.0) test was used to obtain calculations of statistical significance.

\section{Results}

\section{PELO is essential for the development of ExEn lineage}

To elucidate the function of Pelo in pluripotency and ESC differentiation potential, we generated a conditional Pelo construct containing two loxP elements flanking exons 2 and 3 of Pelo (Suppl. Fig. 1A). A floxed allele $\left(\mathrm{Pelo}^{F}\right)$ was generated in mouse ESCs by homologous recombination (Suppl. Figs. 1A-D). Injection of $\mathrm{Pelo}^{\mathrm{F} /+} \mathrm{ESCS}$ into blastocysts resulted in chimeric mice, and further breeding with conventional heterozygous $\mathrm{PelO}^{+/-}$established $\mathrm{PelO}^{\mathrm{F} /}$, whereas inbreeding with $\mathrm{Pelo}^{\mathrm{Fl+}}$ established Pelo ${ }^{F / F}$ animals. The Pelo ${ }^{F / F}$ and $\mathrm{PelO}^{F /-}$ mice appeared normal and were fertile, indicating that the insertion of loxP and the neo-cassette did not disrupt the Pelo locus. Genetic depletion of Pelo in one cell-stage embryos was accomplished by breeding Pelo ${ }^{F / F}$ with Ella-Cre-deleter mice and an F1 generation intercross of Pelo ${ }^{1+}$ Ella-Cre mice. Similar to the post-implantation lethality of conventional Pelo ${ }^{-1-}$ embryos, genotyping of more than 100 embryos at E8.5 did not lead to the identification of any homozygous Pelo ' embryos (data not shown), indicating that deletion of the floxed region in Pelo' embryos at the one-cell stage results in lethality.

To examine the consequence of Pelo deletion on ESC pluripotency and development of pre-implantation embryos, Pelo ${ }^{F /-}$ mice were crossed with mice harboring a knock-in Rosa 26-CreERT2 allele to obtain mice of the compound genotypePelo ${ }^{F /}$ CreERT2andPelo F/F CreERT2.

We established Pelo ${ }^{F /-}$ CreERT2 ESC lines that were derived from the ICM of blastocysts ofPelo ${ }^{\mathrm{F} /}$ CreERT2mice interbreeding. Upon 4-hydroxytamoxifen (4-OHT) treatment, Cre-mediated deletion of floxed Pelo generated a null allele (Pelo), as verified by PCR (Suppl. Fig. 1E). Northern and western blot analyses confirmed the absence of the Pelo transcript and protein in Pelo ${ }^{1-}$ ESCs (Suppl. Figs. 1F, G). Pelo-deficient ESCs exhibited normal colony morphology and unlimited proliferation in culture, but exhibiting slightly slower growth (Suppl. Fig. 2A). However, no alterations in the proportion of apoptotic cells were 
observed when cells were analyzed based on Annexin- $V$ and 7-aminoactinomycin $D$ (7-AAD) staining by fluorescenceactivated cell sorting (FACS) (Suppl. Fig. 2B). Furthermore, no significant differences were observed in the analyzed cell cycle parameters between control andPelo-null ESCs (Suppl. Fig. 2C). The finding that the deletion of Peloin established ESC lines did not significantly affect their viability was surprising, given that the conventionalPelo ${ }^{-1-} \mathrm{ICM}$ failed to expand its pluripotent cell population (Adham et al., 2003). Therefore, we studied the differentiation potential of mutant ESCs in formed embryoid bodies (EBs). In contrast with control Pelo ${ }^{F /-}$ EBs, most of the mutant Pelo /- EBs failed to form a distinct outer layer of ExEn (Fig. 1A). We have determined the expression of several pluripotency and ExEn markers in control and mutant ESCs and EBs. No significant differences in expression levels of pluripotency genes were observed between mutant and control ESCs (Fig. 1C). The attenuated levels of c-Myc expression in mutant ESCs compared to that in control ESCs may explain the slightly slower growth of Pelo-deficient ESCs. Expression of pluripotency genes was markedly reduced in control Pelo ${ }^{F /}$ EBs, as expected (Fig. 1C). In contrast, pluripotency genes persist to express at high levels inPelo -deficient EBs, even after 15 days of differentiation (Fig. 1C). Immunoblot analysis further confirmed the expression of OCT4 (also known as POU5F1) in Pelo-deficient EBs (Fig. 1B). Furthermore, re-plating of cells derived from 15-day-old Pelo ${ }^{1-}$ EBs formed typical ESC colonies and expressed OCT4, whereas control Pelo ${ }^{F /}$ cells failed to form colonies (Suppl. Figs. 3A-D).
To confirm the impaired differentiation of ExEn in mutant Pelo ${ }^{1-}$ EBs, we investigated the expression levels of marker genes for differentiation of ExEn lineage. As shown inFig. 1D, expression levels of ExEn marker genesGata6,Gata4,Hnf4, $A f p$, and Dab2 were significantly reduced in mutant EBs. Immunostaining of histological sections of EBs revealed that expression of PELO and ExEn markers DAB2 and GATA4 is localized on the outer layer of control EBs, whereas PELO-, DAB2-, and GATA4-positive cells were mainly lacking in mutant EBs (Fig. 2A). Collectively, these results indicate a requirement of PELO for the development of ExEn lineage. We then investigated the consequence ofPelodeficiency on the temporal expression of genes associated with pluripotency, early and late stages of ExEn differentiation during EB formation (Fig. 2B). No significant differences in expression levels of pluripotency-related genes, Nanog and Oct4, in mutant and control EBs after 2 and 3 days of culture were observed. Similarly, there were no differences in the expression of early ExEn markers, Gata4 and Gata6, after 3 days. After 4 days of EB formation, the expression of Nanog andOct 4was sharply down-regulated in control EBs compared to that in mutant EBs. In contrast, expression levels ofGata4 andGata6were significantly elevated in control EBs, but not in mutant EBs, after 5 days of culture (Fig. 2B). UnlikeGata4 undGata6, the expression of $\mathrm{Hnf} 4$, a late ExEn marker, was first activated in control EBs after 5 days of culture and subsequently enhanced. However, expression of $\mathrm{Hnf4}$ remained at low levels in Pelo-deficient EBs (Fig. 2B). The observed expression changes of early and late ExEn markers
A

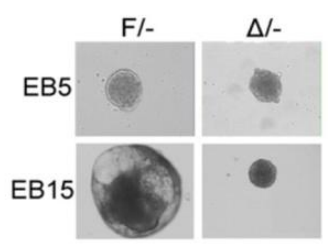

B

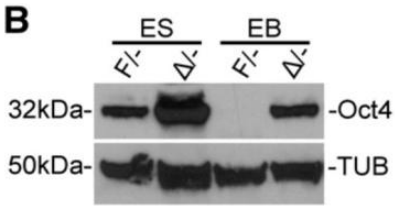

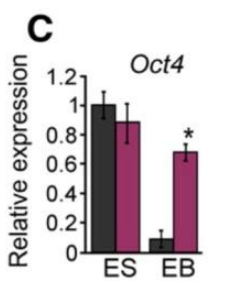
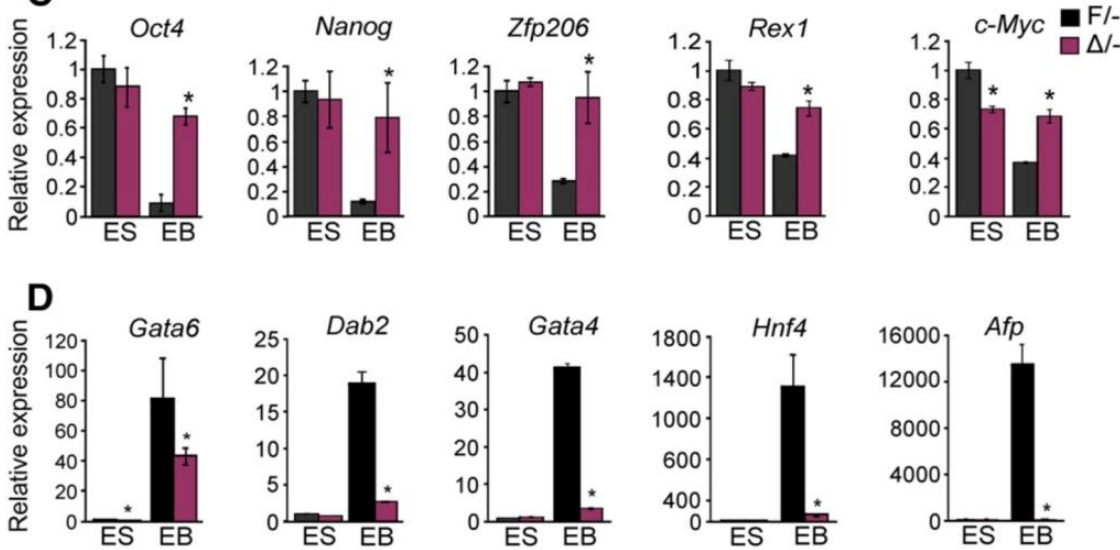

Figure 1 Failure ofPelo-deficient ESCs to differentiate into ExEn lineage. (A) Phase-contrast micrographs of controlPelo ${ }^{\mathrm{F} /-}$ and mutantPelo ${ }^{1-}$ EBs on days 5 (EB5) and 15 (EB15) of differentiation. (B) Immunoblot for expression of OCT4 inPelo ${ }^{\mathrm{F} /-}$ andPelo ${ }^{1-}$ ESCs and EBs. (C) Quantitative real-time PCR analysis for the expression of pluripotency marker genes inPelo ${ }^{F /-}$ andPelo ${ }^{1-}$ ESCs and EBs on day 15 of differentiation. (D) Quantitative RT-PCR analysis of the expression of ExEn markers inPelo ${ }^{\mathrm{F} /-}$ andPelo ${ }^{1-}$ ESCs and EBs. Values of expression levels in $C$ and $D$ normalized toHprtorSdhaare presented as mean \pm SD of three experiments. Transcript levels of control ESCs were expressed as 1.0. *, significantly different from control; $p<0.05$. 

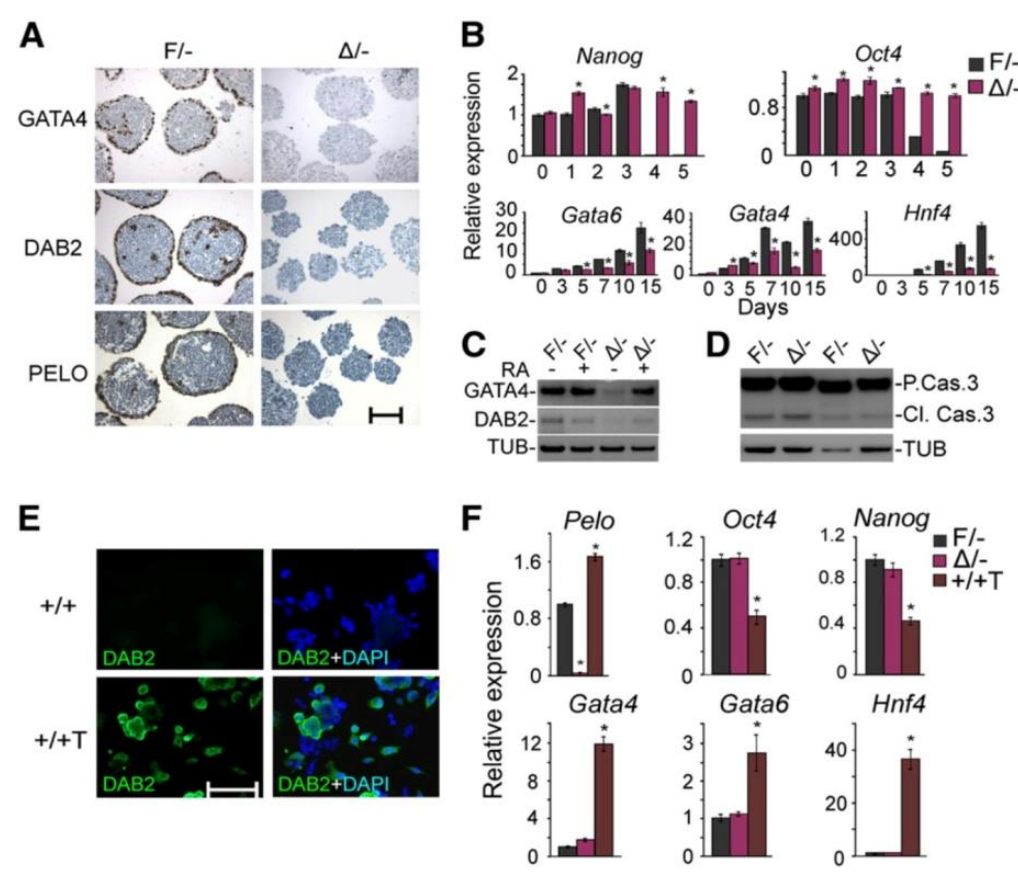

Figure 2 Expression of Peloand ExEn markers in controlPelo ${ }^{\mathrm{F} /-}$ EBs, mutant Pelo ${ }^{1-}$ EBs, andPelo-overexpressing ESCs. (A) Paraffin sections of Pelo $\mathrm{F}^{\mathrm{F}-}$ andPelo ${ }^{1-}$ EBs on day 10 of differentiation were immunostained with GATA4, DAB2, and PELO antibodies. Scale bars in A: $20 \mu \mathrm{m}$. (B) Quantitative RT-PCR analysis for the temporal expression of pluripotency-related and ExEn markers inPelo ${ }^{\mathrm{F} /}{ }^{-}$andPelo ${ }^{\prime-}$ cells during EB formation. Expression levels normalized to Hprt are presented as mean \pm SD of three experiments. Transcript levels of control cells at day 0 of differentiation were expressed as 1.0. *, significantly different from control; $p<0.05$. (C) Immunoblot analysis for the expression of GATA4 and DAB2 inPelo ${ }^{F /-}$ andPelo ${ }^{1-} \mathrm{EBs}$, which were formed in the absence ( ) or presence (+) of retinoic acid (RA). (D) Total proteins isolated from EBs after 10 days of culture were analyzed by immunoblotting for the expression of pro-caspase (P. cas.3) and cleaved caspase $3(\mathrm{Cl}$. Cas.3). (E) Wild-type ESCs $(+/+)$ andPelo-overexpressing ESCs $(+/+\mathrm{T})$ were cultured in the presence of LIF, fixed, and immunostained with anti-DAB2 antibodies. The nuclei were stained with DAPI. (F) Expression levels ofPelo, pluripotency and ExEn marker genes inPelo ${ }^{\mathrm{F}-}$, Pelo ${ }^{1-}$ andPelo-overexpressing $\left(\right.$ Pelo ${ }^{+1+T}$ ) ESCs were determined by qRT-PCR. Values of expression levels normalized toHprtare presented as mean \pm SD of three experiments. Transcript levels of control ESCs were expressed as 1.0. *, significantly different from control; $p<0.05$. Scale bars in E: $100 \mu \mathrm{m}$.

during EB formation suggest that the development of the ExEn is although induced in mutant EBs, but is not maintained to late stages of EB formation. We further investigated whether the impaired development of ExEn inPelo-deficient EBs can be restored by the activation of retinoic acid (RT) signaling pathway. As shown inFig. $2 \mathrm{C}$, retinoic acid induces expression of GATA4 and DAB2 inPelo-null EBs in the same extent as in control EBs, indicating that the RA treatment stimulates ExEn differentiation in Pelo-null EBs. To examine whether the impaired development of Pelo-null EBs is a result of increased apoptosis, we monitored apoptotic cell death by analyzing the levels of cleaved caspase 3 in control and mutant EBs after 10 days of culture. Western blot analysis revealed no marked difference in the protein levels of cleaved caspase 3 in both control and mutant EBs (Fig. 2D).

These results prompted us to examine whether overexpression of Peloin wild-type ESCs induces a differentiation program toward ExEn.Pelo ${ }^{+/+}$ESCs were stably transfected with a pCAG-Pelo-IZ construct containingPelocDNA under the control of CAG promoter. In contrast to typical ESC morphology of empty vector-transfected cells, mostPelo-transfected colonies displayed closely apposed, flattened cells similar to the morphology of ExEn cells (Jetten et al., 1979) and were positive for DAB2 (Fig. 2E). Quantitative RT-PCR revealed that expression levels of Pelo in pCAG-Pelo-IZ-transfected cells were 1.7-fold higher than that of empty vectortransfected cells (Fig. 2F). In line with the DAB2 expression, the expression of Gata4,Gata6and $\mathrm{Hnf} 4$ was strongly induced inPelo-overexpressing cells (Fig. 2F). To determine whether increased expression of Pelo in ESCs restricts their fate to an ExEn lineage, expression of pluripotency genes Oct4 and Nanog was examined. As shown in Fig. 2F, the expression of pluripotency marker genes was significantly reduced in Pelo-overexpressing cells, indicating that increased Pelo expression induces the differentiation of ESCs toward an ExEn lineage.

To assess the differentiation capacity of mutant ESCs in teratoma formation, we compared the teratoma-forming ability of control and mutant ESCs in immunodeficient Rag2 $^{-1-} \mathrm{cg}{ }^{\prime}$ mice. Both Pelo ${ }^{F /-}$ and Pelo ${ }^{\Delta /-}$ ESCs formed teratomas containing tissues derived from all three germ layers (Suppl. Fig. S4). These results revealed the capacity ofPelo-deficient ESCs to differentiate into cell lineages of the three germ layers in a teratoma assay. 
Disrupted development of ExEn in EBs derived from mutant ESCs led us to investigate the development of ExEn in Pelo-null embryos. Since Pelo-deficient embryos died between E6.5 and E7.5 (Adham et al., 2003), we have performed immunohistological analysis on sections of E6.5 and E7.5 embryos derived from breeding of heterozygous $\mathrm{PelO}^{+/-}$animals. As expected, PELO was ubiquitously expressed in control embryos, but was undetectable in Pelo ${ }^{-1-}$ embryos (Suppl. Fig. 5A). Mutant E6.5 embryos were markedly smaller than their heterozygous and wild-type littermates. Although ExEn is formed inPelo-deficient E6.5 embryos as indicated by the expression of GATA4 and DAB2, the development of Pelo-null embryos at E7.5 was severely affected, a likely consequence of the absence of ExEn (Suppl. Figs. 5A, B). These results suggest that PELO is not required for the formation of ExEn, but rather for the maintenance of ExEn or for terminal differentiation to functional ExEn that provides the embryo with growth factors required for early embryonic development.

\section{PELO deficiency attenuates the activity of BMP signaling in EBs}

Studies in Drosophila showed that PELO regulates the differentiation of germ stem cells in the ovary through BMP signaling ( $\mathrm{Xi}$ et al., 2005). Interestingly, defects in a PrE-derived lineage, VE, and subsequent cavitation abnormalities were observed during EB formation of ESCs treated with $B M P$ antagonists or ESCs overexpressing dominant-negative BMPR1b receptor (Coucouvanis and Martin, 1999; Conley et al., 2007; Rong et al., 2012). These observations, together with impaired ExEn development seen inPelo-deficient EBs, led us to investigate the mRNA expression profile of genes involved in TGF- $\beta$ /BMP signaling in control and mutant EBs. Gene expression analysis for TGF- $\beta$ /BMP signaling components in a PCR array revealed that 22 genes exhibit at least a 3 -fold difference in gene expression between Pelo-deficient and control EBs (Suppl. Fig. 6 and Table 5). The changes in mRNA levels of some differentially expressed genes were verified by qRT-PCR (Fig. 3A). The mRNA levels of several BMP ligand genes (Bmp-4 and -6$)$ were significantly down-regulated in Pelo-deficient EBs compared with control EBs (Fig. 3A). Additionally, the expression of several BMP-target genes, including $I d 1$ and $I d 3$, was down-regulated in Pelo ${ }^{1-}$ EBs, confirming the decreased activity of BMP signaling in mutant EBs (Fig. 3A). In contrast, genes encoding Noggin and Lefty1, which are known as potent antagonists of BMP and Nodal/ Activin signaling, respectively, were expressed highly in mutant EBs to a level approximately more than $4-8$ folds in control EBs (Fig. 3A). The decreased activity of BMP signaling inPelo-deficient EBs was further confirmed by western blot analysis of phosphorylated Smad1/5 (Fig. 3B).

The strong up-regulation of NoggininPelo-deficient EBs was particularly interesting, because overexpression of Noggin has been shown to affect the ExEn development (Rong et al., 2012). Accordingly, we examined the effect of conditioned medium collected from Pelo-deficient EB culture on the differentiation of wild-type ESCs. While the expression of ExEn-specific markers was not significantly increased in Pelo-deficient EBs that were cultured in conditioned medium collected from wild-type EB culture (data not shown), culture of wild-type ESCs with conditioned medium collected fromPelo-deficient EB culture resulted in a significant decrease in expression levels of ExEn-specific markers (Fig. 3C). Moreover, we observed a decreased expression of BMP-targeted genes $I d 1$ and $I d 3$, and a significant elevation of the pluripotency-related genes Oct4 and Nanog (Fig. 3C). Western blotting with equal amount of concentrates of conditioned medium collected from wild-type and mutant EB cultures confirmed that Noggin was indeed expressed at higher levels in Pelo-null than in wild-type EB culture (Fig. 3D). These results indicate that increased levels of Noggin in conditioned medium derived from Pelo-deficient EB culture are responsible for the impaired ExEn development in wild-type EBs.

To confirm whether the decreased activity of BMP signaling in Pelo-deficient cells is responsible for the impaired ExEn development, mutant Pelo ${ }^{1-}$ ESCs were aggregated and cultured in serum replacement medium (SR medium) supplemented with recombinant BMP4. Expression analysis showed that the expression of BMP-target genes Id 1 and Id3, and ExEn markers was significantly induced in BMP4-treated mutant EBs compared to that of BMP4untreated EBs (Fig. 3E). The ExEn formation as judged by immunostaining further confirmed that the attenuated activity of BMP signaling is indeed responsible for impaired development of ExEn in Pelo-deficient EBs (Fig. 3F). A significant decrease in the expression levels of Oct4 and Nanogwas observed in mutant EBs grown in culture medium supplemented with BMP4 (Fig. 3E). These results suggest that the persistent expression of pluripotency genes in mutant EBs is not primarily due to PELO deficiency, but rather to failed development of ExEn in these EBs. Further experiments were performed to confirm previously reported results (Conley et al., 2007), which showed that the ExEn formation is disrupted in wild-type EBs grown in medium supplemented with Noggin (Figs. 3G, H).

To further verify the attenuated activity of BMP signaling in Pelo-null cells, we have established a BMP responsive reporter cell line $\left(\right.$ Pelo ${ }^{F /-}$ BRE-FFLuc) by stably integrating BMP responsive dual luciferase reporter construct pBFIR (Yadav et al., 2012). ThePelo ${ }^{\mathrm{F} /}$ - BRE-FFLuccell lines were treated with 4-OHT to generate mutantPelo ${ }^{1-}$ BRE-FFLucESCs. After growing EBs from both Pelo ${ }^{F /-}$ BRE-FFLuc and Pelo ${ }^{-1}$ $B R E$-FFLuccell lines in SR medium, they were further cultured in medium supplemented either with or without BMP4. As shown inFig. 3I, the relative FFLuc activities were increased significantly in BMP4-treated Pelo F/- BRE-FFLuc and Pelo /$B R E-F F L u c E B s$. However, the relative FFLuc activity in control cells was significantly higher than that of mutant cells. In order to further examine the presence of BMP antagonists in the conditioned medium of Pelo ${ }^{\prime-} \mathrm{EBs}$, relative FFLuc activities were measured inPelo ${ }^{\mathrm{F} /}-\mathrm{BRE}$-FFLuc EBs that were treated for $12 \mathrm{~h}$ either withPelo ${ }^{1-}$ conditioned medium or with Pelo ${ }^{\prime-}$ conditioned medium and BMP4. We observed that the relative FFLuc activity was significantly reduced in control Pelo ${ }^{F /-}$ BRE-FFLuc EBs treated with Pelo ${ }^{1-}$ conditioned medium compared to untreated control (Fig. 3M). This reduced activity was restored in control Pelo $\mathrm{F}^{\prime-}$ BRE-FFLuc EBs, which were treated with both Pelo ${ }^{1-}$ conditioned medium and BMP4 (Fig. 3M). Collectively, these results further confirm that the mutant Pelo ${ }^{1-}$ EBs produce extracellular modulators of BMP signaling activity. 

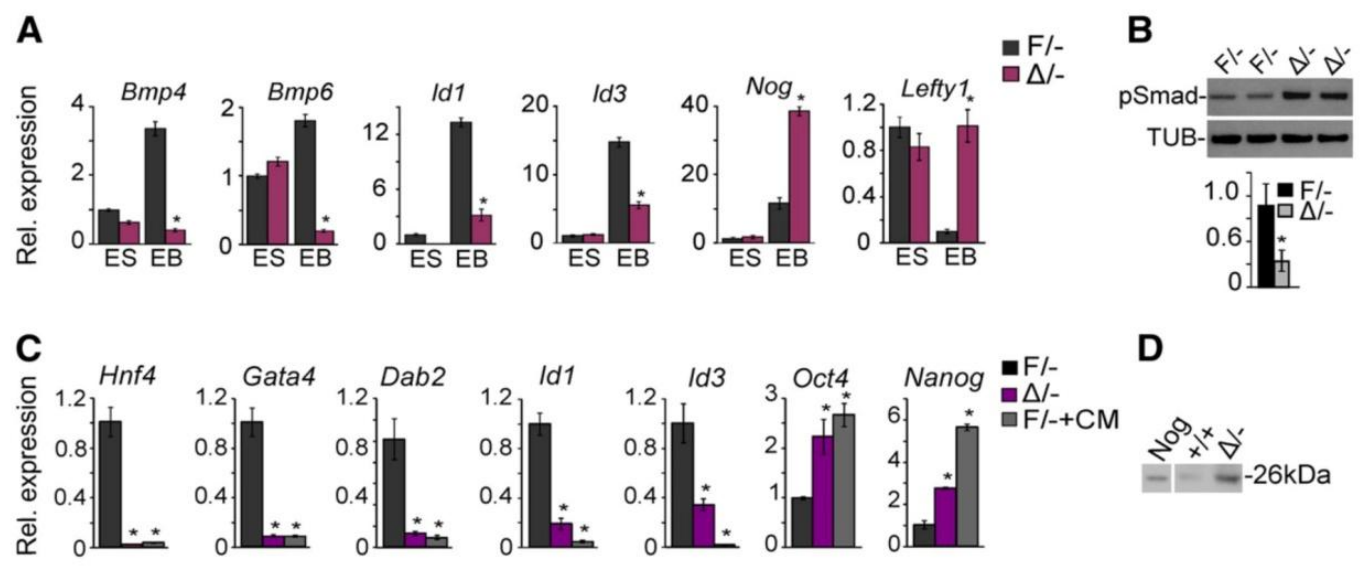

D
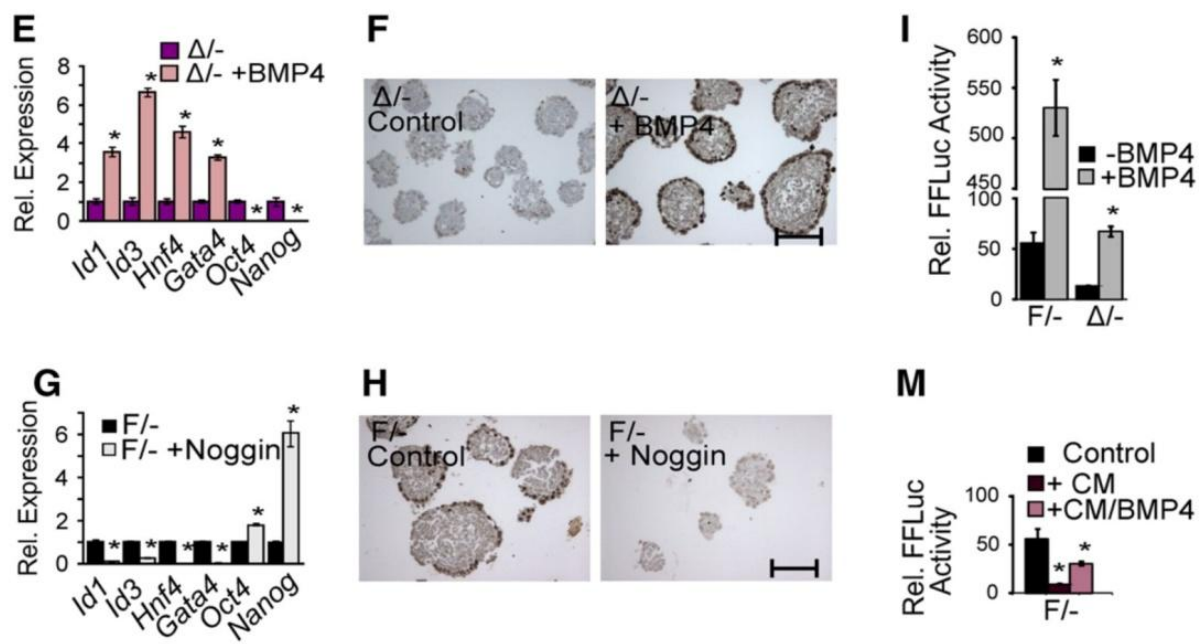

M

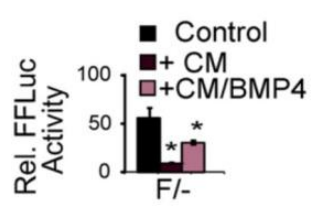

Figure 3 Attenuated activity of BMP signaling in Pelo ${ }^{1-}$ EBs. (A) Quantitative RT-PCR analysis for expression of BMP ligands, BMP-target genes and antagonists (NogginandLefty 1) in controlPelo ${ }^{\mathrm{F} /-}$ and mutantPelo ${ }^{1-} \mathrm{ESC}$ and EBs on day 5 of differentiation. (B) Western blot analysis was performed to determine the expression levels of pSmad1/5 (pSmad) in control and mutant EBs (upper panel). In the bar graph presented in the lower panel, expression levels of pSmad1/5 were normalized to that of $\alpha$-tubulin (TUB). Value is presented as mean \pm SD. (C) Quantitative RT-PCR analysis for expression of ExEn, BMP-target genes and pluripotency markers in control Pelo ${ }^{F /-}$, mutant Pelo ${ }^{1-}$ EBs as well as control Pelo ${ }^{F /-}$ EBs, which were cultured in conditioned medium derived from Pelo-deficient EB cultures (Pelo $\left.{ }^{F /-}+\mathrm{CM}\right)$. Values of expression levels in $\mathrm{A}$ and $\mathrm{C}$ normalized toHprtare presented as mean $\pm \mathrm{SD}$ of three experiments. Transcript levels of control ESCs and EBs in A and C, respectively, were expressed as 1.0. *, significantly different from control ESCs (A) or EBs (C); $<0.05$. (D) Western blotting showingPelo /-'-conditioned medium containing higher levels of Noggin than that in control-conditioned medium. Nog, $100 \mathrm{ng}$ of recombinant Noggin was used as loading control. (E-H) Mutant $\mathrm{PelO}^{\prime-}$ and controlPelo ${ }^{\mathrm{F}-} \mathrm{EBs}$, which were grown for 5 days in SR medium supplemented with either $20 \mathrm{ng} / \mathrm{ml} \mathrm{BMP} 4$ (D, E) or $150 \mathrm{ng} / \mathrm{ml}$ Noggin $(F, H)$, respectively, were subjected for RNA expression $(E, G)$ and immunohistochemical analysis $(F, H)$. $(E, G)$ Quantitative RT-PCR analysis for expression of BMP-target, ExEn and pluripotency markers in BMP4-treatedPelo ${ }^{\prime-}$ (E) and Noggin-treatedPelo ${ }^{F /-} \mathrm{EBs}$ (G). Values of expression levels in $\mathrm{E}$ and $\mathrm{G}$ normalized toHprtare presented as mean \pm SD of three experiments. Transcript levels of BMP4- and Noggin-untreatedPelo ${ }^{1-}$ andPelo ${ }^{F /-}$ in E and G, respectively, were expressed as 1.0. *, significantly different from control BMP4-untreated Pelo ${ }^{\prime-}$ EBs (E) and Noggin-untreatedPelo ${ }^{\prime /-}$ EBs $(\mathrm{G}) ; p<0.05 .(\mathrm{F}, \mathrm{H})$ Paraffin sections of mutantPelo $1-$ and control $\mathrm{Pelo}^{\mathrm{F} /-}$ EBs were immunostained with anti-GATA4 antibody. Paraffin sections and RNAs prepared fromPelo ${ }^{1-}$ andPelo ${ }^{\mathrm{F} /-}$ EBs, which grown only in SR medium, were used as untreated controls. Scale bars in F and $\mathrm{H}: 20 \mu \mathrm{m}$. (I)Pelo ${ }^{\mathrm{F} /-}$ FFLuc andPelo ${ }^{1-}$ FFLuc Luc ESCs were aggregated and grown in SR medium for 5 days and then treated for $12 \mathrm{~h}$ in SR medium supplemented either with or without BMP4. (M)Pelo ${ }^{F /-}$ FFLuc EBs were cultured either with conditioned medium collected from mutantPelo ${ }^{1-}$ EBs or with conditioned medium collected from mutantPelo ${ }^{1-}$ EBs supplemented with BMP4. Relative FFLuc activity (FFLuc/RRLuc) in I and M is presented as mean \pm SD of three experiments. *, significantly different from control cells; $p<0.05$. 


\section{Pelo-depleted fibroblasts fail to generate iPSCs}

To investigate whetherPelois essential for the establishment of induced pluripotency in somatic cells, we performed reprogramming studies with mouse embryonic fibroblasts (MEFs) generated from controls (Nanog-EGFP, Pelo ${ }^{\mathrm{F} /+}$ and Pelo ${ }^{F /-}$ ), and mutant Pelo ${ }^{\Delta /-}$ embryos. Delivery of reprogramming factors, Oct3/4, Sox2, Klf4, and c-Myc (OSKM) into control, Nanog-EGFP, and $\mathrm{Pelo}^{\mathrm{F} /+} \mathrm{MEFs}$ resulted in the appearance of AP-positive iPSC colonies (Figs. 4A, B), which were morphologically indistinguishable from ESC colonies and expressed pluripotency markers (data not shown). Delivery of reprogramming factors into Pelo-heterozygous $\mathrm{PelO}^{\mathrm{F} /-} \mathrm{MEFs}$ revealed a reduced number of AP-positive iPSC colonies (Figs. 4A, B). The established Pelo $\mathrm{F}^{\mathrm{F}-}$ iPSC colonies showed stereotypical colony morphology similar to ESCs and expressed pluripotency markers, such as SSEA1, Oct3/4, Sox2, and Nanog (Suppl. Figs. 7A, B). Interestingly, Pelo ${ }^{\Delta /-}$ MEFs failed to reprogram and showed no AP-positive colonies (Figs. 4A, B). To verify whether overexpression of Pelo can rescue the inability of $\mathrm{PelO}^{\Delta /-}$ to yield iPSCs, we performed reprogramming studies by Pelo supplementation to the OSKM factors (Figs. 4C, D). Notably, the addition of Pelo greatly enhanced the iPSC generation from Nanog-EGFP, $\mathrm{PelO}^{\mathrm{F} /+}$, and Pelo $^{F /-}$ MEFs, compared to OSKM alone (Figs. 4A-D). Moreover, we obtained iPSCs from $\mathrm{PelO}^{\Delta /-}$, confirming the rescue
(Figs. 4C, D). To corroborate that Pelo deficiency does not lead to the loss of pluripotency once it is established, as observed for Pelo ${ }^{\Delta /-}$ ESCs, we treated Pelo ${ }^{F /-}$ iPSCs with 4-OHT. The homozygous deletion of Pelo in iPSCs $\left(\mathrm{PelO}^{\Delta /-}\right)$ revealed smaller colony morphology and slower growth, as observed for Pelo ${ }^{\Delta /-}$ ESCs, but were positive for AP-staining and pluripotency genes (Suppl. Fig. S7C and data not shown).

\section{BMP and MET are misregulated during the reprogramming ofPelo-deficient fibroblasts}

During the early phase of iPSC induction, an increase of BMP activity is necessary to promote mesenchymal-to-epithelial transition (MET) (Li et al., 2010; Samavarchi-Tehrani et al., 2010). Hence, we comparatively analyzed the expression of Bmp6andNogginbetween days 6 and 9 of reprogramming of $\mathrm{PelO}^{\mathrm{F} /+}$ andPelo ${ }^{\Delta /-}$ MEFs (Fig. 5A). TheBmp6expression was not upregulated inPelo ${ }^{\Delta /-}$ cells at day 6 of reprogramming, but was highly up-regulated in Pelo ${ }^{F /+}$ MEFs (Fig. 5A). In agreement with these results, Noggin was dramatically down-regulated in control cells by day 6 of reprogramming (Fig. 5A). The slight change in expression levels of Bmp6 and Noggin in Pelo ${ }^{\Delta /-}$ cells persisted through day 9 of reprogramming (Fig. 5A). Simultaneously, we also analyzed the expression levels of both mesenchymal and epithelial
A

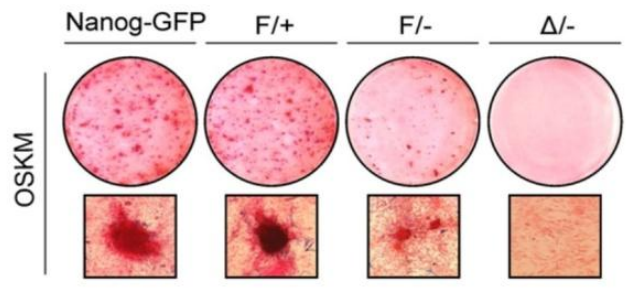

C

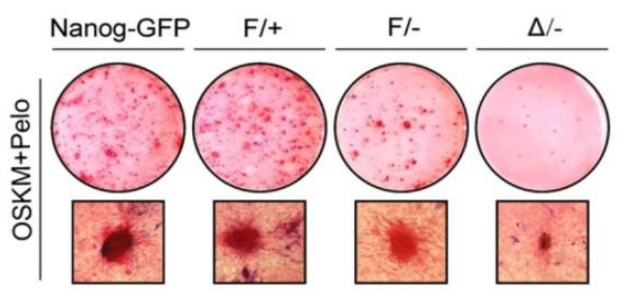

B
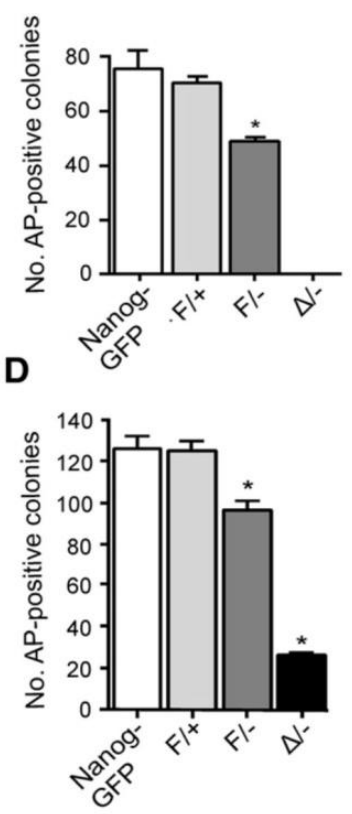

Figure 4 Pelois required for somatic cell reprogramming. (A) Representative images of AP staining of various MEFs undergoing reprogramming with classical reprogramming factors (OSKM) (upper panel). High magnification of single colonies is shown in the lower panel. (B) The number of AP-positive colonies in reprogramming plates was counted 14 days post-transduction with OSKM vectors. Data are shown as the mean \pm SD of three experiments. *, significantly different from control Nanog-GFP cells; $p<0.05$. (C) Representative images of AP staining of various MEFs undergoing reprogramming with classical reprogramming factors (OSKM) together withPelo(upper panel). High magnification of single colonies is shown in the lower panel. (D) The number of AP-positive colonies in reprogramming plates shown in D was counted 14 days post-transduction with OSKM together withPelo. Data are shown as the mean \pm SD of three experiments. ${ }^{*}$, significantly different from control Nanog-GFP cells; $p<0.05$. 
A
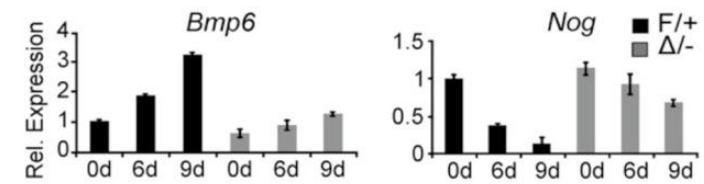

B
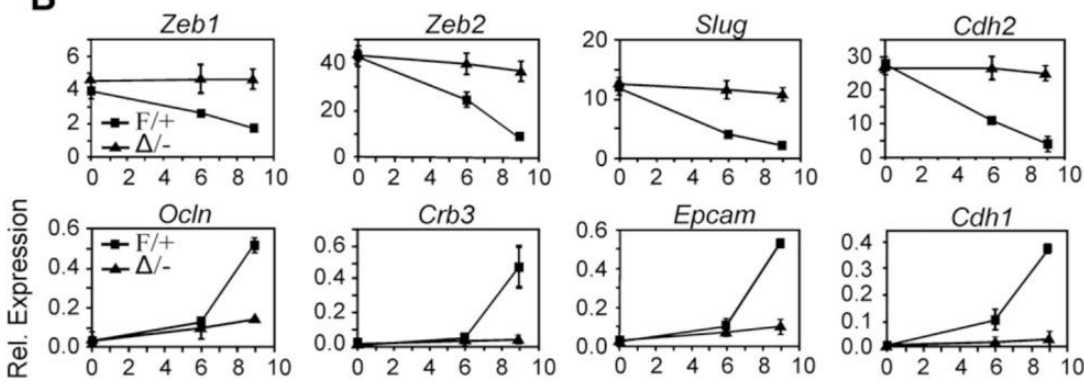

Crb3
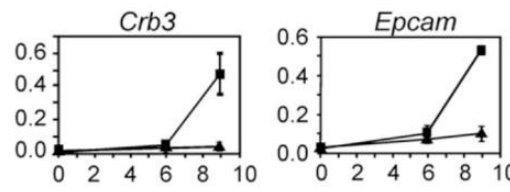

Cdh1
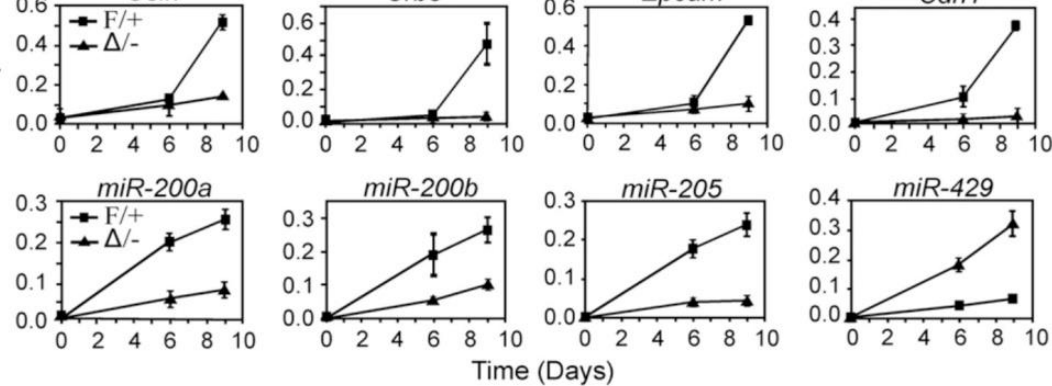

Figure 5 Expression of BMP signaling and MET components during the reprogramming ofPelo-deficient MEFs. (A) Expression of Bmp6andNoggin $(\mathrm{Nog})$ in controlPelo $\mathrm{F}^{\prime+}$ and mutantPelo ${ }^{1-} \mathrm{MEFs}$ on days 0,6 and 9 of reprogramming. Transcript levels inPelo $\mathrm{F} /-$ MEFs on day 0 are shown as 1.0. (B) Line graphs showing the expression levels of mesenchymal and epithelial marker genes as well as miRNAs on days 0,6 , and 9 of reprogramming.

marker genes and miRNAs, which promote the MET, during the reprogramming of $\mathrm{PelO}^{\Delta /-} \mathrm{MEFs}$ compared to control MEFs (Fig. 5B). The expression of mesenchymal marker genes (Zeb1, Zeb2, Slug, and Cdh2) was significantly down-regulated in $\mathrm{PelO}^{\mathrm{F} /+}$, but their expression was unchanged or slightly reduced in Pelo ${ }^{\Delta /-}$ MEFs even after 9 days of reprogramming (Fig. 5B). In line with these results, epithelial marker genes (Ocln,Crb3,EpcamandCdh1) were highly up-regulated in reprogrammed control cells but not in Pelo ${ }^{\Delta /-}$ cells (Fig. 5B). The expression of miRNAs (miR-200a, $-200 \mathrm{~b},-205$, and -429 ), which promote the MET process, was highly upregulated inPelo ${ }^{\mathrm{F} /+}$ cells, but not inPelo ${ }^{\Delta /-}$ cells (Fig. 5B).

\section{Conserved function of mammalian PELO in NGD}

To determine whether the role of PELO in NGD is also conserved in mammalian cells, we analyzed control and Pelo-deficient ESCs for expression of the EGFP reporter gene (SL-EGFP) containing a stable stem loop (SL) located in frame with EGFP (Fig. 6A). Northern blot analysis revealed that EGFP-Zeo-fusion RNA was stable in mutant ESCs compared with control ESCs (Fig. 6B), whereas no EGFP-fluorescence and -protein were seen in either control or mutant ESCs (Fig. 6C and data not shown). These results suggest that ribosome stalled at stem-loop structure affects the translation of reporter mRNA in both mutant and wild-type ESCs and that the presence of PELO in wild-type ESCs might trigger the decay of EGFP mRNAs containing the stalled ribosomes. In contrast,
thePelo-deficient cells might be inefficient in activating the NGD, thereby accumulating the reporter mRNAs.

Significant increase in expression levels of Noggin in mutant EBs led us to examine the consequences of PELO depletion on the mRNA stability of Noggin. We performed actinomycin $D$ chase experiments to monitor the posttranscriptional changes in levels ofNoggin mRNA in Pelo ${ }^{\mathrm{F} /}$ andPelo ${ }^{\prime-}$ cells. The mRNA levels of Nogginwere gradually decreased after actinomycin $D$ treatment with a similar time course in control and Pelo-null cells (Fig. 6D), indicating that the turnover of Noggin mRNA is not controlled by PELO-dependent mRNA decay.

\section{Discussion}

We previously reported that the conventional genetic depletion of Peloin mouse results in an embryonic lethality at early post-implantation stages (Adham et al., 2003). Here, we report that Pelo-null ESCs are continuously propagated and retained their capacity to form undifferentiated colonies at clonal densities, but fail to differentiate into ExEn lineage in EBs. Conversely, overexpression of Pelo in ESCs led to down-regulation of pluripotency-related genes and a preferential activation of genes that regulate the differentiation of ESCs into an ExEn cell lineage.

Upon the aggregation of ES cells in suspension, the outer layer of developing EBs differentiates into ExEn, which deposits extracellular matrix into the underlying basement membrane (BM). Inside the BM, a primitive ectoderm layer is 
A

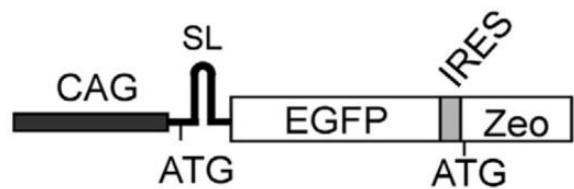

B

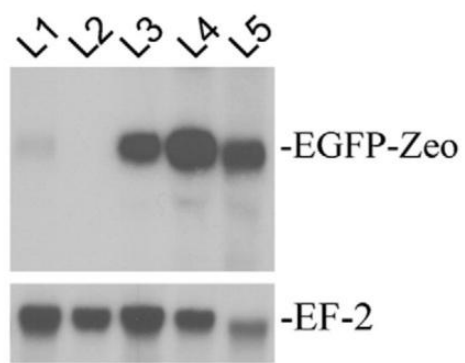

D

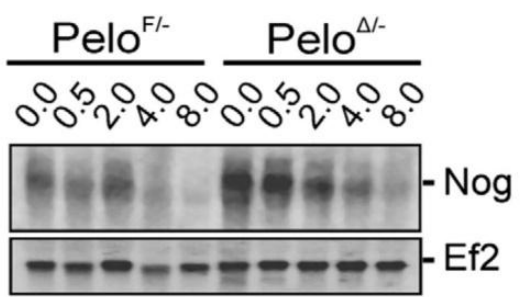

C
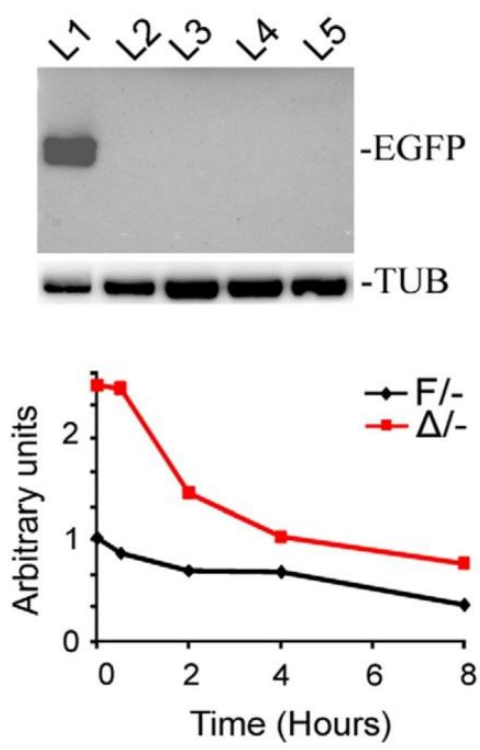

Figure 6 Conserved function of mammalian PELO in NGD. (A) Schematic diagram of the pCAG-SL-EGFP-ZEO construct. The stem loop (SL) sequence is located at the same reading frame with EGFP reporter gene. The internal ribosome entry site (IRES) is inserted between EGFP and zeocin (Zeo) resistant gene. (B) Blot containing RNA from SL-EGFP-overexpressing controlPelo ${ }^{\text {/ }}$ (L1), mutant $^{-}$ Pelo $^{1-}$ ES clones (L3-L5) and untransfected ESCS (L2) was hybridized with an EGFP probe. (C) Blot with protein extracts from SL-EGFP-overexpressingPelo ${ }^{\mathrm{F}-}$ (L2, L3) andPelo ${ }^{\prime-}$ ES clones (L4, L5) andVsig-EGFPtransgenic stomach as a control (L1) was probed with anti-GFP antibody. The membrane was subsequently reprobed with $\alpha$-tubulin antibody. (D)NogginmRNA stability in control $\mathrm{PelO}^{\mathrm{F} /-}$ and mutantPelo ${ }^{--}$EBs. Control andPelo-deficient EBs were treated with actinomycin D, and total RNA was isolated after 0, $0.5,2,4$ and 8 h of treatments. RNA blots were hybridized withNoggincDNA probe. Expression levels of Nanogwere normalized to correspondingEF-2mRNA levels. The normalized levels in control cells at time 0 were expressed as 1.00 , and all other normalized mRNA levels were graphed relative to that value (left panel).

developed, and cavitation is formed in the core of the EBs (Niwa, 2010). The developmental process of EBs mimics the early embryonic stages of late blastocyst to egg cylinder (E4.5-E6.5). Both formation of ExEn and cavitation have been shown to be regulated by the BMP signaling pathway in mouse embryos and EBs. Thus, inhibition of BMP signaling by expression of a dominant-negative BMP receptor, down-regulation ofBmp6expression in ectodermal cells or addition of the BMP antagonist Noggin in culture prevents the development of ExEn in EBs (Coucouvanis and Martin, 1999; Conley et al., 2007; Rong et al., 2012). A significant decrease in the expression levels of BMP-targeted genes, phosphorylated Smad1/5, and the overexpression of Noggin inPelo-deficient EBs suggest that PELO regulates differentiation toward ExEn lineage through the activation of BMP signaling. These results were supported by the observations of restored ExEn development in mutant EBs grown in medium supplemented with BMP4. Further, the negative effect of conditioned medium collected from mutant EBs on the ExEn formation in wild-type EBs and the significant decrease of luciferase activity in the BMP responsive reporter cell line indicate that mutant EBs secrete extracellular modulators which attenuate the BMP signaling activity.

Several factors regulate the activity of BMP signaling at intracellular and extracellular levels. The responsiveness of wild-type and mutant cells to Noggin and BMP4 treatment excludes the role of PELO in regulation of the intracellular modulators of BMP signaling. Extracellular modulators such as Noggin and Chordin antagonize the BMP signal (Piccolo et al., 1996; Zimmerman et al., 1996). Acute overexpression of NoggininPelo-null EBs led to suggest that PELO regulates the BMP signaling by negatively regulatingNogginexpression at either transcriptional or post-transcriptional levels. Cytoplasmic localization of PELO in human and Drosophila cells (Xi et al., 2005; Burnicka-Turek et al., 2010) rules out that PELO directly regulates Noggin at the transcriptional level. In addition, the fact that the conserved role of PELO in NGD and deletion of PELO do not affect the stability of 
Noggin transcripts suggests that PELO indirectly downregulates Noggin through controlling stability of transcription factors regulating Noggin expression. Taken together, these results led us to conclude that the reduced BMP signaling inPelo-null EBs accounts for the observed defect in ExEn differentiation. In support of our results, impaired ExEn development as a result of the affected BMP signaling was also shown in Smad4-deficient EBs (Sirard et al., 1998).

Moreover, BMP-mediated MET activation was shown to be essential for the induction of pluripotency in somatic cells (Li et al., 2010; Samavarchi-Tehrani et al., 2010). The failure of Pelo-deficient MEFs to activate BMP signaling during reprogramming reinforces that PELO is an indispensable component for the activation of BMP signaling during the establishment of pluripotency and ExEn cell lineage commitment.

The failure ofPelo-null ESCs to undergo ExEn differentiation was accompanied by a significant decrease in the expression levels of the transcription factors Gata4, Gata6 and $H n f 4$, which are involved in differentiation and functions of ExEn lineage. Similarly, ESCs lacking eitherGata4 or Gata6 failed to form the endodermal outer layer (Soudais et al., 1995; Morrisey et al., 1998). Like the overexpression of Gata4 and Gata6(Fujikura et al., 2002), forced expression of Pelo directs differentiation of ExEn lineage in ESCs. Remarkably, the expression levels of the Pelo transcript were approximately 1.7-fold higher than that of wild-type ESCs. However, this modest change was sufficient to induce differentiation of ESCs into cells positive for ExEn markers, suggesting a quantitative effect ofPeloon ESC differentiation.

The recovery of ExEn outer layer and down-regulation of pluripotent genes in mutant EBs grown in medium supplemented with BMP4 indicate that the failure ofPelo-null cells to down-regulate pluripotency-related genes in EBs is not a result of cell-autonomous effect, but rather to failed signals from surrounding ExEn that induce the differentiation program. These findings are in agreement with the results showing that the persistence of pluripotent cells in Dido 3-deficient EBs is a result of the failed ExEn development (Futterer et al., 2012). The differentiation ofPelo-deficient ESCs to different germ layers in teratoma assay and to ExEn in response to retinoic acid confirms that the loss of PELO does not impair the differentiation of ESCs. Further in vivo studies showed the presence of ExEn inPelo-null embryos at E6.5 and embryonic lethality at E7.5. These results led us to suggest that PELO is not required for the induction of ExEn, but rather for the maintenance or terminal differentiation toward functional visceral endoderm. Like Pelo mutants, targeted deletion ofGata6,Dab2andHnf4genes, which are initially expressed in ExEn, resulted in early embryonic lethality. Despite the failed development of ExEn in the Gata6-, Dab2- and Hnf4-deficient EBs, ExEn is formed in their mutant E6.5 embryos (Duncan etal., 1997; Morrisey et al., 1998; Yang et al., 2002). These studies have attributed the affected development of mutant embryos to deficiency of functional ExEn. Restoration of ExEn development in Pelo-null EBs by supplementation of RA led us to suggest that RA-regulated pathway might have induced the ExEn differentiation inPelo-null embryo at E6.5.

Our experiments showed that PELO deficiency inhibits the reprogramming of somatic cells, whereas the overexpression of Pelo along with other reprogramming factors promotes efficient reprogramming. These results suggest that PELO is required during the initiation stage of reprogramming, and its loss impairs the process. Recent reports revealed that increased BMP signaling during the initial stages of reprogramming promotes the MET (Li et al., 2010; Samavarchi-Tehrani et al., 2010). The failure of BMP signaling activation inPelo /- cells undergoing reprogramming suggests a critical role of PELO in the early phase of somatic reprogramming, probably by activating BMP signaling. Consistent with the absence of reprogramming inPelo ${ }^{1-}$ cells, the expression levels of mesenchymal and epithelial markers in Pelo ${ }^{\prime-}$ reprogrammed cells were not significantly altered compared to those in parentalPelo ${ }^{1-}$ MEF cells.

Collectively, our results highlight the role of PELO in the activation of BMP signaling in order to drive the establishment of pluripotency and ExEn lineage. Further studies aimed at the identification and characterization of protein complexes containing PELO and how PELO activates BMP signaling will shed light on the function of PELO in these processes.

\section{Acknowledgments}

This work was supported in part by DFG grant Ad 129/2 to I.M.A. and by University Medical Center of Göttingen (Forschungsförderungsprogramm) to I.M.A. We are grateful to L.K. Dörfel (Institute of Human Genetic, Göttingen) for kindly helping us in characterization and analyses of Pelo-deficient ESCs and mice. We thank J. Nolte (Institute of Human Genetic, Göttingen) for her help in protein analysis; $M$. Schindler and U. Fünfschilling (MPI for Experimental Medicine, Göttingen) for their help in the generation of knockout mice; A. Nagy (Mount Sinai Hospital, Toronto) for providing RI ES cells; M. Conrad (Institute of Clinical Molecular Biology and Tumor Genetics, GSF, Munich) for providing PPNT4; A. Berns and A. Loonstra (The Netherlands Cancer Institute, Amsterdam) for providing Rosa 26 Cre ERT2 mice; and H. Niwa (Riken Center, Kobe, Japan) and A. Bandyopadhyay (Indian Institute of Technology, Kanpur, India) for providing CAG-IRES-ZEO and pBFIR vector, respectively.

\section{Appendix A. Supplementary data}

Supplementary data to this article can be found online at http://dx.doi.org/10.1016/j.scr.2014.04.011.

\section{References}

Adham, I.M., Sallam, M.A., Steding, G., Korabiowska, M., Brinck, U., Hoyer-Fender, S., Oh, C., Engel, W., 2003. Disruption of the pelota gene causes early embryonic lethality and defects in cell cycle progression. Mol. Cell. Biol. 23, 1470-1476.

Bielinska, M., Narita, N., Wilson, D.B., 1999. Distinct roles for visceral endoderm during embryonic mouse development. Int. J Dev. Biol. 43, 183-205.

Burnicka-Turek, O., Kata, A., Buyandelger, B., Ebermann, L., Kramann, N., Burfeind, P., Hoyer-Fender, S., Engel, W., Adham, I.M., 2010. Pelota interacts with HAX1, EIF3G and SRPX and the resulting protein complexes are associated with the actin cytoskeleton. BMC Cell Biol. 11, 28.

Cai, K.Q., Caslini, C., Capo-chichi, C.D., Slater, C., Smith, E.R., Wu, H., Klein-Szanto, A.J., Godwin, A.K., Xu, X.X., 2009. Loss of GATA4 
and GATA6 expression specifies ovarian cancer histological subtypes and precedes neoplastic transformation of ovarian surface epithelia. PLoS One 4, e6454.

Capo-Chichi, C.D., Rula, M.E., Smedberg, J.L., Vanderveer, L., Parmacek, M.S., Morrisey, E.E., Godwin, A.K., Xu, X.X., 2005. Perception of differentiation cues by GATA factors in primitive endoderm lineage determination of mouse embryonic stem cells. Dev. Biol. 286, 574-586.

Carr-Schmid, A., Pfund, C., Craig, E.A., Kinzy, T.G., 2002. Novel $\mathrm{G}$-protein complex whose requirement is linked to the translational status of the cell. Mol. Cell. Biol. 22, 2564-2574.

Chazaud, C., Yamanaka, Y., Pawson, T., Rossant, J., 2006. Early lineage segregation between epiblast and primitive endoderm in mouse blastocysts through the Grb2-MAPK pathway. Dev. Cell 10, 615-624

Chen, L., Muhlrad, D., Hauryliuk, V., Cheng, Z., Lim, M.K., Shyp, V., Parker, R., Song, H., 2010. Structure of the Dom34-Hbs1 complex and implications for no-go decay. Nat. Struct. Mol. Biol. 17, 1233-1240.

Cockburn, K., Rossant, J., 2010. Making the blastocyst: lessons from the mouse. J. Clin. Invest. 120, 995-1003.

Conley, B.J., Ellis, S., Gulluyan, L., Mollard, R., 2007.BMPs regulate differentiation of a putative visceral endoderm layer within human embryonic stem-cell-derived embryoid bodies. Biochem. Cell Biol. 85, 121-132.

Coucouvanis, E., Martin, G.R., 1999.BMP signaling plays a role in visceral endoderm differentiation and cavitation in the early mouse embryo. Development 126, 535-546.

Doetschman, T.C., Eistetter, H., Katz, M., Schmidt, W., Kemler, R., 1985. The in vitro development of blastocyst-derived embryonic stem cell lines: formation of visceral yolk sac, blood islands and myocardium. J. Embryol. Exp. Morphol. 87, 27-45.

Doma, M.K., Parker, R., 2006. Endonucleolytic cleavage of eukaryotic mRNAs with stalls in translation elongation. Nature 440, 561-564.

Duncan, S.A., Nagy, A., Chan, W., 1997 Murine gastrulation requires HNF-4 regulated gene expression in the visceral endoderm: tetraploid rescue of $\mathrm{Hnf}-4$ ( / ) embryos. Development 124 279-287.

Fujikura, J., Yamato, E., Yonemura, S., Hosoda, K., Masui, S., Nakao, K., Miyazaki Ji, J., Niwa, H., 2002. Differentiation of embryonic stem cells is induced by GATA factors. Genes Dev. 16, 784-789.

Futterer, A., Raya, A., Llorente, M., Izpisua-Belmonte, J.C., de la Pompa, J.L., Klatt, P., Martinez, A.C., 2012.Ablation of Dido3 compromises lineage commitment of stem cells in vitro and during early embryonic development. Cell Death Differ. 19, 132-143.

Graille, M., Chaillet, M., van Tilbeurgh, H., 2008. Structure of yeast Dom34: a protein related to translation termination factor Erf1 and involved in No-Go decay. J. Biol. Chem. 283, 7145-7154.

Hameyer, D., Loonstra, A., Eshkind, L., Schmitt, S., Antunes, C., Groen, A., Bindels, E., Jonkers, J., Krimpenfort, P., Meuwissen, R., et al., 2007.Toxicity of ligand-dependent Cre recombinases and generation of a conditional Cre deleter mouse allowing mosaic recombination in peripheral tissues. Physiol. Genomics 31, 32-41.

Jetten, A.M., Jetten, M.E., Sherman, M.I., 1979. Stimulation of differentiation of several murine embryonal carcinoma cell lines by retinoic acid. Exp. Cell Res. 124, 381-391.

Koutsourakis, M., Langeveld, A., Patient, R., Beddington, R., Grosveld, F., 1999. The transcription factor GATA6 is essential for early extraembryonic development. Development 126, 723-732.

Lakso, M., Pichel, J.G., Gorman, J.R., Sauer, B., Okamoto, Y., Lee, E., Alt, F.W., Westphal, H., 1996. Efficient in vivo manipulation of mouse genomic sequences at the zygote stage. Proc. Natl. Acad. Sci. U. S. A. 93, 5860-5865.

Li, R., Liang, J., Ni, S., Zhou, T., Qing, X., Li, H., He, W., Chen, J., Li, F., Zhuang, Q., et al., 2010. A mesenchymal-to-epithelial transition initiates and is required for the nuclear reprogramming of mouse fibroblasts. Cell Stem Cell 7, 51-63.

Mitsui, K., Tokuzawa, Y., Itoh, H., Segawa, K., Murakami, M. Takahashi, K., Maruyama, M., Maeda, M., Yamanaka, S., 2003. The homeoprotein Nanog is required for maintenance of pluripotency in mouse epiblast and ES cells. Cell 113, 631-642.

Molkentin, J.D., Lin, Q., Duncan, S.A., Olson, E.N., 1997. Require ment of the transcription factor GATA4 for heart tube formation and ventral morphogenesis. Genes Dev. 11, 1061-1072.

Morrisey, E.E., Tang, Z., Sigrist, K., Lu, M.M., Jiang, F., Ip, H.S., Parmacek, M.S., 1998.GATA6 regulates HNF4 and is required for differentiation of visceral endoderm in the mouse embryo. Genes Dev. 12, 3579-3590.

Niwa, H., 2010. Mouse ES cell culture system as a model of development. Dev. Growth Differ. 52, 275-283.

Okita, K., Ichisaka, T., Yamanaka, S., 2007. Generation of germline competent induced pluripotent stem cells. Nature 448, 313-317.

Piccolo, S., Sasai, Y., Lu, B., De Robertis, E.M., 1996. Dorsoventral patterning in Xenopus: inhibition of ventral signals by direct binding of chordin to BMP-4. Cell 86, 589-598.

Plusa, B., Piliszek, A., Frankenberg, S., Artus, J., Hadjantonakis, A.K. 2008. Distinct sequential cell behaviours direct primitive endoderm formation in the mouse blastocyst. Development 135, 3081-3091.

Rong, L., Liu, J., Qi, Y., Graham, A.M., Parmacek, M.S., Li, S., 2012. GATA-6 promotes cell survival by up-regulating BMP-2 expression during embryonic stem cell differentiation. Mol. Biol. Cell 23 , 3754-3763.

Samavarchi-Tehrani, P., Golipour, A., David, L., Sung, H.K., Beyer, T.A., Datti, A., Woltjen, K., Nagy, A., Wrana, J.L., 2010. Functional genomics reveals a BMP-driven mesenchymal-toepithelial transition in the initiation of somatic cell reprogramming. Cell Stem Cell 7, 64-77.

Shamsadin, R., Adham, I.M., Engel, W., 2002. Mouse pelota gene (Pelo): cDNA cloning, genomic structure, and chromosomal localization. Cytogenet. Genome Res. 97, 95-99.

Sirard, C., de la Pompa, J.L., Elia, A., Itie, A., Mirtsos, C., Cheung, A., Hahn, S., Wakeham, A., Schwartz, L., Kern, S.E., et al. 1998. The tumor suppressor gene Smad4/Dpc4 is required for gastrulation and later for anterior development of the mouse embryo. Genes Dev. 12, 107-119.

Soudais, C., Bielinska, M., Heikinheimo, M., MacArthur, C.A., Narita, N., Saffitz, J.E., Simon, M.C., Leiden, J.M., Wilson, D.B., 1995. Targeted mutagenesis of the transcription factor GATA-4 gene in mouse embryonic stem cells disrupts visceral endoderm differentiation in vitro. Development 121, 3877-3888.

Takahashi, K., Yamanaka,S., 2006. Induction of pluripotent stem cells from mouse embryonic and adult fibroblast cultures by defined factors. Cell 126, 663-676.

Tam, P.P., Loebel, D.A., 2007. Gene function in mouse embryogenesis: get set for gastrulation. Nat. Rev. Genet. 8, 368-381.

Wurst, W., Joyner, A.L., 1993. Production of targeted embryonic stem cell clones, In: Joyner, A.L. (Ed.), Gene Targeting: A Practical Approach, 1st ed. IRL Press, Oxford, pp. 33-62.

Xi, R., Doan, C., Liu, D., Xie, T., 2005. Pelota controls self-renewal of germline stem cells by repressing a Bam-independent differentiation pathway. Development 132, 5365-5374.

Xu, X., Pantakani, D.V., Luhrig, S., Tan, X., Khromov, T., Nolte, J., Dressel, R., Zechner, U., Engel, W., 2011.Stage-specific germcell marker genes are expressed in all mouse pluripotent cell types and emerge early during induced pluripotency. PLoS One 6, e22413.

Yadav, P.S.,Prashar, P., Bandyopadhyay, A., 2012.BRITER: a BMP responsive osteoblast reporter cell line. PLoS One 7, e37134.

Yamamoto, M., Saijoh, Y., Perea-Gomez, A., Shawlot, W., Behringer R.R., Ang, S.L., Hamada, H., Meno, C., 2004. Nodal antagonists regulate formation of the anteroposterior axis of the mouse embryo. Nature 428, 387-392. 


\section{DISCUSSION}

\subsection{Pelo is indispensable for the maintenance of SSCs}

In this study, we have determined the consequences of Pelo deletion on male germ cells of mice by temporal deletion of Pelo at various stages of development. Histological analysis of testes isolated after different time points of Pelo deletion in adult mice revealed that all germ cells are lost after 45 days of Pelo deletion. Fertility assessment of animals after 15 days of Pelo deletion showed that all spermatozoa in testes of the se mice lack Pelo as determined by transmission of deleted allele to all offspring. These results indicate that Pelo-deficient spermatozoa were able to fertilize the oocytes and the PELO depletion did not impair the progression of meiotic and post-meiotic cells to functional sperm.

Verification of germ cell development after various time points of Pelo deletion by immunohistological analysis revealed that there were no new spermatogenic waves emerging after Pelo deficiency. However, germ cells that entered spermatogenic cycle were capable of completing spermatogenesis. Further immunohistochemical analysis using antibod ies against spermatogonial markers SALL4 and GCNA1 showed depletion of SSCs and the loss of all undifferentiated spermatogonia. The absence of a new wave of differentiated spermatogonia in $83 \%$ of STs of mutant testes by 15 days post injection (DPI) as well as the retention of comparable numbers of SALL4-positive cells in both genotypes up to 15 DPI suggests that Pelo deficiency affects only the early developmental stages of spermatogonia, but does not disrupt the subsequent stages of germ cell development. Moreover, reduced number of $\mathrm{GCNA1}^{+}$cells in spite of the presence of SALL4 ${ }^{+}$cells at 15 DPI suggests that the Pelodeficient SALL4 ${ }^{+}$cells could not further differentiate and continue spermatogenesis. Interestingly, expression analysis of the gene marker for differentiating spermatogonia (Ngn3) after 2 and 5 days of Pelo deletion suggested that arrested spermatogenesis in Pelo depleted testes was due to failed differentiation of spermatogonia. These results suggest that SSC are sensitive to Pelo deletion in adult male mice. The effect of Pelo deletion on SSCs intrigued us to examine the fate of gonocytes, which are the precursor of SSC during the postnatal development. Our observation revealed that the deletion of Pelo during prenatal development did not significantly affect the gonocytes or Sertoli cells. 
There are several genes that are involved in the maintenance of spermatogenesis and regulate the balance between self-renewal and differentiation of SSCs (Table 4.1). The dramatic disruption of spermatogenesis in Pelo-deficient mice is similar to that observed in mice lacking the Plzf, Etv5, Foxol and Shp2 genes, which regulate the self-renewal and differentiation of SSCs (Costoya et al., 2004; Simon et al., 2007; Goertz et al., 2011; Puri et al., 2014). Similar to the Pelo mutant mice, loss of germ cells leading to a Sertoli-cell-only phenotype is also seen in Plzf mutants (Costoya et al., 2004). The inactivation of Plzf results in age-dependent germ cell loss. Analysis of $P l z f^{-1}$ mice showed progressive loss of SSC in most of the tubules and failure of germ cells isolated from $P l z f^{/-}$mice to colonize in host testes confirmed that loss of Plzf leads to depletion of the germline stem cells in testis.

Similarly, SHP2 is essential to complete the initial step of spermatogenesis and production of spermatogonia from SSCs. In the absence of SHP2, undifferentiated spermatogonia are not present, but germ cells beyond this stage of development are capable of completing the process of spermatogenesis. Similar to the Pelo mutants, the gonocytes were not affected by deletion of Shp2. Moreover, apoptosis was not the reason for the loss of germ cells in Shp2deleted mice (Puri et al., 2014). These findings are similar to that found in Pelo mutants where apoptosis was not the cause for germ cell depletion. Another important gene, ETV5 has a specific role in the maintenance of the stem-cell pool and self-renewal of SSCs. Mice with a targeted deletion of Etv $5\left(E t v 5^{-/}\right)$undergo the first wave of spermatogenesis but later the germ cells were lost due to differentiation resulting in a Sertoli-cell-only phenotype in adult $E t v 5^{-1-}$ testes (Chen et al., 2005; Morrow et al., 2007). These observations suggests that Pelo could be one of the important genes involved in the regulation of SSCs self-renewal and maintenance and so indispensable for the male fertility in mouse. 
Table 4.1. Genes that are involved in the regulation of SSCs

\begin{tabular}{|c|c|c|c|c|}
\hline $\begin{array}{l}\text { Gene } \\
\text { Name }\end{array}$ & $\begin{array}{l}\text { Protein } \\
\text { type/Signaling }\end{array}$ & Localization & Phenotype of mutants & Reference \\
\hline Etv5 & $\begin{array}{l}\text { Transcription } \\
\text { factor }\end{array}$ & Spermatogonia & $\begin{array}{l}\text { Effect self-renewal of } \\
\text { spermatogonia and loss of } \\
\text { germ cells }\end{array}$ & $\begin{array}{l}\text { Schlesser et al., } \\
2008\end{array}$ \\
\hline Foxo1 & $\begin{array}{l}\text { Transcription } \\
\text { factor }\end{array}$ & $\begin{array}{l}\text { Gonocytes } \\
\text { spermatogonia }\end{array}$ & $\begin{array}{l}\text { Loss of spermatogonia and } \\
\text { Sertoli cells only phenotyp }\end{array}$ & Goertz et al., 2011 \\
\hline Gilz & $\begin{array}{l}\text { glucoc orticoid- } \\
\text { induced protein }\end{array}$ & Spermatogonia & $\begin{array}{l}\text { Impaired differentiation of } \\
\text { SSC }\end{array}$ & Ngo et al., 2013 \\
\hline Id4 & $\begin{array}{l}\text { Inhibitor } \\
\text { differentiation }\end{array}$ & $\begin{array}{l}\text { Subset of As } \\
\text { spermatogonia }\end{array}$ & $\begin{array}{l}\text { Important for maintaining } \\
\text { SSC pool }\end{array}$ & Chan et al., 2014 \\
\hline$P l z f$ & $\begin{array}{l}\text { Promye locytic } \\
\text { leuke mia zinc- } \\
\text { finger }\end{array}$ & $\begin{array}{l}\text { Gonocytes, } \\
\text { spermatogonia }\end{array}$ & $\begin{array}{l}\text { Progressive loss of } \\
\text { spermatogonia }\end{array}$ & $\begin{array}{l}\text { Costoya et al., } \\
2004\end{array}$ \\
\hline Shp 2 & $\begin{array}{l}\text { Prote in tyrosine } \\
\text { phosphatase }\end{array}$ & Germ cells & $\begin{array}{l}\text { Loss of spermatogonia, } \\
\text { impaired self-renewal }\end{array}$ & Puri et al., 2014 \\
\hline $\operatorname{Sin} 3 a$ & nuc lear corepressı & Sertoli cells & $\begin{array}{l}\text { Loss of undifferentiated } \\
\text { spermatogonia }\end{array}$ & Payne et al., 2010 \\
\hline GDNF & Growth factor & Sertoli cells & $\begin{array}{l}\text { Loss of germ cells due to } \\
\text { failed self-renewal }\end{array}$ & Meng et al., 2000 \\
\hline $\begin{array}{l}\text { Ret/ } \\
\text { GFR } \alpha 1\end{array}$ & $\begin{array}{l}\text { Receptor tyrosine } \\
\text { kinase }\end{array}$ & Spermatogonia & $\begin{array}{l}\text { Impaired germ cell } \\
\text { maturation, Germ cell } \\
\text { depletion, failed self- } \\
\text { renewal }\end{array}$ & $\begin{array}{l}\text { Naughton et al., } \\
2006\end{array}$ \\
\hline Dazl & $\begin{array}{l}\text { Deleted in } \\
\text { azoospermia like }\end{array}$ & Germ cells & $\begin{array}{l}\text { Failure of } A_{\text {al }} \text { to } A 1 \\
\text { transition }\end{array}$ & $\begin{array}{l}\text { Schrans-Stassen } \\
\text { et al., } 2001\end{array}$ \\
\hline
\end{tabular}




\subsection{Regulation of cell cycle in Pelo deleted germ cells}

It was previously found that Pelo is involved in the cell cycle regulation. In Drosophila, Pelo mutants exhibited spermatogenic arrest at $\mathrm{G} 2 / \mathrm{M}$ phase of the first meiotic division. In spermatocytes of Pelo mutants, some processes were observed to be disrupted, such as spindle formation and nuclear envelope breakdown (Castrillon et al., 1993). Nonetheless, germ cell development continued and resulted in $4 \mathrm{~N}$ spermatids possessing head and tail structures. This indicates that PELO does not influence spermiogenesis, but is required for $\mathrm{G} 2 / \mathrm{M}$ transition during meiotic division in Drosophila.

To determine whether the loss of germ cells in Pelo-deficient testes was a result of a defect in cell cycle progression, we analyzed the cell cycle status in control and Pelo-deficient testes. In order to study the cell cycle status of the germ cells, we deleted the gene at postnatal days P8 and P9 by intraperitoneal injection of tamoxifen. The testes were collected at P12, where the meiosis had just started and cells have entered to preleptotene stage. Moreover, at P12 stage the testes were enriched with germ cells at premeiotic stage which enables effective analysis of cell cycle status in germ cells. The collected testes were briefly incubated in medium containing collagenase and testicular cells were re-suspended until a single cell suspension could be prepared. Following washing, the cell suspension was fixed in $70 \%$ ethanol and stained with propidium iodide before subjecting to fluorescent associated cell sorting (FACs).

The FACs analysis revealed a significant increase in the fraction of cells at G2 phase in Pelo mutants than that in the wild type (Fig. 4.1A). This result suggests that the progression of Pelo-deficient germ cells through G1 phase is faster than that in the control. The cell progression from G1 to $\mathrm{S}$ phase is under the control of cyclin D1 (Baldin et al., 1993). Therefore, we investigated the expression pattern of cyclin D1 in control and mutant testes. The protein blot analysis revealed that expression of cyclin D1 in Pelo mutants at 2 and 5 DPI is markedly higher than in controls (Fig. 4.1B). These results suggest that the elevated levels of cyclin D1 result in the increased number of cells in G2 phase. In testes, the regulation of self-renewal and differentiation of SSC is a tightly regulated process (Meng et al., 2000). It is also reported that testis degeneration can be induced by an increase in spermatogonial proliferation, which leads to aberrant entry of the cells into meiosis and subsequent activation of meiotic checkpoints (Handel et al., 1999). 
A

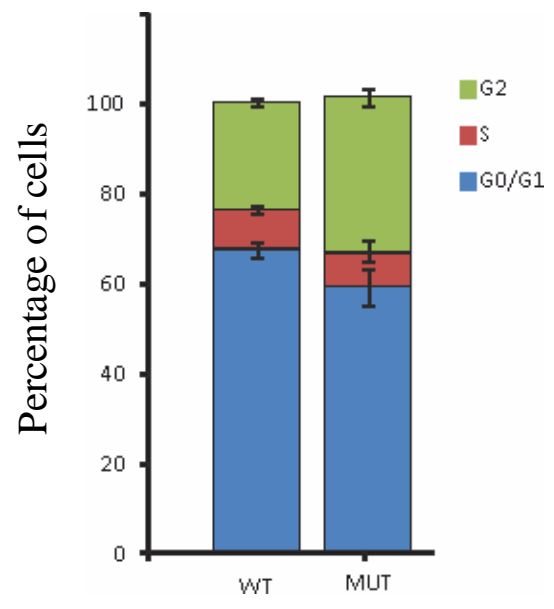

B

Cyclin D1

Tub

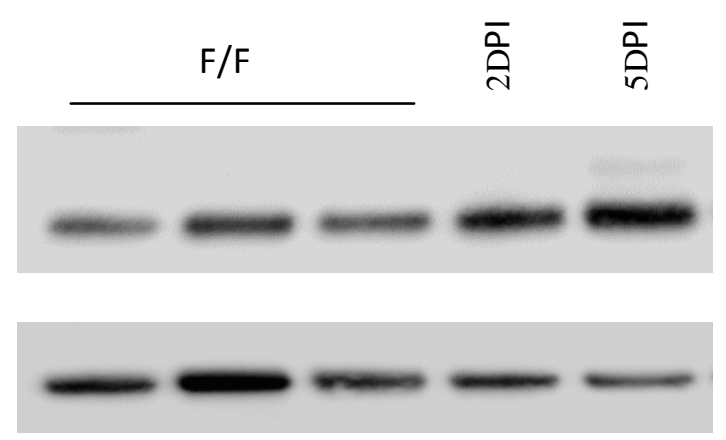

Fig. 4.1. Cell cycle analysis of PELO depleted germ cells. A. Stacked bar graphs showing the percentage of cells at various stages of cell cycle (G0/G1, S and G2) in control (WT) and Pelodeficient testicular cells (Mut). The cell cycle data of three independent experiments were calculated and represented as a mean \pm SD. B. Protein blot analys is performed to determine the expression levels of cyclin D1 in control (F/F) and Pelo mutant at 2 and 5 DPI. The expression $\alpha$-tubulin (Tub) was used as a loading control.

\subsection{Consequences of Pelo over-expression on male germ cells}

Results showing impaired male germ cell development in Pelo-deficient mice led us to determine the consequences of Pelo over-expression on germ cell development. Trans genic mice over-expressing Pelo were available in our institute. The genome of this transgenic mouse contains human Pelo cDNA under the control of the human elongations factor- $1 \alpha$ (HEF-1 $\alpha$ ) promoter (Fig. 4.2A). To investigate the effect of Pelo over-expression on the development of germ cells and its influence on the transition of gonocytes to SSCs, testes from the mutant transgenic mice and control $\mathrm{Pelo}^{\mathrm{F} / \mathrm{F}}$ were isolated at postnatal day 7 , fixed, embedded in paraffin, and histological sections were subjected to immunohistochemical analysis with the anti-GCNA1 antibody (Fig. 4.2B). Most $\mathrm{GCNA}^{+}$cells are localized in the periphery of the seminiferous tubules suggesting a normal development of germ cells at this stage. The mean number of $\mathrm{GCNA}^{+}$cells per seminiferous tubules (Fig. 4.2B) in trans genic testes was not significantly different from that in controls suggesting that the over-expression of PELO did not result in any significant effect on germ cell development. 
A

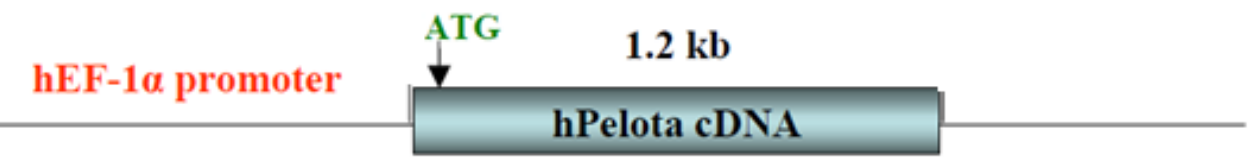

B

$\mathrm{FF}$

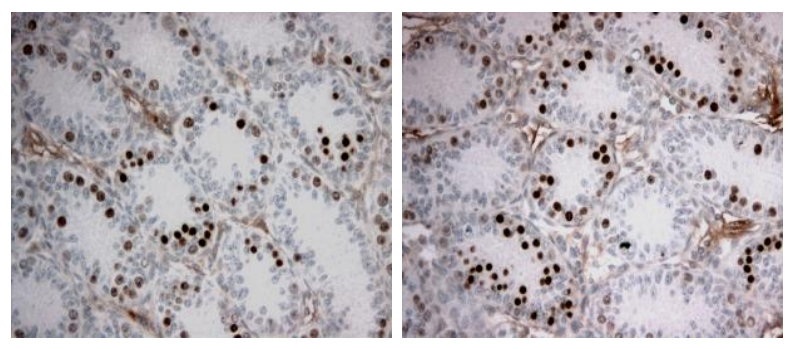

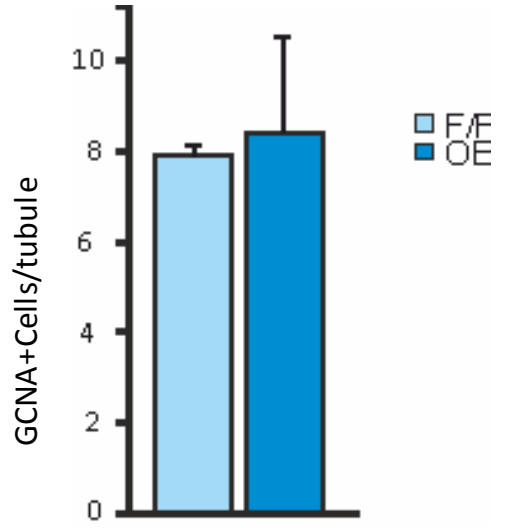

Fig. 4.2. Consequence of Pelo over-expression on male germ cells. A. Schematic diagram of the transgenic construct containing human Pelo cDNA under the control of promotor of human elongation factor-1 $\alpha$. B. Testis sections from control (F/F) and transgenic mice (PELO OE) at P7 were probed with anti-GCNA1 antibody and quantitative analysis of GCNA+ cells per tubule (right panel) in control (F/F) and transgenic testes (OE) of P7 mice. Data represents mean \pm S.D.

\subsection{Pelo deficiency attenuates transcriptional activity of FOXO1 through enhanced activation of PI3K/Akt signaling}

The main functions of SSCs are to maintain undifferentiated SSCs through self-renewal and to generate differentiating daughter spermatogonia that undergo spermatogenesis. Although the molecular mechanisms that regulate the transition of SSCs from self-renewal towards differentiation remain poorly understood, a recent study by Goertz et al. (2011) suggested that FOXO proteins play an important role. FOXO proteins are a family of transcription factors that regulate a wide range of biological processes, from cell proliferation and differentiation, to leukocyte recruitment in inflammation (Jonsson et al., 2005).

Goertz et al. (2011) reported that either deletion or hyper-activation of FOXO1 can lead to spermatogenic failure, suggesting that very tight control of FOXO1 activity is required to maintain the balance between SSC self-renewal and differentiation. Moreover, their studies demonstrated that the transcription factor FOXO1 plays an essential role in the maturation of gonocytes to SSCs via induction of many genes, whose encoded proteins are required for the development and maintenance of SSCs. Our investigation of the sub-cellular localization of 
FOXO1 in postnatal stage showed a clear impairment in the transition of gonocytes to SSCs as judged by retained FOXO1 in cytoplasm of most gonocytes. The phosphorylation of FOXO1 is mediated by PI3K/Akt signaling pathway as shown in Fig. 4.3. In the SSCs, the binding of growth factor GDNF to Ret/Gfral receptor induces the kinase activity of the receptor that phosphorylates and activates PI3K/Akt signaling pathway. The regulation of this pathway is highly important to maintain the balance between self-renewal and differentiation of SSCs. Moreover, GDNF mediated PI3K/Akt signaling pathway is known to play an essential role in SSC self-renewal as its deficiency leads to progressive germ cell loss phenotype (Braydich-Stolle et al., 2007).

Our results showed higher levels of pAkt, the downstream mediator of PI3K, in Pelo-deficient testes compared to that of wild type. The higher phosphorylation of Akt resulted in phosphorylation of FOXO1 and its nuclear export. The higher pAkt levels and retention of FOXO1 in the cytoplasm in inactive form in Pelo mutants suggest that the PI3K/Akt mediated FOXO1 inactivation is highly active in Pelo-deficient germ cells. Our results also coincide with a recent finding by Pederson et al. (2014), where PELO is shown to negatively regulate PI3K signaling pathway in tumor cell lines. According to their analysis, PELO binds to active HER2 and epidermal growth factor receptor and thereby attenuates PI3K/Akt signaling. According to their studies, PELO regulates the Akt signaling likely through regulation of the recruitment of $\mathrm{p} 85-\mathrm{PI} 3 \mathrm{~K}$ to activated receptor and thus Pelo-deficiency results in the induction of PI3K activity.

Consistent with our findings, SSC depletion was also accompanied by a persistent increase in PI3K/Akt activity in mice lacking phosphatase and tensin homolog (PTEN), which normally antagonizes the PI3K/Akt pathway (Goertz et al., 2011). On the other hand, the nuclear retention of FOXO1 in the absence of glucocorticoid-induced leucine zipper (GILZ) resulted in the accumulation of SSCs, as their differentiation potential was impaired ( $\mathrm{Ngo}$ et al., 2013). Although spermatogenesis was successfully initiated in Gilz knockout mice, the progression of spermatogenesis ceased at the pachytene phase of meiosis I.

Hyper-activation of FOXO1, achieved by knocking out 3-phosphoinositide-dependent protein kinase $1(P d k 1)$, was recently reported to increase SSC proliferation and impair SSC differentiation, leading to spermatogenic failure (Goertz et al., 2011). In response to FOXO1 hyper-activation, SSCs were unable to differentiate into spermatogonia and initiate spermatogenesis. The activation of PI3K/Akt signaling pathway results also in high cell 
proliferation, by the expression of cyclin D1, which, promotes the cellular progression through G1 phase (New and Wong, 2007). Analysis of cell cycle and expression of cyclin D1 in Pelo-deficient testes revealed that the high expression of cyclin D1 coincided with active PI3K/Akt signaling pathway. Taken together, our findings showed the hyper-activation of PI3K/Akt signaling in the absence of Pelo. This suggests that the PELO is involved in the regulation of PI3K/Akt pathway in SSCs thereby regulating the self-renewal and differentiation of SSCs.

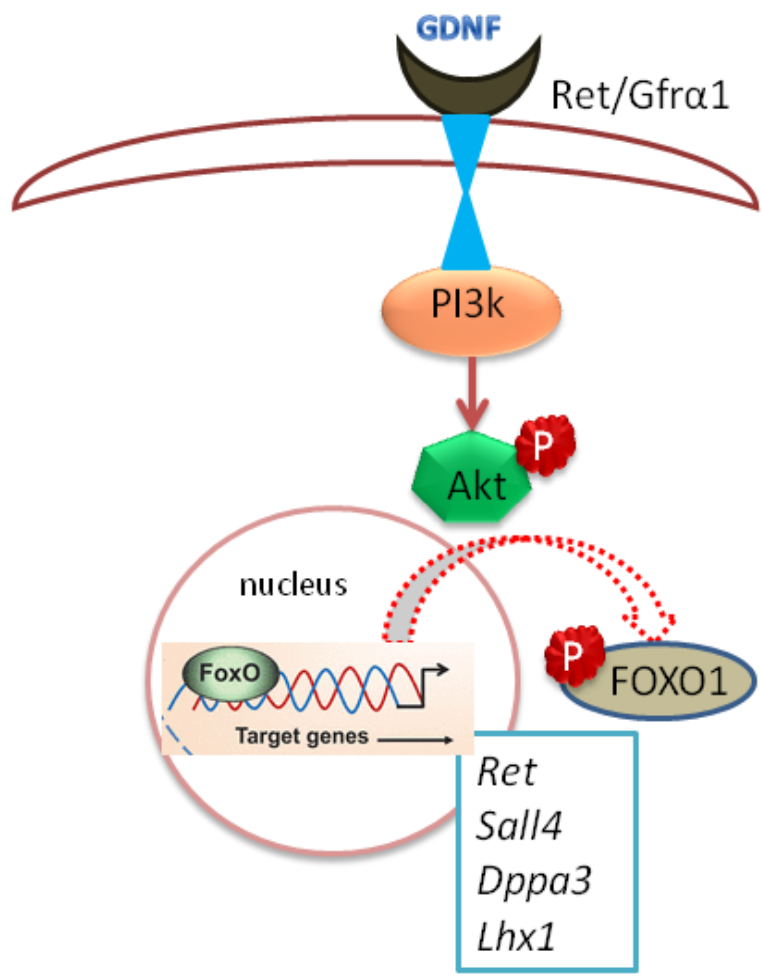

Fig. 4.3. Schematic illustration of PI3K/Akt signaling pathway in SSCs. The tyrosine kinase receptor (Ret/GFR $\alpha 1$ ) in SSCs is activated by growth factor (GDNF). Activated Ret/GFR $\alpha 1$ receptor in turn phosphorylates PI3K in the cytosol. This is followed by the phosphorylation of Akt which phosphorylates the transcription factor, FOXO1. Upon phosphorylation FOXO1 is retained in the cytoplasm and quickly degraded. The nuclear/active FOXO1 is essential for the transcription of genes that regulate the maintenance of SSC such as Ret, Sall4, Dppa3 and Lhxl.

\subsection{Attenuation of BMP signaling in Pelo-deficient ESC impairs the development of extraembryonic endoderm (ExEn)}

It was previously shown that Pelo-deficient embryos die at early post-implantation stage (Adham et al., 2003). Analysis of conditional Pelo knockout mice revealed that the early 
embryonic lethality was a result of impaired development of ExEn. Expression analyses showed that the failure of ExEn differentiation in Pelo-deficient EBs was accompanied by significant decrease in the expression of the transcription factors Gata4, Gata6 and Hnf4, which are markers for ExEn lineage. In contrast, expression of pluripotency-related genes was persistence in Pelo-null EBs. Impaired differentiation of EScs to ExEn in embryoid bodies was shown either by culture of ESCs in medium supplemented with noggin, BMP antagonist or by over-expression of BMPR1b receptor in ESCs (Coucouvanis and Martin, 1999; Conley et al., 2007; Rong et al., 2012). Expression analyses of several BMP ligand genes (Bmp-4 and -6 ) and BMP target genes (IdI and Id3) revealed significant down-regulation of these genes in Pelo-deficient EBs compared with control EBs (Nyamsuren et al., 2014). In contrast, expression of Noggin was up-regulated in the Pelo-deficient EBs.

In frame of my Ph.D study, I participated in the study to determine the BMP activity during the development of ExEn. In this study, I established a BMP responsive reporter cell line $\left(\right.$ Pelo $^{F /-}$ BRE-FFLuc) by stably integrating BMP responsive dual luciferase reporter construct pBFIR (Yadav et al., 2012). EBs were generated from both cell lines and where cultured with or without BMP4. We found that the relative FFLuc activities were increased significantly in BMP4-treated Pelo ${ }^{F /-} B R E-F F L u c$ and Pelo ${ }^{\Delta /-}$ BRE-FFLuc EBs. However, the relative FFLuc activity in control cells was significantly higher than that of mutant cells. Further, relative FFLuc activities were measured in Pelo ${ }^{\mathrm{F} /}$ BRE-FFLuc EBs that were treated for $12 \mathrm{~h}$ either with $\mathrm{Pelo}^{\Delta /-}$ conditioned medium (from mutant $\mathrm{Pelo}^{\Delta /-} \mathrm{EBs}$ ) or with $\mathrm{Pelo}^{\Delta /-}$ conditioned medium and BMP4. We observed that the relative luciferase activity was significantly reduced in control Pelo ${ }^{F /}$ BRE-FFLuc EBs treated with Pelo ${ }^{\Delta /-}$ conditioned medium compared to untreated control. Collectively, these results further confirmed that the mutant $\mathrm{Pelo}^{\Delta /-} \mathrm{EBs}$ produce extracellular modulators of BMP signaling activity.

The significant decrease in the expression levels of BMP targeted genes, phosphorylated Smad1/5, and the over-expression of Noggin in Pelo-deficient EBs suggested that PELO regulates differentiation towards ExEn lineage through the activation of BMP signaling. Further, the negative effect of conditioned medium collected from mutant EBs on the ExEn formation in wild-type EBs and the significant decrease of luciferase activity in the BMP responsive reporter cell line indicated that mutant EBs secreted extracellular modulators, especially the Noggin, which attenuated the BMP signaling activity. 


\subsection{Identification of molecular role of Pelo in mammalian system}

Many biological processes are accomplished by multi-protein complexes, in which one particular protein can be involved in various biological processes and might perform distinct functions. The formation of protein complexes is achieved through interaction with various proteins. Identification of protein-protein interactions is therefore essential to understand the molecular function of any particular protein and its related biological processes. Most human diseases account for the disruption of protein complexes and their functions due to mutations in either a single gene or in many genes (Lim et al., 2006; Lage et al., 2007; Vanunu et al., 2010).

A variety of high throughput methods have been applied in global investigations of the interaction and relationship between two or more proteins. Currently, there are several methods like yeast two-hybrid system ( $\mathrm{Y} 2 \mathrm{H})$, pull-down assay, immunoprecipitation coupled mass spectrometry, stable isotope labeling of amino acids in cells, and targeted releasable affinity probe, which are available to identify the protein-protein interaction networks. Among the available techniques, $\mathrm{Y} 2 \mathrm{H}$ system allows the most cost-effective and genomic-scale screening for protein-protein interactions with the potential to detect weak and transient interactions based on in vivo reporter systems (Fields and Song, 1989; Young, 1998). This approach relies on the activation of downstream reporter genes by the GALA based system (Fields and Song, 1989; Young, 1998), in which the transcriptional activator GAL4 is split into DNA-binding domain (BD) and activation domain (AD) and fused to bait and prey, respectively. The interaction between bait and prey proteins brings the GALA domains into close proximity leading to the transcriptional activation of downstream reporter genes (Fie lds and Song, 1989).

\subsection{Identification of PELO interacting proteins by yeast two-hybrid screening}

In the present study we performed Y2H screening of ESC cDNA library (Zheng et al., 2012) using pGKBT7-Pelo as bait. Following transformation into yeast compe tent cells (Y187) they were plated in medium strigency plate culture (lacking amino acids). The yeast carrying both constructs (encoding interaction protein from the library and pPGKBT7-Pelo) only could grow in these amino acid lacking plates. 
Based on these selection criteria, in the initial screening we identified 243 colonies that had both the bait and prey constructs. Later the colonies were streaked on to plates with $\mathrm{X}-\alpha-\mathrm{Gal}$ and the positive clones that turn blue were selected for sequencing (Fig. 4.4).

A

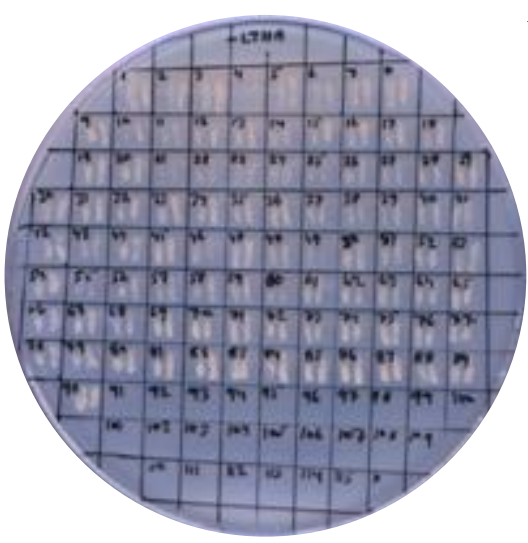

$\mathrm{C}$

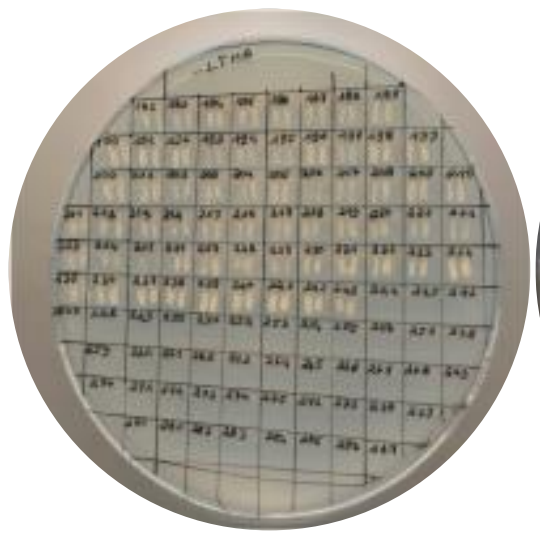

B

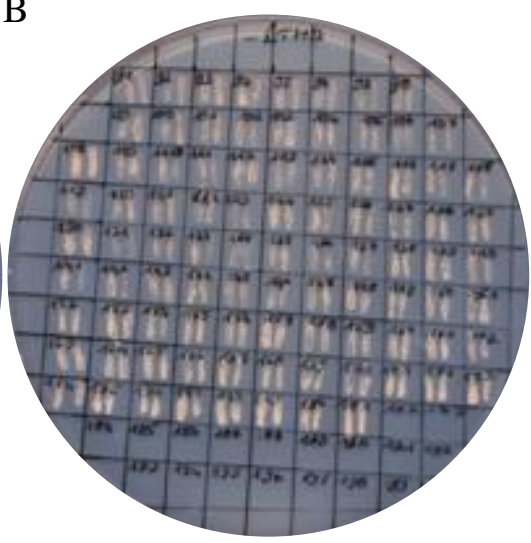

$\mathrm{D}$

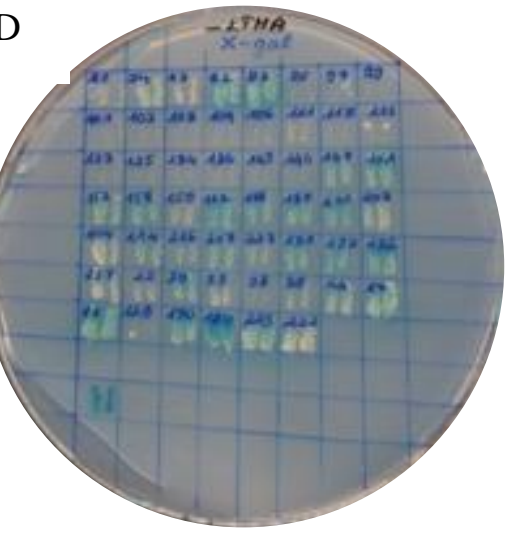

Fig. 4.4. Identification of PELO interaction proteins by Y2H screening of ESC library. The colonies obtained from Y2H streaked onto agar plates lacking essential amino acids (SD/-Leu/-Trp/His/-Ade) at $30^{\circ} \mathrm{C}$ for three days (A-C) and the surviving clones were further selected for the Gal4AD activity by $\mathrm{X}-\alpha-\mathrm{Gal}$ screening (D).

To identify the gene/protein responsible for positive two-hybrid interaction, initially the cDNA insert was rescued and sequenced. Later the sequencing data were analyzed and verified for the presence of open reading frame fused to Gal4 $\mathrm{AD}$ sequence and compared the sequence to those in NCBI database. In order to confirm the interaction between the identified protein and Pelo, direct $\mathrm{Y} 2 \mathrm{H}$ screening was performed. To test the auto-activation or interaction, the prey cDNA clones were co-transformed with either empty pGBK T7 vector or pGBKT7-Pelo into AH109 strain, respectively. The co-transformants were first selected on $\mathrm{SD} /$-Leu/-Trp plates and later tested for the reporter gene expression on SD/-Leu/-Trp/-His/Ade and X- $\alpha$-Gal plates. The surviving clones without autoactivation were identified as putative interaction partners of PELO and characterized further (Fig. 4.5). Based on the direct 
$\mathrm{Y} 2 \mathrm{H}$ results we identified various proteins that are predicted to be interacting with PELO (Table 4.2).

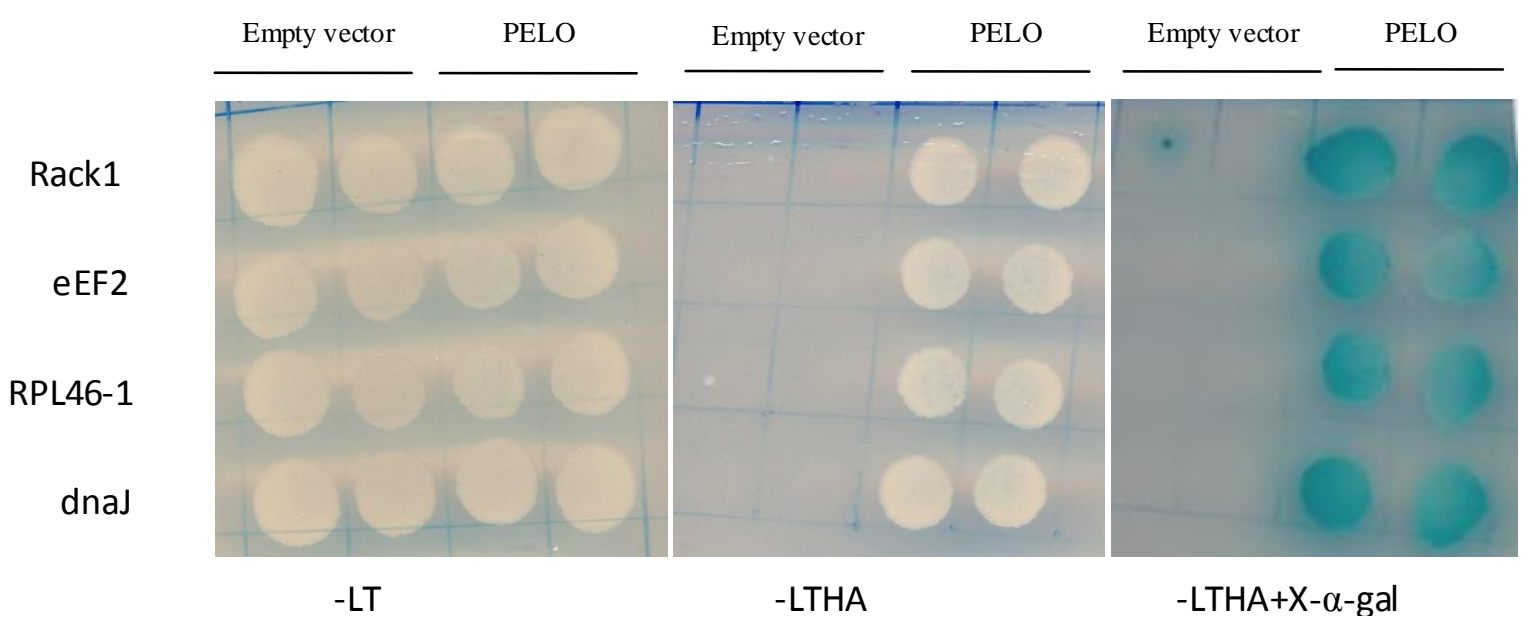

Fig. 4.5. Direct Y2H to confirm the interaction of identified proteins that interact with Pelo. Direct Y2H experiment with prey clones and empty pGKBT7 or pGBKT7-Pelo showing interaction between PELO and RACK1, eEF2, RPL46 and dnaJ homolog assessed by the growth in SD/-Leu/-Trp (-LT), SD/-Leu/-Trp/-His/-Ade (-LTHA) and SD/-Leu/-Trp/-His/-Ade/ X- $\alpha$-Gal (-LTHA+X- $\alpha$-gal) plates.

Table 4.2. Summary of putative interaction proteins of PELO identified by direct Y2H screening.

\begin{tabular}{cc}
\hline No. Of Colonies & Identified interaction partner \\
\hline 13 & 39S ribosomal prote in L46, mitochondrial (RPL46) \\
3 & 40 S ribosomal prote in S23 \\
2 & 60 S ribosomal protein \\
1 & $28 \mathrm{~S}$ ribosomal prote in S 18c \\
1 & 40 S ribosomal protein S7-like \\
3 & protein dnaJ homolog subfamily C member 14 \\
3 & ATP synthase subunit d, mitochondrial \\
1 & ubiquitin fusion degradation protein 1 homolog \\
1 & elongation factor 2(eEF2) \\
1 & receptor for activated C kinase 1 (RACK1) \\
\hline
\end{tabular}




\subsection{Predicted functions of the interaction of Pelo and selected interacting proteins identified in $\mathrm{Y} 2 \mathrm{H}$ screening}

Among the identified proteins receptor for activated C kinase 1 (RACK1), elongation factor 2 (eEF2) and the ribosomal proteins were selected for further analysis because their functions are related to the identified function of PELO. The predicted role of the protein complexes resulting from interaction of PELO with its identified partners can be obtained from characterized function of these proteins, which are summarized as follows.

RACK1, similar to Pelo, is widely expressed during embryonic and adult life and is also subcellularly localized at cytoskeleton (Volta et al., 2013; Osmanagic-Myers and Wiche 2004). Aberrant expression of RACK1 is associated with numerous pathologies including cancer and age related diseases (Battaini et al., 1997). As RACK1 interacts with many proteins, it has been implicated in many fundamental processes like cell growth, proliferation, morphology, movement, death and survival. Similar to Pelo knockout mice, the complete knockout of RACK in mice resulted in early embryonic mortality at gastrulation stage. Apart from this, there was also pigmentation deficit and defects in protein synthesis (Volta et al., 2013). Moreover, RACK1 is also involved in regulation of cell migration, proliferation and invasion capacity of mouse hepatocellular carcinoma cell line (Wu et al., 2013). They also showed the probable involvement of RACK1 in PI3K/Rac1 signaling pathway, which is also interesting as PELO negatively regulates PI3K signaling. Further, RACK1 was recently observed to interact with PI3K p110 alpha by a yeast two-hybrid screening in breast carcinoma cell lines, which was also confirmed by co-immunoprecipitation (Cao et al., 2011). These observations led us to suggest that the interaction between PELO and RACK1 might be involved in the regulation of PI3K/Akt signaling pathway.

The second candidate partner of Pelo is eEF2 identified by direct yeast two-hybrid screening. eEF2 mediates the translocation step during elongation phase of protein translation. eEF2 regulates the transfer of peptidyl-tRNA from A-site of the ribosome to the P-site. eEF2 is phosphorylated and inactivated by a highly specific $\mathrm{Ca}^{2+} /$ calmodulin-dependent kinases (Palfrey, 1983; Redpath et al., 2003). It has been shown previously that the interaction partner of PELO ortholog Dom34, Hbsl shares structural similarity with eEF1 $\alpha$ and eEF3 families (Carr-Schmid et al., 2002). We previously identified that PELO interacts specifically with eIF3G, a subunit of translation initiation factor 3, which plays a central role in translation initiation (Burnicka-Turek et al., 2010) suggesting a possible role of PELO as a translational 
modulator.

Several reports showed that Dom34, the yeast homologue of Pelo, is involved in the No-GO mRNA decay machinery (NGD), which clears cells from mRNA with stalled ribosomes either at stem loop, rare codon or pseudoknot (Chen et al., 2010; Doma and Parker, 2006; Graille et al., 2008). Recently, the conserved role of PELO in quality control mechanisms has been reported in mammalian cells (Saito et al., 2013). In HeLa cells, downregulation of Pelo expression elongates the half-life of fusion $\beta$-globulin mRNA lacking a stop codon. In addition, after knockdown of PELO, expression of $\mathrm{Hbsl}$ and exosome Ski2 that degrades the mRNA was also decreased. These results confirmed that the function of PELO in decay of aberrant mRNA is conserved (Saito et al., 2013). In our group we have also investigated whether PELO is involved in NGD. We studied the expression of transgenic EGFP reporter gene (SL-EGFP), containing a stable stem loop (SL) located upstream in frame with EGFP and a zeocin resistance cassette in Pelo ${ }^{\mathrm{F} /-}$ and Pelo-deficient ESCs. In our study, we could establish zeocin resistant colonies only in case of Pelo-deficient cells but not in Pelo ${ }^{\mathrm{F} /-}$ after selection (Nyamsuren et al., 2014). Accumulation of transgenic SL-EGFP mRNAs in Pelonull ESCs and failure to detect in control Pelo ${ }^{\mathrm{F} /-}$ ESCs led us to suggest that the NGD is responsible to trigger the decay of SL-EGFP mRNA in Pelo $^{\mathrm{F} /}$ ESCs.

In addition, in NGD, Dom34-Hbsl complex may use its dissociation activity to release ribosomes that are stalled for a long time (Tsuboi et al., 2012). Recent reports also have suggested that the Dom34-Hbsl complex mediates dissociation of $40 \mathrm{~S}$ and 60S subunits in a quality control step during ribosomal maturation (Lebaron et al., 2012; Strunk et al., 2012). The identification of several ribosomal proteins, which, were shown to be interacting with PELO in $\mathrm{Y} 2 \mathrm{H}$ screening, lead us to suggest that Pelo and ribosomal protein complex is involved in the characterized role of Pelo in ribosomal recycling.

\subsection{Conclusion and perspectives}

Taken together our study has shown that Pelo is essential for the germ cell development and for the regulation of SSCs. We have shown evidence that PELO indirectly regulates the subcellular localization of FOXO1, as PI3K/Akt signaling is highly activated in the absence of PELO. This in turn affects SSC pool formation, disrupts the balance between SSC selfrenewal and differentiation, and contributes to a loss of spermatogenesis. Thus, PELO is essential for finely regulating the signals required for the maintenance of SSC pool. In order 
to know if the signaling from the Sertoli cells to SSCs is affected, Pelo-deficient SSCs can be transplanted in testes of busulfan treated wild-type mice. It has been shown that Pelo competes with the p85 subunit of PI3K to bind with the receptors in cancer cell lines. In order to prove that Pelo regulates the PI3K/Akt signaling by competitive binding to the RET/GFR $\alpha 1$ receptor in SSCs, co-immunoprecipitation and GST pull-down assays could be performed. It would be also interesting to follow up with the identified interaction proteins of PELO which will enumerate the putative roles of PELO in mammals. Many recent reports have shown that PELO ortholog Dom34 has a role in protein translation, in particular the ribosome recycling. Although the function of PELO in translational regulation has been extensively characterized in yeast, only little is known in mammalian system. Moreover, the interaction of PELO with eEF2 identified in our Y2H screening might help in identifying the role of PELO in translation. Therefore, it would be of great importance to determine the recruitment of mammalian PELO to translational elongation complex and the associated translational regulation mechanisms. Extending the study on role of Pelo in female fertility of mouse would add valuable information about the overall role of PELO in maintenance of fertility in mouse. 


\section{REFERENCES}

Adham IM, Sallam MA, Steding G, Korabiowska M, Brinck U, Hoyer-Fender S, Oh C, Engel W. Disruption of the pelota gene causes early embryonic lethality and defects in cell cycle progression. Mol Cell Biol 2003, 23:1470-1476.

Baldin V, Lukas J, Marcote MJ, Pagano M, Draetta G. Cyclin D1 is a nuclear protein required for cell cycle progression in G1. Genes Dev 1993, 7:812-821.

Battaini F, Pascale A, Paoletti R, Govoni S. The role of anchoring protein RACK1 in PKC activation in the ageing rat brain. Trends Neurosci 1997, 20:410-415.

Bellve AR, Cavicchia JC, Millette CF, O'Brien DA, Bhatnagar YM, Dym M. Spermatogenic cells of the prepuberal mouse. Isolation and morphological characterization. J Cell Biol 1977, 74:68-85.

Braydich-Stolle L, Kostereva N, Dym M, Hofmann MC. Role of Src family kinases and N-Myc in spermatogonial stem cell proliferation. Dev Biol 2007, 304:34-45.

Brunet A, Bonni A, Zigmond MJ, Lin MZ, Juo P, Hu LS, Anderson MJ, Arden KC, Blenis J, Greenberg ME. Akt promotes cell survival by phosphorylating and inhibiting a Forkhead transcription factor. Cell 1999, 96:857-868.

Buaas FW, Kirsh AL, Sharma M, McLean DJ, Morris JL, Griswold MD, de Rooij DG, Bra un RE. Plzf is required in adult male germ cells for stem cell self-renewal. Nat Genet 2004, 36:647-652.

Bult CJ, White O, Olsen GJ, Zhou L, Fleischmann RD, Sutton GG, Blake JA, FitzGerald LM, Clayton RA, Gocayne JD, et al. Complete genome sequence of the methanogenic archaeon, Methanococcus jannaschii. Science 1996, 273 :1058-1073.

Burnicka-Turek O, Kata A, Buyandelger B, Ebermann L, Kramann N, Burfeind P, HoyerFender S, Engel W, Adham IM. Pelota interacts with HAX1, EIF3G and SRPX and the resulting protein complexes are associated with the actin cytoskeleton. BMC Cell Biol 2010, 11:28.

Cao XX, Xu JD, Xu JW, Liu XL, Cheng YY, Li QQ, Xu ZD, Liu XP. RACK1 promotes breast carcinoma migration/metastasis via activation of the RhoA/Rho kinase pathway. Breast Cancer Res Treat 2011, 126:555-563.

Carr-Schmid A, Pfund C, Craig EA, Kinzy TG. Novel G-protein complex whose requirement is linked to the translational status of the cell. Mol Cell Biol 2002, 22:2564-2574.

Castrillon DH, Gonczy P, Alexander S, Rawson R, Eberhart CG, Viswanathan S, DiNardo S, Wasserman SA. Toward a molecular genetic analysis of spermatogenesis in Drosophila melanogaster: characterization of male-sterile mutants generated by single $\mathrm{P}$ element mutagenesis. Genetics 1993, 135:489-505.

Chan F, Oatley MJ, Kaucher AV, Yang QE, Bieberich CJ, Shashikant CS, Oatley JM. Functional and molecular features of the Id4+ germline stem cell population in mouse testes. Genes Dev 2014, 28:1351-1362. 
Chen C, Ouyang W, Grigura V, Zhou Q, Carnes K, Lim H, Zhao GQ, Arber S, Kurpios N, Murphy TL, et al. ERM is required for transcriptional control of the spermatogonial stem cell niche. Nature 2005, 436:1030-1034.

Chen L, Muhlrad D, Hauryliuk V, Cheng Z, Lim MK, Shyp V, Parker R, Song H. Structure of the Dom34-Hbs1 complex and implications for no-go decay. Nat Struct Mol Biol 2010, 17:1233-1240.

Conley BJ, Ellis S, Gulluyan L, Mollard R. BMPs regulate differentiation of a putative visceral endoderm layer within human embryonic stem-cell-derived embryoid bodies. Biochem Cell Biol 2007, 85:121-132.

Costoya JA, Hobbs RM, Barna M, Cattoretti G, Manova K, Sukhwani M, Orwig KE, Wolgemuth DJ, Pandolfi PP. Essential role of Plzf in maintenance of spermatogonial stem cells. Nat Genet 2004, 36:653-659.

Coucouvanis E, Martin GR. BMP signaling plays a role in visceral endoderm differentiation and cavitation in the early mouse embryo. Development 1999, 126:535-546.

Culty M. Gonocytes, the forgotten cells of the germ cell lineage. Birth Defects Res C Embryo Today 2009, 87:1-26.

Davis L, Engebrecht J. Yeast dom34 mutants are defective in multiple developmental pathways and exhibit decreased levels of polyribosomes. Genetics 1998, 149:45-56.

de Rooij DG. Stem cells in the testis. Int J Exp Pathol 1998, 79:67-80.

Doma MK, Parker R. Endonucleolytic cleavage of eukaryotic mRNAs with stalls in translation elongation. Nature 2006, 440:561-564.

Eberhart CG, Wasserman SA. The pelota locus encodes a protein required for meiotic cell division: an analysis of G2/M arrest in Drosophila spermatogenesis. Development 1995, 121:3477-3486.

Fields S, Song O. A novel genetic system to detect protein-protein interactions. Nature 1989, 340:245-246.

Frolova L, Le Goff X, Rasmussen HH, Cheperegin S, Drugeon G, Kress M, Arman I, Haenni AL, Celis JE, Philippe M, et al. A highly conserved eukaryotic protein family possessing properties of polypeptide chain release factor. Nature 1994, 372:701-703.

Gandhi R, Manzoor M, Hudak KA. Depurination of Brome mosaic virus RNA3 in vivo results in translation-dependent accelerated degradation of the viral RNA. J Biol Chem 2008, 283:32218-32228.

Goertz MJ, Wu Z, Gallardo TD, Hamra FK, Castrillon DH. Foxo1 is required in mouse spermatogonial stem cells for their maintenance and the initiation of spermatogenesis. $J$ Clin Invest 2011, 121:3456-3466.

Graille M, Chaillet M, van Tilbeurgh H. Structure of yeast Dom34: a protein related to translation termination factor Erfl and involved in No-Go decay. J Biol Chem 2008, 283:7145-7154. 
Handel MA, Cobb J and Eaker S. What are the spermatocyte's requirements for successful meiotic division? J. Exp. Zool. 1999, 285:243-250.

Jonsson H, Allen P, Peng SL. Inflammatory arthritis requires Foxo3a to prevent Fas ligand-induced neutrophil apoptosis. Nat Med 2005, $11: 666-671$.

Kanatsu-Shinohara M, Shinohara T. Spermatogonial stem cell self-renewal and development. Annu Rev Cell Dev Biol 2013, 29:163-187.

Kobayashi K, Kikuno I, Kuroha K, Saito K, Ito K, Ishitani R, Inada T, Nureki O. Structural basis for mRNA surveillance by archaeal Pelota and GTP-bound EF1alpha complex. Proc Natl Acad Sci U S A 2010, 107:17575-17579.

Kops GJ, de Ruiter ND, De Vries-Smits AM, Powell DR, Bos JL, Burgering BM. Direct control of the Forkhead transcription factor AFX by protein kinase B. Nature 1999, 398:630634.

Lage K, Karlberg EO, Storling ZM, Olason PI, Pedersen AG, Rigina O, Hinsby AM, Tumer Z, Pociot F, Tommerup N, et al. A human phenome-interactome network of protein complexes implicated in genetic disorders. Nat Biotechnol 2007, 25:309-316.

Lalo D, Stettler S, Mariotte S, Gendreau E, Thuriaux P. Organization of the centromeric region of chromosome XIV in Saccharomyces cere visiae. Yeast 1994, 10:523-533.

Lebaron S, Schneider C, van Nues RW, Swiatkowska A, Walsh D, Bottcher B, Granneman S, Watkins NJ, Tollervey D. Proofreading of pre-40S ribosome maturation by a translation initiation factor and 60S subunits. Nat Struct Mol Biol 2012, 19:744-753.

Lee HH, Kim YS, Kim KH, Heo I, Kim SK, Kim O, Kim HK, Yoon JY, Kim HS, Kim do J, et al. Structural and functional insights into Dom34, a key component of no-go mRNA decay. Mol Cell 2007, 27:938-950.

Lim U, Subar AF, Mouw T, Hartge P, Morton LM, Stolzenberg-Solomon R, Campbell D, Hollenbeck AR, Schatzkin A. Consumption of aspartame-containing beverages and incidence of hematopoietic and brain malignancies. Cancer Epidemiol Biomarkers Prev 2006, 15:1654-1659.

Meng X, Lindahl M, Hyvonen ME, Parvinen M, de Rooij DG, Hess MW, Raatikainen-Ahokas A, Sainio K, Rauvala H, Lakso M, et al. Regulation of cell fate decision of undifferentiated spermatogonia by GDNF. Science 2000, 287:1489-1493.

Morrow CM, Hostetler CE, Griswold MD, Hofmann MC, Murphy KM, Cooke PS, Hess RA. ETV5 is required for continuous spermatogenesis in adult mice and may mediate blood testes barrier function and testicular immune privilege. Ann N Y Acad Sci 2007, 1120:144-151.

Naughton CK, Jain S, Strickland AM, Gupta A, Milbrandt J. Glial cell-line derived neurotrophic factor-mediated RET signaling regulates spermatogonial stem cell fate. Biol Reprod 2006, 74:314-321.

New DC and Wong YH. Molecular mechanisms mediating the G protein-coupled receptor regulation of cell cycle progression. Journal of Mol. Signaling, 2007, 2:2. 
Ngo D, Cheng Q, O'Connor AE, DeBoer KD, Lo CY, Beaulieu E, De Seram M, Hobbs RM, O'Bryan MK, Morand EF. Glucocorticoid-induced leucine zipper (GILZ) regulates testicular FOXO1 activity and spermatogonial stem cell (SSC) function. PLoS One 2013, 8:e59149.

Nyamsuren G, Kata A, Xu X, Raju P, Dressel R, Engel W, Pantakani DV, Adham IM. Pelota regulates the development of extraembryonic endoderm through activation of bone morphogenetic protein (BMP) signaling. Stem Cell Res 2014, 13:61-74.

Osmanagic-Myers S, Wiche G. Plectin-RACK1 (receptor for activated C kinase 1) scaffolding: a novel mechanism to regulate protein kinase C activity. J Biol Chem 2004, 279:1870118710.

Palfrey HC. Presence in many mammalian tissues of an identical major cytosolic substrate (Mr 100 000) for calmodulin-dependent protein kinase. FEBS Lett 1983, 157:183-190.

Passos DO, Doma MK, Shoemaker CJ, Muhlrad D, Green R, Weissman J, Hollien J, Parker R. Analysis of Dom34 and its function in no-go decay. Mol Biol Cell 2009, 20:3025-3032.

Payne CJ, Gallagher SJ, Foreman O, Dannenberg JH, Depinho RA, Braun RE. Sin3a is required by sertoli cells to establish a niche for undifferentiated spermatogonia, germ cell tumors, and spermatid elongation. Stem Cells 2010, 28:1424-1434.

Pedersen K, Canals F, Prat A, Tabernero J, Arribas J. PELO negatively regulates HER receptor signalling and metastasis. Oncogene 2014, 33:1190-1197.

Phillips BT, Gassei K, Orwig KE. Spermatogonial stem cell regulation and spermatogenesis. Philos Trans R Soc Lond B Biol Sci 2010, 365:1663-1678.

Puri P, Phillips BT, Suzuki H, Orwig KE, Rajkovic A, Lapinski PE, King PD, Feng GS, Walker WH. The transition from stem cell to progenitor spermatogonia and male fertility requires the SHP2 protein tyrosine phosphatase. Stem Cells 2014, 32:741-753.

Ragan MA, Logsdon JM, Jr., Sensen CW, Charlebois RL, Doolittle WF. An archaebacterial homolog of pelota, a meiotic cell division protein in eukaryotes. FEMS Microbiol Lett 1996, 144:151-155.

Redpath NT, Foulstone EJ and Proud CG. Regulation of translation elongation factor-2 by insulin via a rapamycin-sensitive signalling pathway. EMBO J. 2003 1;15(9):2291-7.

Rong L, Liu J, Qi Y, Graham AM, Parmacek MS, Li S. GATA-6 promotes cell survival by upregulating BMP-2 expression during embryonic stem cell differentiation. Mol Biol Cell 2012, 23:3754-3763.

Saito S, Hosoda N, Hoshino S. The Hbs1-Dom34 protein complex functions in non-stop mRNA decay in mammalian cells. J Biol Chem 2013, 288:17832-17843.

Schlesser HN, Simon L, Hofmann MC, Murphy KM, Murphy T, Hess RA, Cooke PS. Effects of ETV5 (ets variant gene 5) on testis and body growth, time course of spermatogonial stem cell loss, and fertility in mice. Biol Reprod 2008, 78:483-489. 
Schrans-Stassen BH, Saunders PT, Cooke HJ, de Rooij DG. Nature of the spermatogenic arrest in Dazl -/- mice. Biol Reprod 2001, 65:771-776.

Shamsadin R, Adham IM, Engel W. Mouse pelota gene (Pelo): cDNA cloning, genomic structure, and chromosomal localization. Cytogenet Genome Res 2002, 97:95-99.

Shamsadin R, Adham IM, von Beust G, Engel W. Molecular cloning, expression and chromosome location of the human pelota gene PELO. Cytogenet Cell Genet 2000, 90:75-78.

Simon L, Ekman GC, Tyagi G, Hess RA, Murphy KM, Cooke PS. Common and distinct factors regulate expression of mRNA for ETV5 and GDNF, Sertoli cell proteins essential for spermatogonial stem cell maintenance. Exp Cell Res 2007, 313:3090-3099.

Song X, Wong MD, Kawase E, Xi R, Ding BC, McCarthy JJ, Xie T. Bmp signals from niche cells directly repress transcription of a differentiation-promoting gene, bag of marbles, in germline stem cells in the Drosophila ovary. Development 2004, 131:1353-1364.

Spradling A, Drummond-Barbosa D, Kai T. Stem cells find their niche. Nature 2004, 414:98104.

Strunk BS, Novak MN, Young CL, Karbstein K. A translation-like cycle is a quality control checkpoint for maturing 40S ribosome subunits. Cell 2012, 150:111-121.

Suzuki H, Sada A, Yoshida S, Saga Y. The heterogeneity of spermatogonia is revealed by their topology and expression of marker proteins including the germ cell-specific proteins Nanos2 and Nanos3. Dev Biol 2009, 336:222-231.

Tokuda M, Kadokawa Y, Kurahashi H, Marunouchi T. CDH1 is a specific marker for undifferentiated spermatogonia in mouse testes. Biol Reprod 2007, 76:130-141.

Tsuboi T, Kuroha K, Kudo K, Makino S, Inoue E, Kashima I, Inada T. Dom34:hbs1 plays a general role in quality-control systems by dissociation of a stalled ribosome at the 3 ' end of aberrant mRNA. Mol Cell 2012, 46:518-529.

Vanunu O, Magger O, Ruppin E, Shlomi T, Sharan R. Associating genes and protein complexes with disease via network propagation. PLoS Comput Biol 2010, 6:e1000641.

Volta V, Beugnet A, Gallo S, Magri L, Brina D, Pesce E, Calamita P, Sanvito F, Biffo S. RACK1 depletion in a mouse model causes lethality, pigmentation deficits and reduction in protein synthesis efficiency. Cell Mol Life Sci 2013, 70:1439-1450.

Wu J, Meng J, Du Y, Huang Y, Jin Y, Zhang J, Wang B, Zhang Y, Sun M, Tang J. RACK1 promotes the proliferation, migration and invasion capacity of mouse hepatocellular carcinoma cell line in vitro probably by PI3K/Rac1 signaling pathway. Biomed Pharmacother 2013, 67:313-319.

Wu X, He WT, Tian S, Meng D, Li Y, Chen W, Li L, Tian L, Zhong CQ, Han F, et al. pelo is required for high efficiency viral replication. PLoS Pathog 2014, 10:e1004034.

Xi R, Doan C, Liu D, Xie T. Pelota controls self-renewal of germline stem cells by repressing a Bam-independent differentiation pathway. Development 2005, 132:5365-5374. 
Xie T, Spradling AC. decapentaplegic is essential for the maintenance and division of germline stem cells in the Drosophila ovary. Cell 1998, 94:251-260.

Xie T, Spradling AC. A niche maintaining germ line stem cells in the Drosophila ovary. Science 2000, 290:328-330.

Yadav PS, Prashar P, Bandyopadhyay A. BRITER: a BMP responsive osteoblast reporter cell line. PLoS One 2012, 7 :e37134.

Yoshida S, Sukeno M, Nakagawa T, Ohbo K, Nagamatsu G, Suda T, Nabeshima Y. The first round of mouse spermatogenesis is a distinctive program that lacks the self-renewing spermatogonia stage. Development 2006, 133:1495-1505.

Yoshida S, Takakura A, Ohbo K, Abe K, Wakabayashi J, Yamamoto M, Suda T, Nabeshima Y. Neurogenin3 delineates the earliest stages of spermatogenesis in the mouse testis. Dev Biol 2004, 269:447-458.

Young KH. Yeast two-hybrid: so many interactions, (in) so little time. Biol Reprod 1998, 58:302-311.

Zheng Y, Tan X, Pyczek J, Nolte J, Pantakani DV, Engel W. Generation and characterization of yeast two-hybrid cDNA libraries derived from two distinct mouse pluripotent cell types. Mol Biotechnol 2012, 54:228-237.

Zogbi C, Tesser RB, Encinas G, Miraglia SM, Stumpp T. Gonocyte development in rats: proliferation, distribution and death revisited. Histochem Cell Biol 2012, 138:305-322. 


\section{ACKNOWLEDGEMENTS}

I am nothing but thankful for the opportunity to learn and do my $\mathrm{PhD}$ in this institute. I have learned a lot about the work, lab culture, management and organization during my time here. I have met people whom I will remember for the rest of my days for giving me the valuable lessons, both good and bad. I am also grateful for the ICAR organization for the fellowship to pursue my studies abroad.

Above all, I want to sincerely thank Prof. Dr. med. Dr. h. c. Wolfgang Engel for being an important influence in my career. He had been the motivation for many of my research ideas and always invokes new ideas. I have a great respect for him and I am ever thankful for he chose to guide me throughout my $\mathrm{PhD}$ despite his health and retirement.

I am thankful to Prof. Brenig for his kind gesture and to have motivated me by the way he responded after my every progress report presentation. His encouraging words had helped me in ways he does not know to work more and hard. I also thank him for the discussions and suggestions.

My heartfelt gratitude to Prof. Ibrahim M. Adham for his patience with me and to have guided me until the end. He had been a wonderful supervisor who spent endless hours to design the experiments, interpretation of results and to read a countless number of articles to help me with my study. He had always found time for me and was available for discussions. I am forever grateful to him.

I am indebted to Dr. Krishna Pantakani and Dr. L. Smorag for their suggestions and discussions about my work. I am also thankful to Dr. Krishna Pantakani for helping me with correcting my manuscripts and taught me the yeast two hybrid experiments.

My sincere thanks to Nadine Mellies, for her kindness and thoughtfulness in helping others. She had been helping me whenever I felt low at work and always gave me encouraging words. I have my special thanks to my lab mates Dr. Gunsmaa Nyamsuren and Christian Müller for the help rendered in the lab. I am thankful to Gunjee for her help in my work as much as she can. I thank Christian very much for helping me with my German difficulties. I also thank all my institute colleagues and lab mates Dr. Manar Elkenani, Sidra Shahid, Luisa Freese, Johanna Manz and Johanna Jacubizka for all the support. I am thankful to my dear friend Dr. Suresh Gaikwad who had changed my life for better by teaching me the positive 
outlook of life. I am also grateful to Jean Phillipe Boesinger who had won my heart by being patient and loving throughout. I am also thankful to my family who had been supporting in all my endeavors throughout my life. 


\section{CURRICULUM VITAE}

\section{Personal details:}

Name: $\quad$ Priyadharsini Raju

Date of birth: $\quad 28.11 .1981$

Place of birth: $\quad$ TamilNadu, India

Nationality: $\quad$ Indian

Address: $\quad$ Max-Kade Haus 16, Rodererstrasse 15, Göttingen

Email: $\quad$ priyavet11@ gmail.com

\section{Education:}

1992-1999

Higher secondary school (TamilNadu, India)

$1999-2005$

Bachelor of Veterinary science (TamilNadu, India)

2006-2009

Masters in Animal Gynaecology and Obstetrics (TamilNadu, India)

Since June, 2012

$\mathrm{PhD}$ study in the Institute of Human Genetics, Georg-August University

Göttingen, Germany

\section{Professional experience:}

2010-present: $\quad$ Scientist, CIRG, UP, India

2009: $\quad$ Senior Research Fellow, NIANP, Bangalore, India

2005 -2007: $\quad$ Clinician in VKS veterinary clinic, Chennai, India 


\section{LIST OF PUBLICATIONS}

1. Sellappan S, Priyadarshini R, Rao SBN, Raghavendra S, Nandi S, Dineshkumar D, Thayakumar A, Parthipan S and Ravindra JP. 2012. Evaluation of maize grain and polyunsaturated fatty acid (PUFA) as energy sources for breeding rams based on hormonal, sperm functional parameters and fertility. Reproduction, Fertility and Development. http://dx.doi.org/10.1071/RD11229

2. Selvaraju S, Raghavendra BS, Siva Subramani T, Priyadharsini R, Reddy IJ, Ravindra JP. 2010. Changes in luteal cells distribution, apoptotic rate, lipid peroxidation levels and antioxidant enzyme activities in buffalo (Bubalus bubalis) corpus luteum. Animal Reproduction Science 120: $39-46$.

3. Selvaraju S, Sivasubramani T, Raghavendra BS, Raju P, Rao SBN, Dineshkumar D, Ravindra JP. Effect of dietary energy on seminal plasma insulin-like growth factor-I (IGF-1) and testosterone levels, semen quality and fertility in adult rams. Theriogenology 78: 646-655

4. Priyadharsini R., Jindal S. K., Sharma D., Ramachandran N., Karche S.D. and Goel A.K. 2011. Effect of Different Egg Yolk Level on the Cryopreservation Capability of Jakhrana Goat Semen. J Anim Sci Adv, 1(1): 28-37

5. Gunsmaa Nyamsuren, Aleksandra Kata, Xingbo Xu, Priyadharsini Raju, Ralf Dressel, Wolfgang Engel, D.V. Krishna Pantakani, Ibrahim M. Adham (2014): Pelota regulates the development of extraembryonic endoderm through activation of bone morphogenetic prote in (BMP) signaling. Stem Cell Research, 13, 61-74.

6. Priyadharsini Raju, Gunsmaa Nyamsuren, Aleksandra Kata, Manar Elkenani, Wolfgang Engel, Ibrahim M. Adham (2015): Pelota mediates gonocyte maturation and maintenance of spermatogonial stem cells in mouse testes. Reproduction, 149:213-221.

7. Manar Elkenani, Gunsmaa Nyamsuren, Priyadharsini Raju, Kifayathullah Liakath-Ali, Aisha Hamdaoui, A lexandra Kata, Ralf Dressel, Thomas Klonisch, Fiona M. Watt, Wolfgang Engel, Krishna Pantakani, Ibrahim M. Adham. Pelota regulates epidermal barrier acquisition through profilaggrin-to-filaggrin processing. Manuscript ready for submission to Journal of investigative dermatology. 